San Jose State University

SJSU ScholarWorks

Master's Theses

Master's Theses and Graduate Research

1991

\title{
Erosional processes in a portion of the Hollister Hills State Vehicular Recreational Area, California
}

Brian Taylor

San Jose State University

Follow this and additional works at: https://scholarworks.sjsu.edu/etd_theses

\section{Recommended Citation}

Taylor, Brian, "Erosional processes in a portion of the Hollister Hills State Vehicular Recreational Area, California" (1991). Master's Theses. 170.

DOI: https://doi.org/10.31979/etd.hzm4-b2jc

https://scholarworks.sjsu.edu/etd_theses/170

This Thesis is brought to you for free and open access by the Master's Theses and Graduate Research at SJSU ScholarWorks. It has been accepted for inclusion in Master's Theses by an authorized administrator of SJSU ScholarWorks. For more information, please contact scholarworks@sjsu.edu. 


\section{INFORMATION TO USERS}

This manuscript has been reproduced from the microfilm master. UMI films the text directly from the original or copy submitted. Thus, some thesis and dissertation copies are in typewriter face, while others may be from any type of computer printer.

The quality of this reproduction is dependent upon the quality of the copy submitted. Broken or indistinct print, colored or poor quality illustrations and photographs, print bleedthrough, substandard margins, and improper aligniment can adversely affect reproduction.

In the unlikely event that the author did not send UMI a complete manuscript and there are missing pages, these will be noted. Also, if unauthorized copyright material had to be removed, a note will indicate the deletion.

Oversize materials (e.g., maps, drawings, charts) are reproduced by sectioning the original, beginning at the upper left-hand corner and continuing from left to right in equal sections with small overlaps. Each original is also photographed in one exposure and is included in reduced form at the back of the book.

Photographs included in the original manuscript have been reproduced xerographically in this copy. Higher quality $6 " \times 9$ " black and white photographic prints are available for any photographs or illustrations appearing in this copy for an additional charge. Contact UMI directly to order.

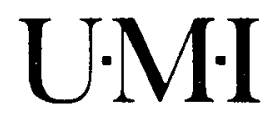

University Microfilms International

A Bell \& Howell information Company

300 North Zeeb Road. Ann Arbor. MI 48106-1346 USA

313/761-4700 800:521.0600 
Erosional processes in a portion of the Hollister Hills State Vehicular Recreational Area, California

Taylor, Brian E., M.S.

San Jose State University, 1991 


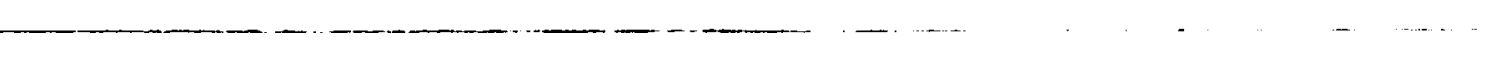




\title{
EROSIONAL PROCESSES IN A PORTION OF THE HOLLISTER HILLS STATE VEHICULAR RECREATIONAL AREA, CALIFORNIA
}

\author{
A Thesis \\ Presented to \\ The Faculty of the Department of Geology \\ San Jose State University \\ In Partial Fulfillment \\ of the Requirements for the Degree \\ Master of Science
}

\author{
By \\ Brian Taylor \\ May, 1991
}


APPROVED FOR THE DEPARTMENT OF GEOLOGY

bharal harden

Dr. Deborah R. Harden

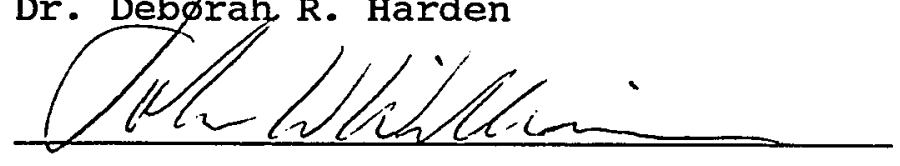

Dr. John W. Williams

Manhole Haddock

Dr. Marshall Maddock

APPROVED FOR THE UNIVERSITY

Yaren gt. Stanfore 


\section{ACKNOWLEDGEMENTS}

The author gratefully acknowledges the many people who contributed to the success of this thesis. Committee chairperson Dr. D. Harden provided invaluable guidance and obtained funding from Dr. R. Woodward of the California Department of Parks and Recreation for this thesis. Committee members Dr. J. Williams and Dr. M. Maddock of the San Jose State University critically reviewed the manuscript. Mr. Thomas Rogers of Woodward-Clyde Consultants and personnel of the California Division of Mines and Geology willing supplied Rogers' unpublished geologic maps.

Appreciation is extended to San Jose State University Geology Department office administrator Isabelle copeland and Geology Department technician Dennis Fox, who supported me with essential technical assistance. Special thanks to my friend, Julia Slocombe, who provided unwavering moral support, and to Rexford Upp, who unselfishly allowed me the use of his office for the completion of this thesis. 


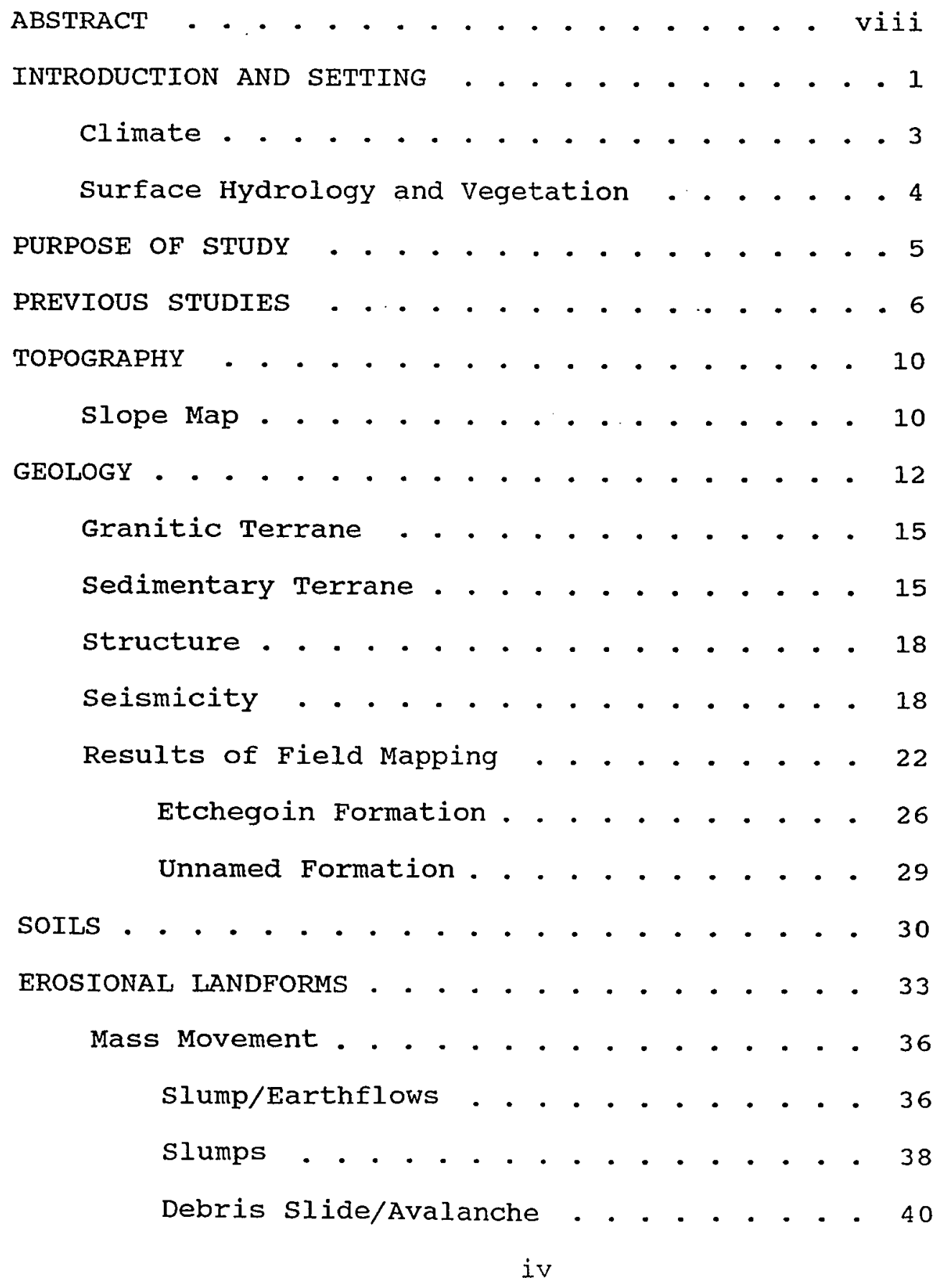


Rock Fall.............. . . 44

Fluvial Erosion . . . . . . . . . . . 45

Piping . . . . . . . . . . . . 45

Gullying . . . . . . . . . . . . 49

INFLUENCE OF PHYSICAL PARAMETERS . . . . . . . 51

Historic Causes . . . . . . . . . . 51

Triggering Mechanisms . . . . . . . . . 59

INFILTROMETER RATES . . . . . . . . . . . 62

DISTRIBUTION OF EROSIONAL LANDFORMS . • • • • • 72

SUMMARY AND CONCLUSIONS . . . . . . . . . . 74

RECOMMENDATIONS FOR FURTHER STUDY . • • • • • 77

REFERENCES CITED • • . . . . . . . . . . . . 79

LIST OF AERIAL PHOTOS . . . . . . . . . . . . . 83

APPENDIX A - Field Invesitigation . . . . . . 84

APPENDIX B - Infiltrometer Data . . . . . . . 95 


\section{LIST OF IIIUSTRATIONS}

Figure

Page

1. Location map . . . . . . . . . . . . 2

2. Aerial photograph of San Andreas Fault . . 14

3. Bay area seismicity . . . . . . . . . 20

4. Geologic map of study area . . . . . . . 21

5. Soil stripped to bedrock on Drag Hill . . . . 22

6. Cross section of sedimentary terrane . . . . 24

7. Outcrop on Backridge Road . . . . . . . . 25

8. Location map of study area . . . . . . . 27

9. Distribution of soils in the study area . . 31

10. Active Cienega Road slump/earthflow . . . 40

11. Active debris slide on western boundary of study area.. . . . . . . . . . . . 4 42

12. Piping at Tank and Middlefield roads . . . 47

13. Downslope end of pipe shown in Fig. 12 . . 48

14. Piping above Turtle Lake . . . . . . . . 49

15. Percentage of slides on various slopes . . 53

16. Renz gully . . . . . . . . . . . . 58

17. Infiltrometer . . . . . . . . . . 63

18. Schematic diagram of infiltrometer . . . . 65

19. Infiltrometer test locations . . . . . . 68 


\section{LIST OF TABLES}

Table

Page

1. Percentage of study area underlain by slopes of various steepness . . . . . . 11

2. Distribution of active and inactive landslides . . . . . . . . . . . 54

3. Example of infiltration results . . . . . 66

4. Summary of infiltrometer results . . . . . 67

5. Percent of active features in area . . . . 73

Plates

Plate 1: Landslide map.

Plate 2: Slope map. 
ABSTRACT

Hollister Hills state Recreational Vehicular Area (HHSVRA), located in the Gabilan Range in central California, is operated by the California Department of Parks and Recreation and utilized by off-road vehicles. Planned expansion of HHSVRA to the adjacent Renz acquisition created the need for baseline erosional landform data in the area.

Previous studies indicate that off-road vehicles (ORVs) change physical and chemical soil properties, thus accelerating fluvial erosion. Ten paired on-trail and offtrail infiltrometer tests were done to quantify the reduction in infiltration on the ORV trails. The average on-trail infiltration rate was $4.93 \mathrm{~cm} / \mathrm{hr}$, and the average off-trail infiltration rate was $180 \mathrm{~cm} / \mathrm{hr}$.

Preliminary results from this study indicate that active erosional landforms are less common on ORV-impacted slopes in HHSVRA than on pristine slopes in the Renz acquisition. Accelerated erosion from motorcycle traffic has not significantly affected the distribution of large erosional landforms. This suggests that storms, geology, slope steepness, and grazing activity are more important factors influencing erosion in the study area. 
The Hollister Hills State Vehicular Recreational Area (HHSVRA) is a $9.7 \mathrm{~km}^{2}(2,400$ acre) unit of the california State Park System located $20.7 \mathrm{~km}$ ( 8 miles) south of Hollister, California (fig. 1). HHSVRA offers off-road recreation for motorcyclists, 4-wheelers, picnickers, and campers. Visitor attendance at HHSVRA increased from 33,202 in 1980 to 98,153 in 1988 (Harvey, H.T and Associates, 1989). Increased ridership precipitated the acquisition in 1989 of two adjacent ranches, Hudner Ranch, which lies southeast of the active Lower Ranch, and the $6.88 \mathrm{~km}^{2}(1,700$ acre) Renz acquisition to the northwest. Located in the Gabilan Range, the study area includes the $2 \mathrm{~km}^{2}$ (495 acre) eastern parcel, of the Lower Ranch, which is presently being utilized by off-road motorcycles, and the Renz acquisition, which is designated for ORV use beginning January 1992.

Calloway and others (1978) state that the record of ownership in Hollister Hills began in 1839, when Governor Alvaredo granted the $218 \mathrm{~km}^{2}(54,000$ acre) Rancho San Justo to Francisco Pacheco. In 1843 Rancho Cienega Del Gabilan was granted to Antonia Chavez, also by Governor Alvaredo. The last owner of the Ranch was Howard Harris, whose greatgrandfather ranched and farmed the property. 


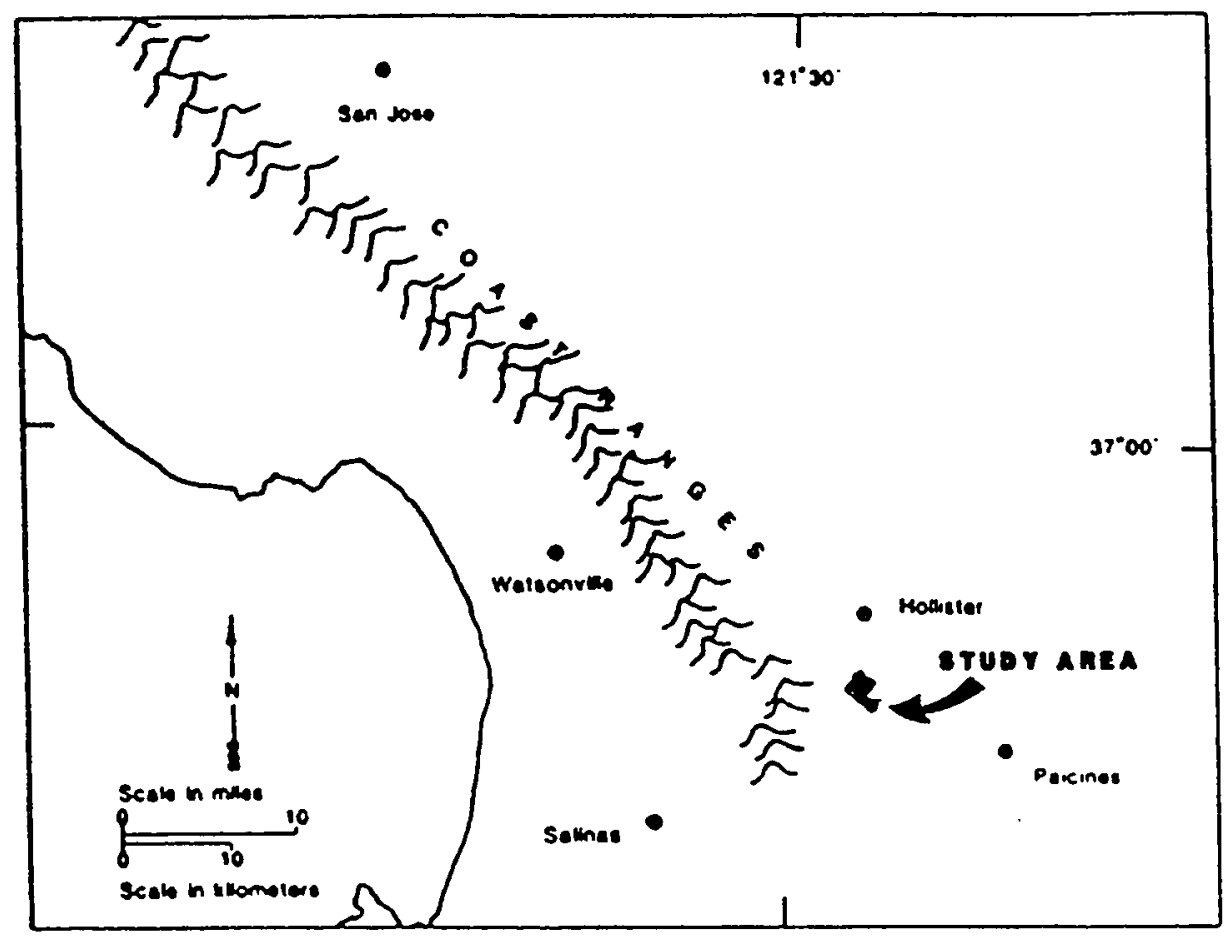

Figure 1. Map of central California showing location of study area. 
The "Bird Creek Hunting Club" introduced ORVs to the area in 1947. Mr Harris opened his ranch to motorcycling groups in 1956, and the first major motorcycle event was held in 1958. In 1970 the Hollister Hills Motorcycle Playground was opened to the general public. The Playground was purchased by the state in 1975, and in october of that year it became an operative unit of the state Park system. It has been used as an ORV facility since that date.

\section{Climate}

The Mediterranean climate of the study area, characteristic of the eastern Coast Ranges of Central California, produces cool wet winters and hot dry summers. Between May and October, temperatures may reach $80^{\circ}\left(26^{\circ} \mathrm{C}\right)$ to $100^{\circ} \mathrm{F}\left(37^{\circ} \mathrm{C}\right)$. Temperatures may fall below $5^{\circ} \mathrm{F}\left(10^{\circ} \mathrm{C}\right)$ for short periods in the winter. Annual precipitation varies from $32.5 \mathrm{~cm}$ (13 inches) in the lower elevations to $58.42 \mathrm{~cm}$ (23 inches) in higher elevations during the months of December to March (Calloway and others, 1978). During normal rainfall years, most of the precipitation comes in the form of large infrequent storms that can trigger mass movement and fluvial erosion. However, drought conditions persisted during 19871990; rainfall totals between Oct 1, 1989 and March 31, 1990 were only $22.35 \mathrm{~cm}$ (8.8 inches) (Harden, 1990). 
Elevations in the study area, which were determined from the 7.5 minute, $6.25 \mathrm{~m} \mathrm{(20} \mathrm{foot)} \mathrm{contour} \mathrm{interval,} \mathrm{1:24,000}$ scale U.S.G.S. topographic map, range from a maximum of 448 m (1400 feet) to a minimum of $165 \mathrm{~m}$ (550 feet).

\section{Surface Hydrology and Vegetation}

The study area includes six ephemeral north-flowing streams. These drainages include five west-facing slopes and six east-facing slopes (Plate 1). The streams flow northeast to the San Benito River through V-shaped valleys.

Riparian vegetation in the study area includes; sycamore, alder, and maple trees. The higher elevations are populated by live oaks, California buckeye and annual grasses, which are dormant during the summer months. Coyote bush and sage are most plentiful on the dry southwesterly slopes, and poison oak is ubiquitous. 
PURPOSE OF STUDY

Funding for the study was made possible by a grant to Dr. Harden from the California Department of Parks and Recreation. This study is a part of ongoing studies of erosion and sediment transport conducted by Harden (Harden and Taylor, 1990).

The purpose of this study was to compare the distribution of mass movement and fluvial erosional features in the Renz Ranch acquisition with similar features in the adjacent, active portion of HHSVRA. Comparison of the two areas provides one means of assessing the impact of off-road motorcycle traffic on erosion rates and processes. In addition, the results of the study will aid trail design in the Renz acquisition. Appropriate trail placement should minimize landslide activity caused by vehicle activity.

The study included: 1) preparation of erosional landform and slope maps; 2) evaluation of causative physical parameters on landslide formation; and 3) an evaluation of the physical factors and ORV activity at HHSVRA, that may influence landslide and fluvial erosion processes. 
PREVIOUS STUDIES

Concerns about off-road vehicle (ORV) use primarily involve the effect on the physical and chemical properties of soils. Previous studies suggest that off-road vehicles (ORVs) change these soil properties, thus accelerating fluvial erosion primarily because of the removal of fertile, vegetation-supporting soil. The severity and rate of erosion appear to be governed by several factors, including: the soil type underlying trails used by the ORVs; the type of ORV utilized; and precipitation rates (Calloway and others, 1978). However, no studies have been implemented specifically to document effects of ORVs on large, preexisting erosional landforms.

Webb and others (1978) studied the effects of ORVs on the physical and chemical properties of paired on- and off-trail samples of six soil series of the Diablo-San Benito Association at HHSVRA. They discovered that accelerated fluvial erosion of soil modified by motorcycle traffic was particularly severe in the coarse-grained soils of the Cieneba series on steep slopes. Soil modifications by vehicles included increased surface strength and bulk density and decreased soil moisture in gravelly sandy loam, coarse sandy loam, and clay. Clay loam showed a $100 \%$ increased surface strength, with variably increased bulk 
density, and no decrease in soil moisture. Diurnal temperature fluctuations increased, and organic material and soil nutrients decreased. These property changes increased the erosion potential of the soil, impeded germination of seedlings, and slowed natural revegetation (Webb and others, 1978).

The General Development Plan for HHSVRA (Calloway and others, 1978) concluded that although ORV traffic posed an erosion hazard, a potentially substantial adverse change in landslide and mudflow activity was not likely, or could be mitigated by trail design. Increased slumping and creep activity were considered to be insignificant, because development was not expected to interact with these environmental factors.

Harden and williams (1989) tested the erosional impact of two motorcycles (200 cc and $600 \mathrm{cc}$ ), piloted by the same rider, on a single east-facing $14.8^{\circ}$ slope underlain by san Benito clay loam. Two parallel tracks were outlined on the slope. After 16 runs, results indicated that eroded material was maximized on the lower, most gentle portion of the hillslope, because of the initial acceleration required to climb the hill. The smaller bike produced $207 \mathrm{~kg}$ (460 lbs) of eroded material while the larger bike produced 194 
$\mathrm{kg}$ (432 Ibs) of eroded material.

Wilshire (1977) and Wilshire and others (1978) investigated the effects of ORVs at seven Bay Area ORV sites and nine other arid and semi-arid sites in California. Results indicated that, in addition to destroying the natural surface stabilizers, the vehicles erode the uppermost fertile portions of the soil mantle.

Snyder and others (1976) used two widely separated sites in California to evaluate the impact of ORVs on the landscape and hydrogeology. Each of the sites was divided into used and unused portions. Compaction of soils and reduction of permeability appeared to be the most serious hydrologic impact of motorcycle use at Panoche Hills in central California. The area used by motorcycles produced about eight times as much runoff from the well-drained sandy loams, as did the unused area. Similarly, sediment yield from the used area was $857 \mathrm{~m}^{3} / \mathrm{km}^{2}$ while the quantity of eroded sediment from the unused area was too small to be measured by standard survey methods.

At Dove Spring Canyon in southern California, erosion surveys showed that degradation of trails mantled by a weathered granite soil, was as much as $0.3 \mathrm{~m}$ between 1973 
and 1975 .

The effects of ORVs on plant and animal life at Hollister Hills in high- and low-use areas were evaluated by Jones (1988). A lower diversity of plant life species and fewer fish and mammals were observed in high-use ORV areas. The predominance of oak in high-use areas was attributed to dust, trampling, and modifications of plant litter cover by vehicles, which subsequently prevented germination of other seedlings. Additionally, the ability of the natural litter cover to retain water can be critical for the survival of many species of wildlife. The differences in the amount and distribution of the litter cover could be one of the factors that has led to the reduced species diversity in the high use sites for many wildlife groups including plants (Jones, 1988) . 
TOPOGRAPHY

\section{Slope Map}

In order to determine the range of slopes on which landsliding is most common, a slope map (Plate 2) of the study area was constructed from a 1:6000 scale base map.

The study area was outlined and transects of various lengths were constructed perpendicular to the contour lines. Slopepercent was calculated by dividing the vertical change in elevation (rise) by the length of the transect (run). The number was then multiplied by 100. The result was assigned to one of five designated slope steepness categories. The area underlain by that slope percent was then outlined.

slopes range from gentle $(0-10 \%)$ on ridge crests and in alluvial channels to very steep ( $>100 \%)$, generally at the higher elevations in the transverse stream valleys (Plate 2). Most are moderately steep (11-30\%). Slopes on the Lower Ranch range from gentle to very steep, but most are moderate. Generally the slopes in the adjacent Renz acquisition are steep. However, very steep slopes in the Renz are rare (Plate 2 ). 
Table 1. Percentage of study area underlain by slopes of various steepnesses.

\begin{tabular}{llll}
\hline $\begin{array}{l}\text { Category } \\
\text { Percent }\end{array}$ & $\begin{array}{l}\text { Slope } \\
\text { Category }\end{array}$ & $\begin{array}{l}\text { Area in } \\
\text { (acres) }\end{array}$ & $\begin{array}{l}\text { Percent of } \\
\text { total area }\end{array}$ \\
1 & $0-10$ & 197 & 8 \\
2 & $11-30$ & 1395 & 63 \\
3 & $31-60$ & 456 & 20 \\
4 & $61-100$ & 157 & 8 \\
5 & $>100$ & 8 & 1 \\
\hline
\end{tabular}




\section{GEOLOGY}

An understanding of the bedrock geology of the area is imperative in any landslide study. A previously compiled geologic map of the study area (Rogers, unpublished), as well as field mapping were used to determine the effects of lithology and structural attitudes on slope instability (fig.4). Formation names in the study area were retained from existing geologic maps of the area (Dibblee, 1980, 1:187,000 scale; Taliaferro, 1945, 1:12,000 scale; and Rogers, unpublished, 1:6,000 scale and 1980, 1:125,000 scale) .

Faults and contacts were mapped from vegetation tonal differences and variations in the erosional character of the units. These are indicated by differences in slope steepness observed on air photos and lithologic changes observed in the field. The geologic map was constructed on a 1:6000 scale topographic base map.

Strike-slip motion along the San Andreas fault during Cenozoic time, has juxtaposed the granitic terrane of the Gabilan Range, against the sedimentary rocks of the eastern Diablo Range (Hill and Dibblee, 1953). At HHSVRA the San Andreas fault separates granitic bedrock west of the study area and sandstone and mudstone underlying the study area 
east of the San Andreas fault zone. On 1:40,000 color infrared air photos (fig. 2) the contact appears as two linear valleys, which separate the densely vegetated terrain at the base of the photograph, from more sparsely vegetated terrain in the upper portion of the photograph (fig. 2).

Detailed aerial photographs and field studies indicate a contact approximately one mile north of, and parallel, to the main San Andreas fault trace (fig. 2). The contact separates a more resistant unit, which contains more sandstone and is vegetated by chaparral scrub, on the south, from a more erodible, slump-prone, unit on the north. The unit to the north appears lighter in color on photos, and generally has a lower overall relief and more subdued topography. It is vegetated primarily by grasses and contrasts with steeper slopes adjacent to the San Andreas fault. Rogers (unpublished) mapped this contact as the Nutting fault, separating the Etchegoin Formation and his unnamed Tertiary bedrock unit to the north. The general features of the rocks at HHSVRA are described below. 


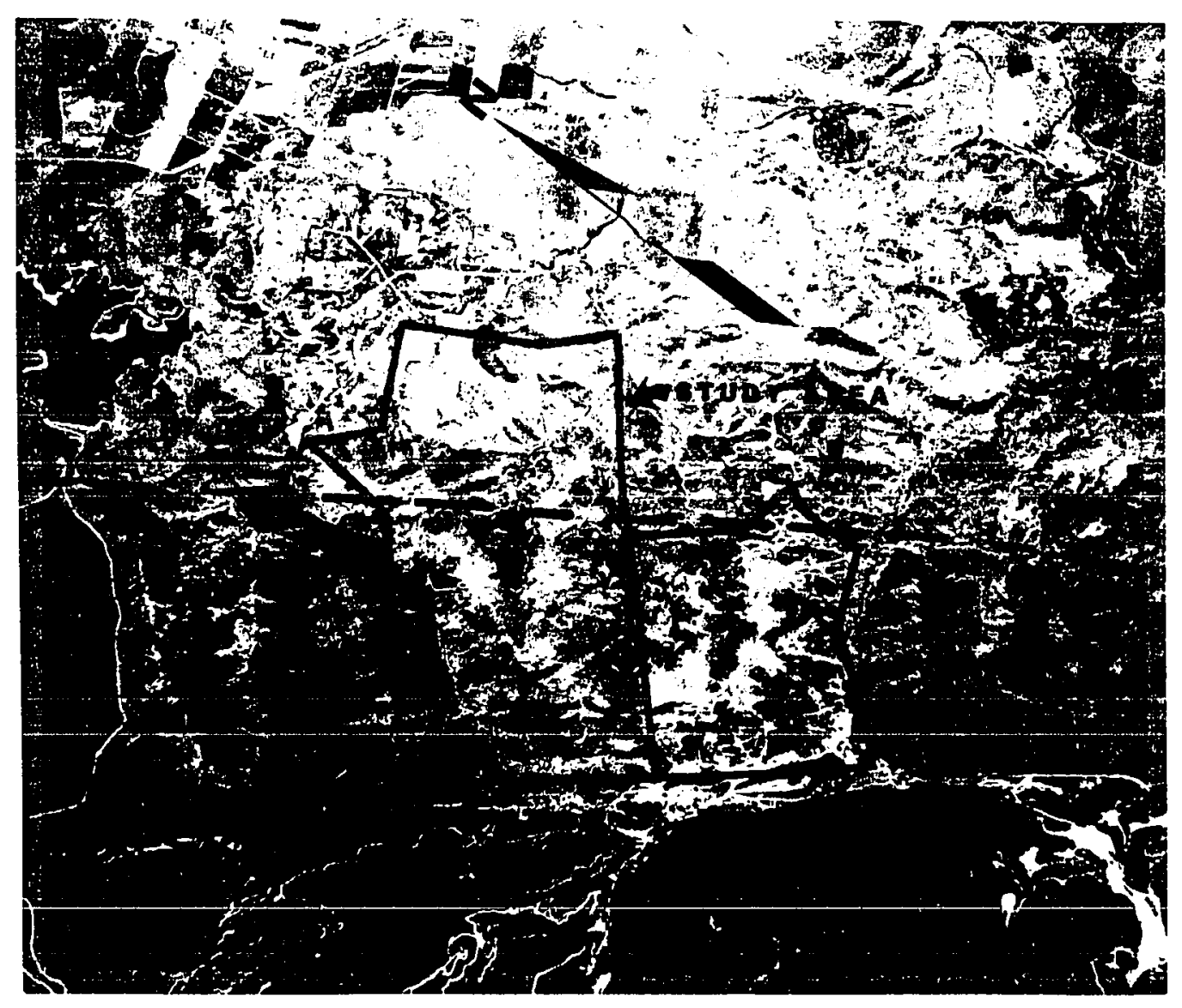

Figure 2. The Iinear valleys at the base of this 1:57,000 scale aerial photograph mark the position of the San Andreas Fault Zone. The dashed line in the middle of the photograph marks the approximate position of the Nutting fault. The solid lines delineate the study area. 


\section{Granitic Terrane}

Basement rocks of the Gabilan range, exposed west of the study area, are part of a broad granitic complex enclosing numerous large metamorphic roof pendants (Compton, 1968). The metamorphic rocks are marble, quartzite, schist, and calc-silicate rocks, many originally dolomitic and graphitic. Their structure and age correlate with the sur

Series of the Santa Lucia range. Exposed plutonic rocks are predominantly silicic, ranging from biotite granodiorite to adamellite and granite. Basic rocks also intruded the quartz diorites (Compton, 1968).

\section{Sedimentary Terrane}

Sedimentary bedrock underlying the study area has been mapped as belonging to either the Etchegoin Formation (Anderson, 1905; Dibblee, 1980; Perkins, 1987), or as Purisima Formation (Jenkins, 1943; Rogers, 1980; Rogers, 1980; Taliaferro, 1945). The Purisima and the Etchegoin are of Pliocene age. They are differentiated on the basis of geographic occurrence and depositional environment. The Purisima crops out in the northern Santa Cruz Mountains and consists predominantly of very thick-bedded yellowish-gray tuffaceous and diatomaceous siltstone, thick-bedded and thickly crossbedded bluish-gray semifriable andesitic sandstone, and thin beds of medium-grained siliceous 
mudstone. Generally, the Purisima Formation records a dominant shoaling-upward cycle, punctuated by several transgressive events (Smith, 1916).

The Etchegoin Formation includes marine and nonmarine sandstone, siltstone, and conglomerate, sandwiched between the San Andreas fault and the eastern Diablo Range, from Hollister south to Coalinga and in the southern San Joaquin Valley, south to Bakersfield (Perkins, 1987). The dominant lithology of surface exposures of the brown sandstone facies of the Etchegoin Formation in the San Benito region, as mapped by Perkins (1987), is a medium- to fine-grained sandstone interbedded with siltstone, and less commonly with conglomerate. Outcrops of sandstone typically are silty, semifriable, and unfossiliferous.

For this study, bedrock in the study area is mapped as part of the lower Plio-Pleistocene Etchegoin formation. The geographic location and lithologic similarities of bedrock underlying the portion of the study area between the san Andreas fault and a parallel fault to the north, the Nutting fault (figs. 2 and 4 ) are consistent with earlier works by Dibblee (1980) and Perkins (1987). Bedrock north of the Nutting fault is mapped as Pliocene unnamed. 
The Etchegoin Formation had been divided into an upper and a lower part by Anderson (1905). The division is based on the occurrence of a bluish-gray sandstone facies, that stratigraphically overlies the older brown sandstone facies. However the formational subdivision was discontinued by Adegoke (1969) and Dibblee (1973) because no regional physical or paleontological characteristics are unique to either of these units.

Sarna-Wojcicki and others (1975) included the study area within a San Andreas fault segment extending from chittenden south to the Cienega Winery, just southeast of Hollister Hills. This segment is generally straight and narrow and includes fault scarps, vegetation lineations, sags, shutter ridges and trenches. The pronounced right lateral offset of Bird Creek in the study area aids in defining the position of the fault zone.

The attitude of the San Andreas Fault Zone is nearly vertical, as shown by the relatively straight outcrop pattern across topography of appreciable relief. However, at one location, $5.6 \mathrm{~km}$ ( 3.5 miles) northeast of the Almaden Cienega Winery, the fault dips to the southwest (Rogers, unpublished). Geophysical evidence of a 70-degree southwest dip along the Santa cruz segment to the north was provided 
when the locations of aftershocks of the of the 1989 Loma Prieta earthquake were plotted an a vertical, NE-SW cross section (Plafker and Galloway, 1989).

\section{Structure}

The San Andreas fault zone marks the boundary between the Pacific and the North American plates and is the most prominent geologic feature in the Hollister 1:24,000 scale quadrangle (fig. 2). The San Andreas fault zone extends from the Gulf of California in northern Mexico northwestward to Cape Mendocino in northwestern California, a distance of more than $960 \mathrm{~km}(600 \mathrm{mi})$. Movement within the fault zone has been distributed along many nearly parallel faults that differ in age and in displacement.

\section{Seismicity}

The study area is located in an area of high historic seismicity (fig. 3). The history of remote and local earthquakes felt in the study area was gathered from the following respective sources: Nason (1971); Harvey and Associates (1989) and Rogers (unpublished).

Nason (1971) subdivided the San Andreas fault into three sections, with the central portion lying between watsonville and Cholame, and including the study area. Nason (1971) 
concluded from 1934 to 1968 seismic data that the creep characteristic of the central portion is the result of the presence of weak "gouge" and stresss in the fault zone. Measurements of creep at the Almaden-Cienega Winery, just south of the study area, showed a marked change in slippage rates before and after a moderate (Mag. 5.6) local earthquake in 1961 (Nason, 1971). Abnormally high (4 cm/yr) slippage rates were recorded several years before the 1961 quake. This rate represented an increase of approximately $1.7 \mathrm{~cm} / \mathrm{yr}$. Following the 1961, fault creep rates dropped to near zero for nearly 18 months. Rates returned to the average of $1.2 \mathrm{~cm} / \mathrm{yr}$ over a period of 5 years. Data preceding the Mag. $\geq 7.1$ Loma Prieta Earthquake of October 1989 indicated that creep rates averaged $5 \mathrm{~cm} / \mathrm{yr}$ (Calloway, 1978). Current rates are measured at the San Andreas Geological Observatory, located along Bird Creek in the granitic section of the Lower Ranch and operated by the University of California. Additional faults in the area include the Morse fault, the Harris Ranch fault, the cienega Road fault and the Nutting fault (fig. 4; Rogers, unpublished). 


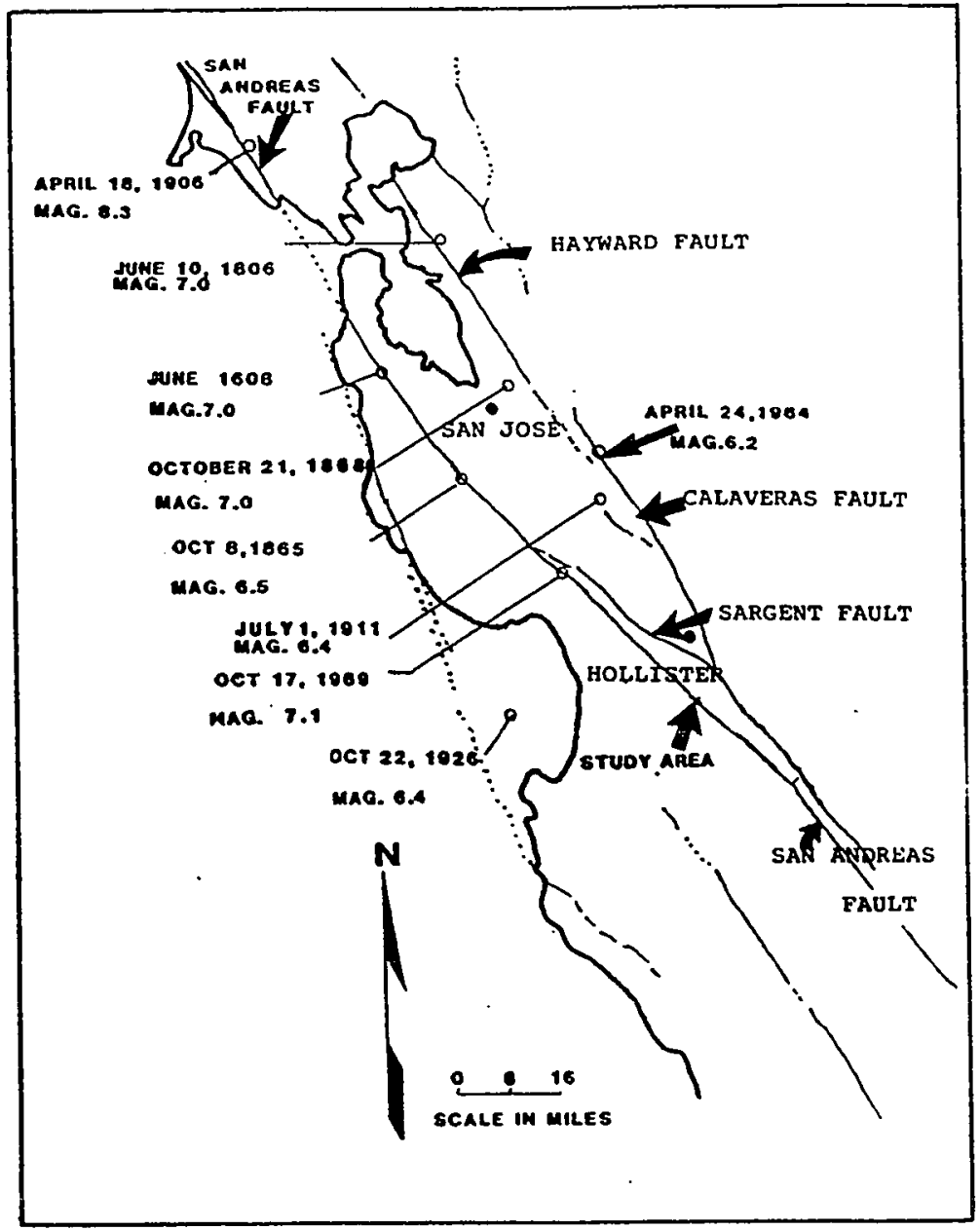

Figure 3. Historic San Francisco Bay Area earthquakes greater than magnitude 6.0 associated with the San Andreas Fault Zone. (Modified from Harvey and Associates, 1989) 


\section{EXPLANATION}

Pliocene Sedimentary Rocks

Unnamed Unit

Interbedded green and tan, poorly consolidated, fine-grained sandstone and claystone.

Te Etchegoin Formation of T.W. Dibblee

Interbedded, tan, medium- and fine-grained sandstone interbedded with micaceous sandy and clayey siltstone. thinly bedded, generally unfossiliferous and crossbedded, abundant purple concretions, ash bed present.

Map Symbols

I Fault, dashed where uncertain

$7_{40}$ Strike and dip of bedrock

$\gamma_{49}$ Strike and dip of overturned bedrock

L Boundary between Renz Aqusition and Eastern HHSVRA

$\cdots$ Trails

Streams

- Location of ash sample

$\nabla$ Location of leaf fossil

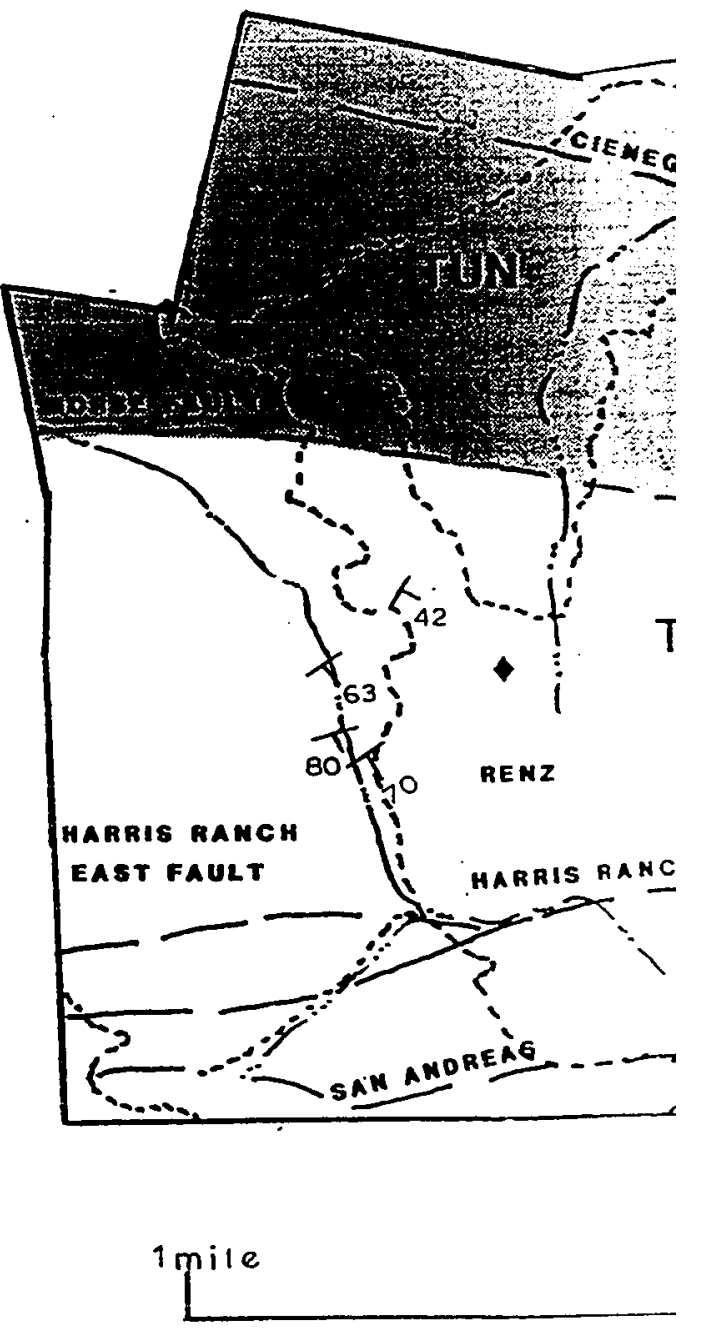

Figure 4. Generalized Geologic map of the study area from Rogers (unpublished) and field mapping (this study). 


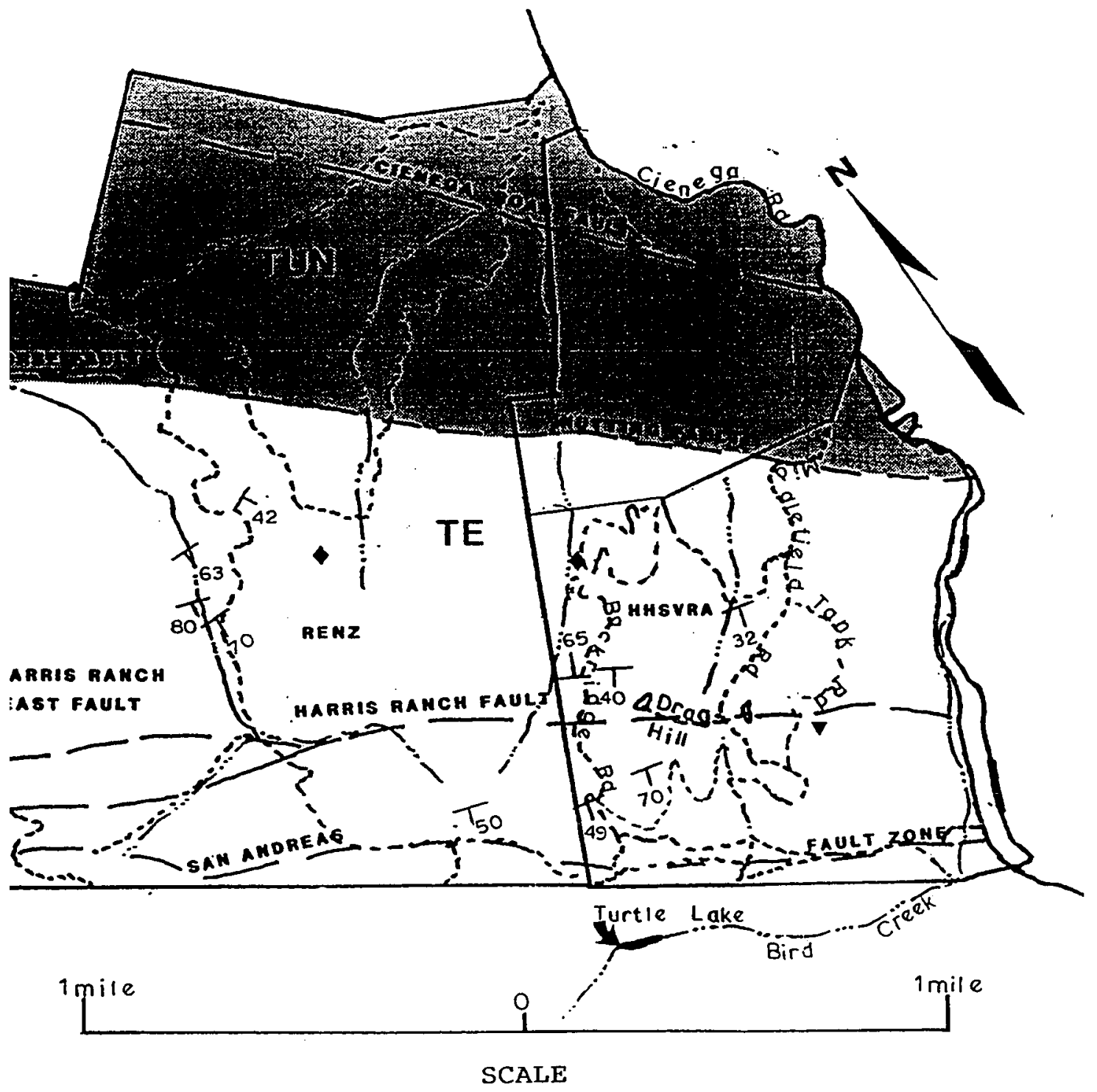

- of the study area sping (this study). 



\section{Results of Field Mapping}

Geologic investigations in the field consisted of a detailed survey of the entire study area. The slopes were investigated chiefly for lithologic types, bedding attitudes, cementation, weathering, and planes of weakness. Bedrock attitudes were measured at roadcuts and places where the bedrock had been stripped of soil by ORV traffic (fig. 5).

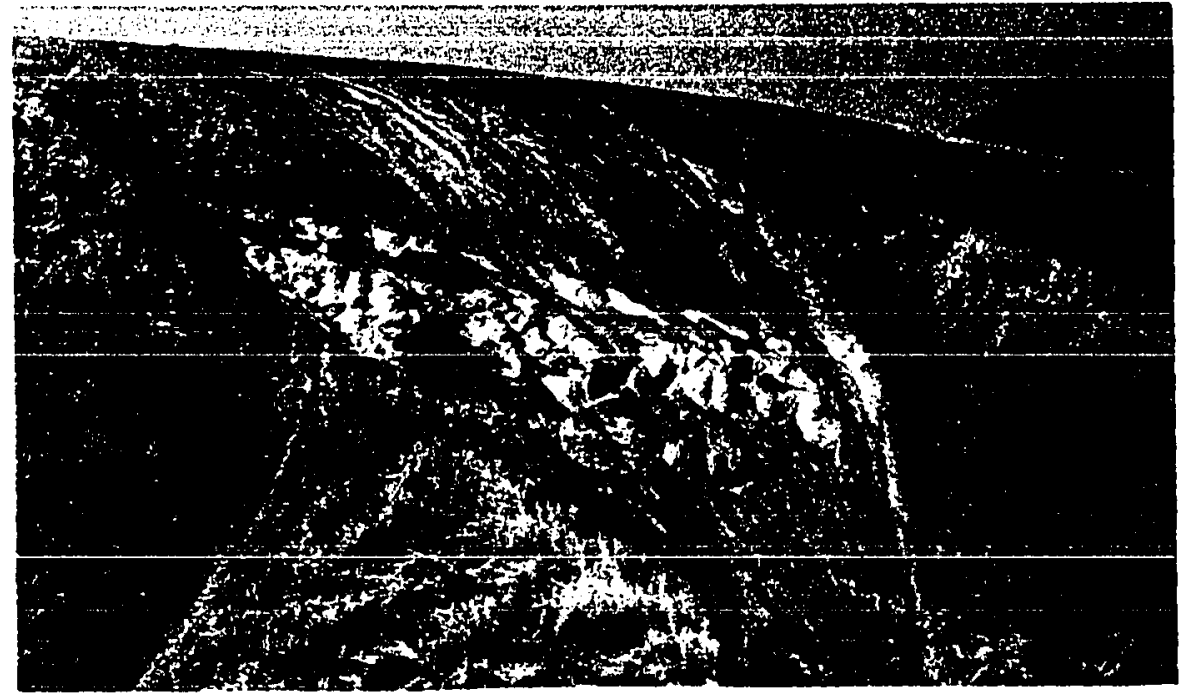

Figure 5. Outcrop of Etchegoin Formation sandstone on a west-facing slope of Drag Hill where soil has been stripped to expose bedrock. 
Rocks closest to the San Andreas Fault zone in the study area were mapped as part of the Etchegoin formation because of lithologic similarities to rocks described by Perkins (1987) in a measured section in wharton Canyon. Rocks north of the Nutting fault (fig. 2,4) were mapped as part of an unnamed Tertiary unit. Locally, the strike of the bedrock is coincident with the direction of the fault zone, approximately N40W. In general, dips range from $20 \mathrm{sw}$ to 46SW. However, several northward dips of similar magnitude were observed. Rogers (unpublished) provides a schematic cross-section of an area just east of Bird Creek (fig. 6).

Some sandstone beds seem to be overturned because the sharp erosional contacts and coarse grains that normally mark the base of these beds presently overlie the fine-grained top of the beds (fig. 7). Additional evidence of overturned bedrock in the study area was provided by well logs (Mr. Cullum, Cullum Well Drilling, oral communication 1989) of the rock formations at Bird Creek and other locations south of the Nutting fault in the study area. The logs indicate a blue sandstone and gravel member underlying a brown sandstone member. The blue sandstone was encountered from 8.1 to $25 \mathrm{~m}$ (27 to 75 feet) below the surface (Cullum, oral communication). Perkins (1987) mapped the blue member as the younger unit in wharton canyon. 


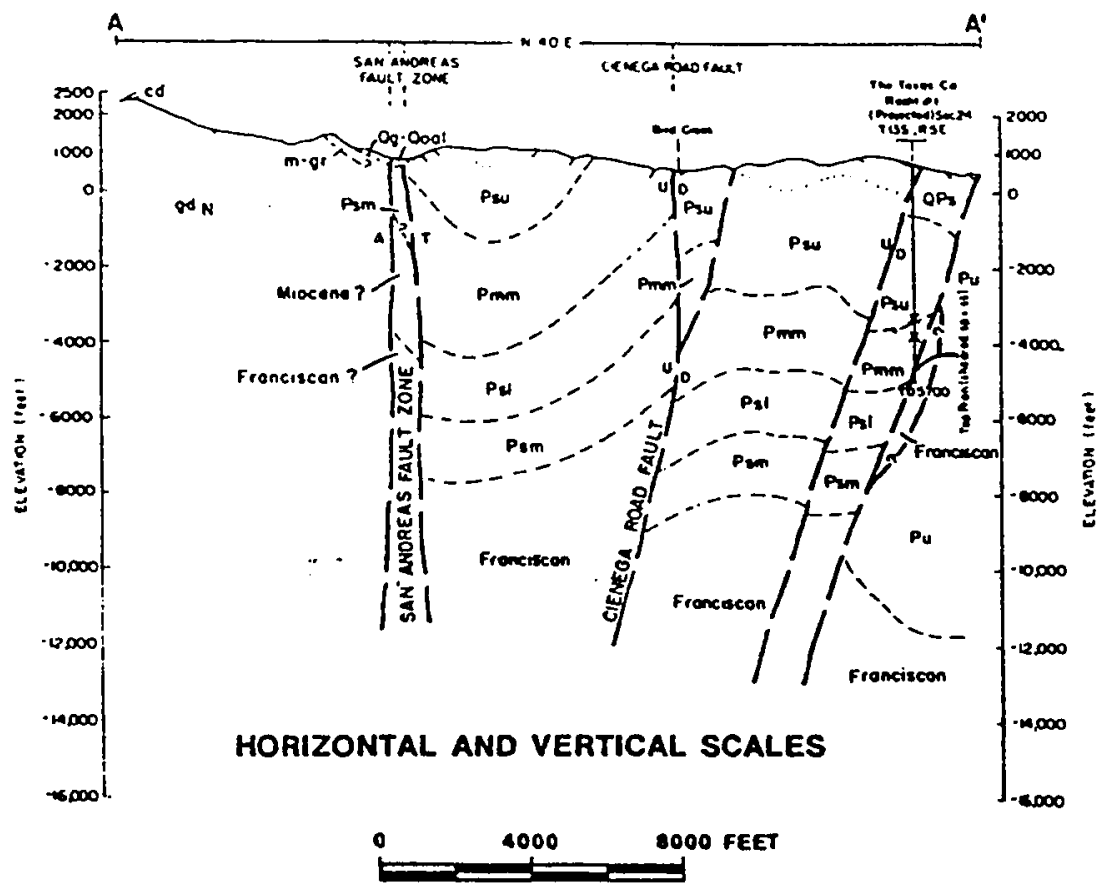

Detum - See Level

\section{EXPLAMATION}

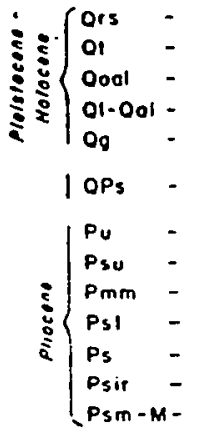

River sond

River terroce deposits

Old alluvium

Undifferentiated fine-grained lacustrine and alluviol deposits

Alluviol gravel and sand

Unconsolidoted sond, sill, and grovel

Undifferenioted "Purisimo Formotion"

"Purlsimo Formotion" - Upper non-morine sondslone member

"Purisimo formalion" - mucky mudstone member

"Purisimo Formotion" - lower non-morine sondstone member

"Purisimo formation" - undifferential non-morine sondstone member

"Purisimo formotion" - red-moroon sondstone member (within Psl member)

Undifferential "Pufisimo Formotion" (morine sondstone member) ond Miocene sediments; presence of Miocene is uncertoin. projected southeosterly from Chillenden quadrangle

Figure 6. Schematic cross section of the San Andreas Fault zone in the study area (Rogers, unpublished) 
The study area, as mapped by Rogers (1980) lies within the western portion of the San Justo Structural Block. The San Justo Structural Block is approximately $6.8 \mathrm{~km}$ (4 miles) long and $1.7 \mathrm{~km}$ ( $1 \mathrm{mile}$ ) wide and has been deformed into a overturned fold adjacent and parallel to the San Andreas fault zone.

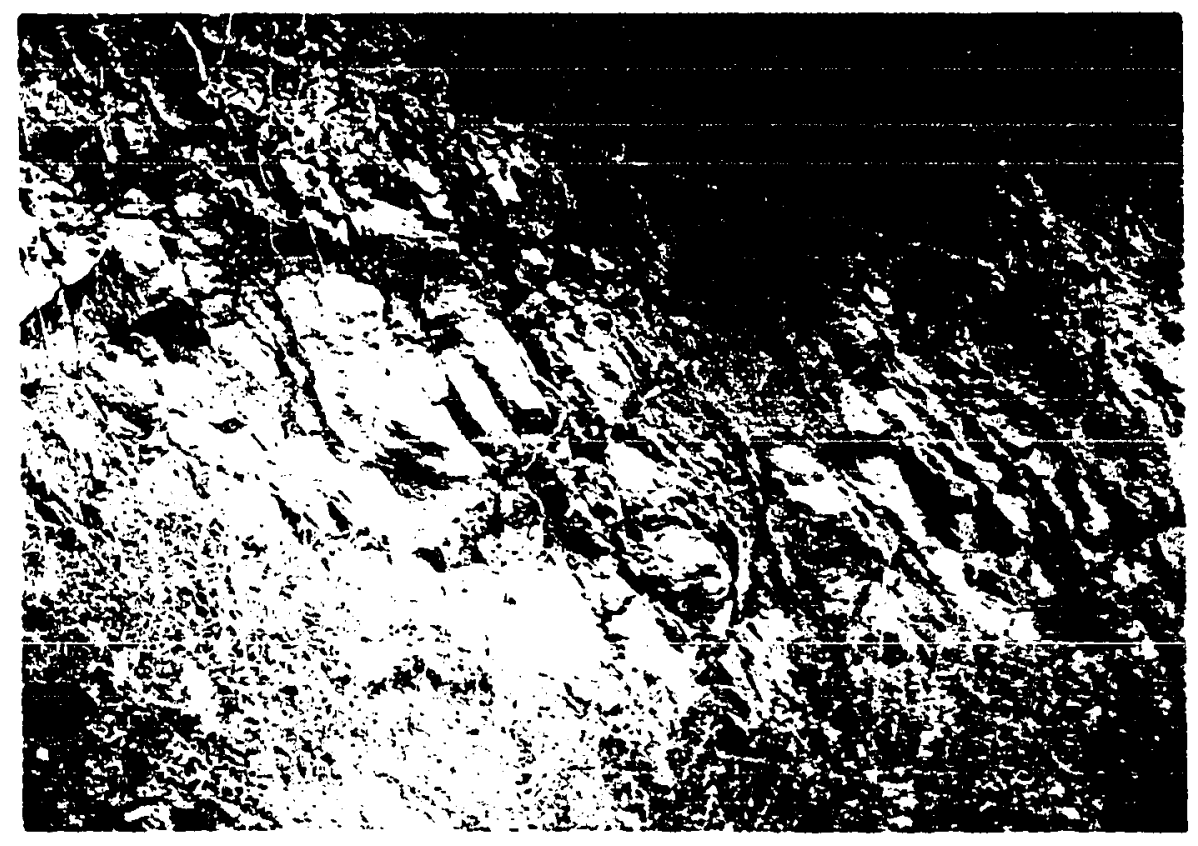

Figure 7. Outcrop of overturned, interbedded mudstone and sandstone displaying concretions in study area. 
Etchegoin Formation

The principal bedrock unit in the area is mapped as the Etchegoin Formation, which consists of micaceous, generally unfossiliferous sandstone and mudstone. This Pliocene unit is highly jointed, and distinguished by abundant concretions, and an interbedded ash bed. The strike of the ash bed is assumed to parallel the strike of the bedrock, because it was found in two locations in the study area in a direction approximately parallel to the strike of the san Andreas fault zone (figs. 2 and 4 ). The fine-grained, buffcolored ash bed displayed no internal structure and a homogeneous texture. Examination of a crushed sample by polarizing light microscope revealed an assemblage of angular opaque and isotropic particles, which were interpreted as glass, and a minor amount of iron oxides particles.

Oval mudstone and sandstone concretions, approximately 12.7 $\mathrm{cm}$ in diameter and ranging in color from purple to graybrown, are most common in the strata closest to the fault zone. Large deposits of carbonized plant remains, some with gypsum crystals, are in the mudstone units. One leaf fossil, which was accidentally destroyed prior to being identified, was discovered in a sandstone bed close to the intersection of Tank road and the Harris Ranch fault (fig. 4). 
Primary sedimentary structures in this unit are found mostly in the $23 \mathrm{~cm}$ thick, semifriable, normally graded sandstone beds.

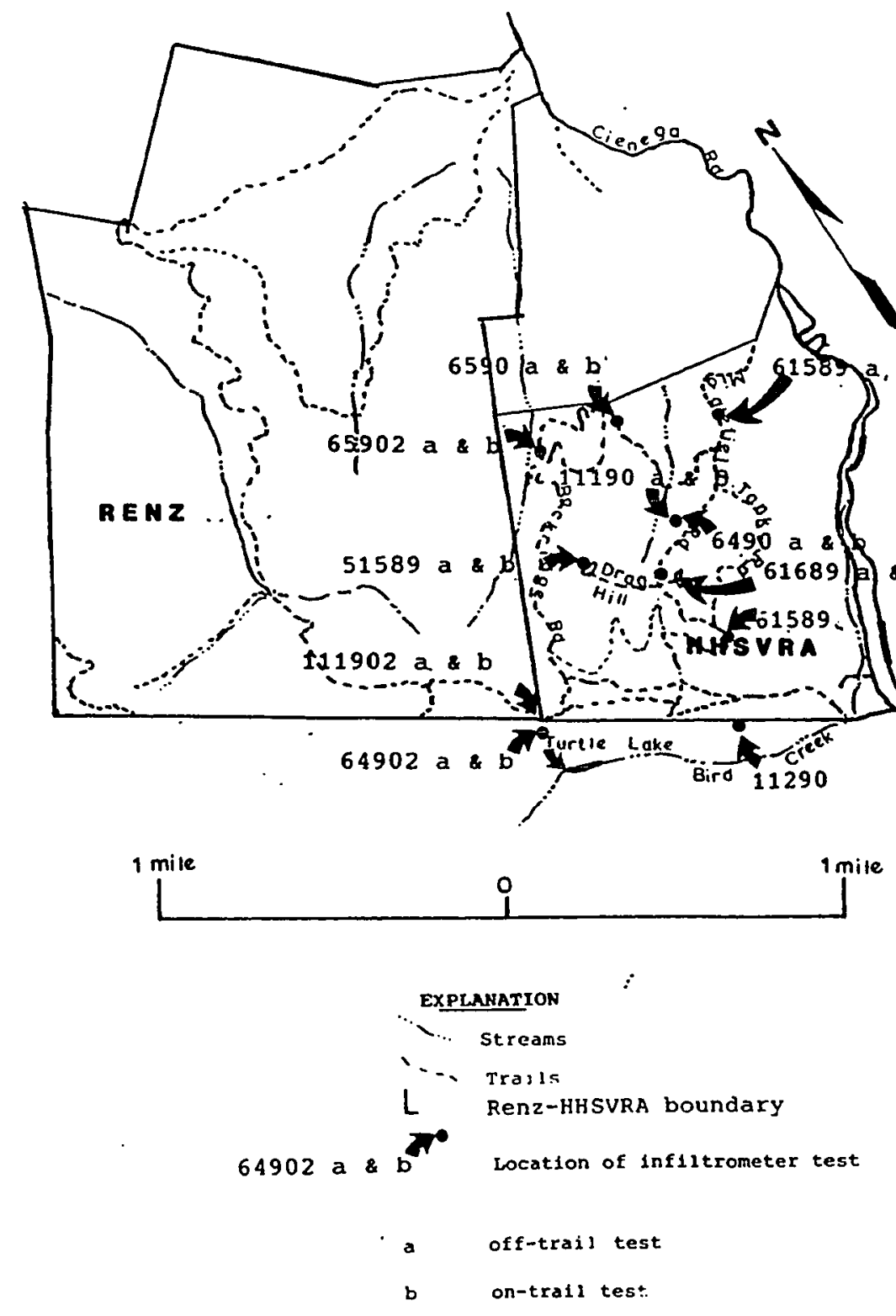

Figure 8. Location map of the study area. 
These stacked sequences formed several outcrops that are exclusively sandstone. Most are cross-bedded and some are channelled. The fissile, laminated mudstone beds are typically thinner than the sandstone beds and range in thickness from $15 \mathrm{~cm}$ to $0.6 \mathrm{~m}$.

The șandstone is semi-indurated, brownish-gray, and weathers to a tan color. Thin sections reveal a well sorted, grainsupported assemblage of sub-angular to sub-rounded particles of plutonic and polycrystalline quartz, feldspar, mica, and volcanic rock fragments cemented by calcite. The presence of plutonic quartz, feldspar and mica suggests an origin from the Salinian block to the west. Volcanic rock fragments indicate that the Franciscan Assemblage may have contributed detritus to the formation.

Rocks throughout the study area are cut by at least two systematic joint sets. The first joint set roughly parallels the trend of the San Andreas Fault Zone and dips to the northeast. The second set strikes northeast and dips northwest. The surfaces of the joint sets are coated with secondary calcite, which suggests the movement of ground water through the cracks. 
Unnamed Formation

Outcrops in the unnamed unit are scarce. Where exposed, the unit consists of unfossiliferous, very poorly lithified, olive-green and tan claystone with some interbedded sandstone. Concretions are much less abundant, smaller, and yellow in color compared to the purple concretions of the Etchegoin. Bedding thicknesses are difficult to ascertain because of the highly bioturbated or poorly stratified nature of the rocks. Some cross bedding was noted. Bedding appeared to be positioned normally because some sandstone cross-beds contained clasts of an underlying claystone unit. Some penecontemporaneous load structures are visible. Carbonized wood, containing gypsum crystals, was found outside the area approximately $0.4 \mathrm{~km}$ north of the Cienega Road fault of Rogers (unpublished). 
SOILS

Information about the soils in the study area was published by the United States Department of Agriculture (1969). At least nine individual soils series mapping units occur northeast of the fault zone in the study area (Harvey and Associates, 1989). These are locally referred to as "Adobe" soils. A soil series is a group of soils having horizons similar in differentiating characteristics and arrangement in the soil profile, except for texture at the surface portion (top 13-20 cm). In order of decreasing abundance the nine soils series include the Diablo (DaE2, DaF2); San Benito (SBE2, SbF2, SbF3); Nacimiento (NcG3); Clear Lake (Ch); and Cometa (CoD2, Cnd2) soil series. Additional, less common soil units in the study area are Badland (Bag), Terrace (TeF) and Sandy alluvial ground. (Sc). These soil series belong primarily to the Diablo-San Benito Association, which is underlain by sandstone and mudstone. Rogers (unpublished) collected soil samples from two undisclosed locations in the unit mapped as the Etchegoin for engineering classification. Both samples contained less than $1 \%$ sand. Silt contents ranged between $78.3 \%$ and $48 \%$ Plasticity indexes were high, $71.1 \%$ and $90.4 \%$ Clay mineralogy was beidellite with trace amounts of mica and chlorite. Distribution of soils and their mode of occurrence are illustrated in figure 9. 

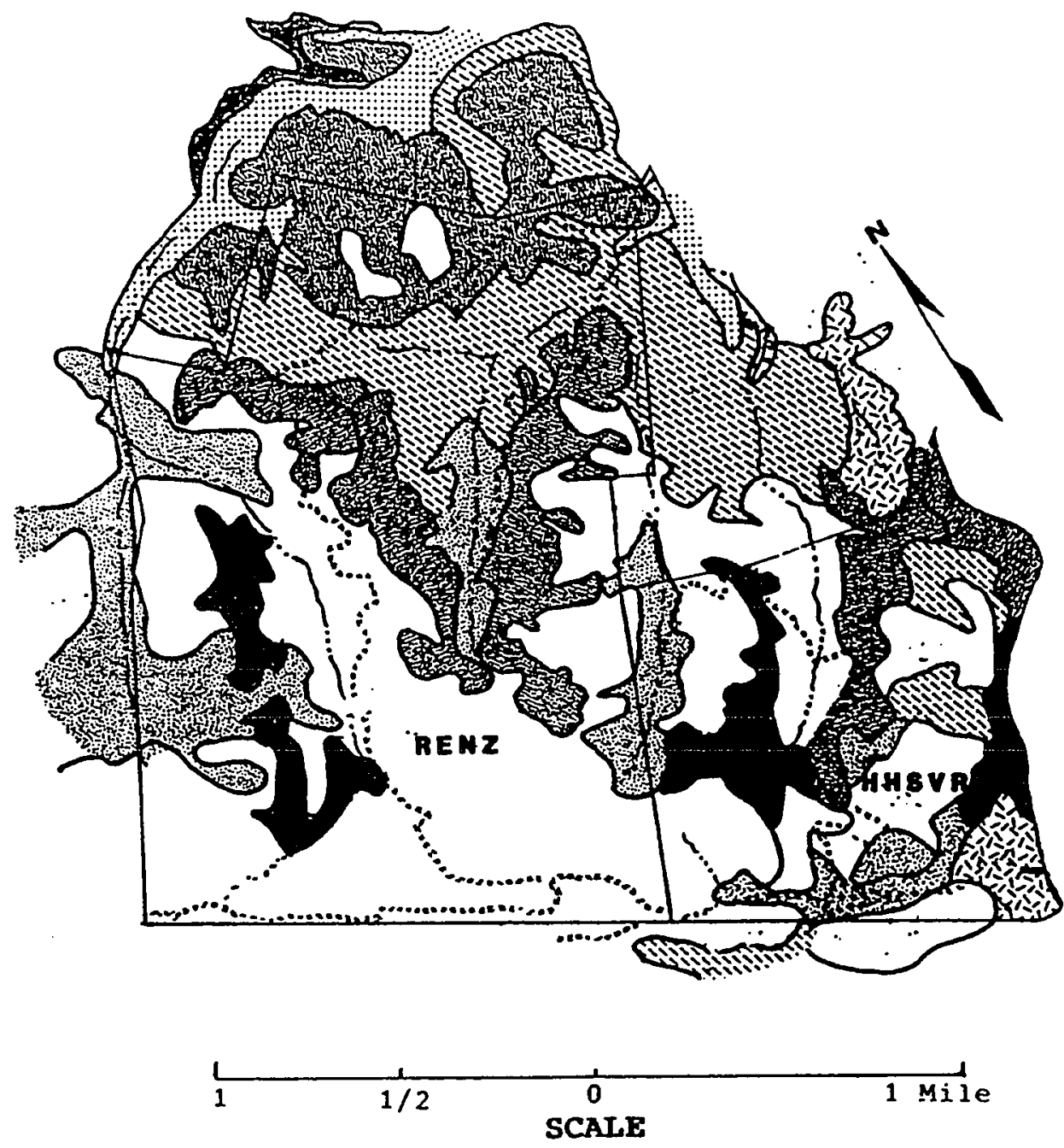

Soil

type Description

ED BaG Badland

[Ch Clear Lake clay

DaE2 Diablo Clay, 15 to $30 \%$ slopes, eroded

ET DaF2 Diablo Clay, 30 to $50 \%$ slopes, exoded

NCG 3 Nacimiento Loam, 30 to $75 \%$ slopes, severely eroded

SbE2 San Benito Clay Loam, 15 to $30 \%$ slopes, eroded

SbF2 San Benito Clay Loam, 30 to 508 slopes, eroded

ET TeF Terrace Escarpments

0 CnD2 Cometa Loam, 5 to $15 \%$ slopes, eroded

Figure 9. Distribution of soils in the study area (modified from Harvey and Associates, 1989). 
Soils mapped in the study area were examined because individual soils provide varying resistance to erosion. Some correlation between the arrangement of the soils and the spatial distribution of landslides in the study area was noted. Soils north of the Nutting fault (fig.4, 9) were mapped almost exclusively as part of the Diablo series. This highly erodible soil series, which contains the highplasticity, low-strength clay, montmorillinite, (U.S. Department of Agriculture, 1969) underlies a portion of the study area characterized by a dispropotionately high density of slump/earth flows. Slopes south of the Nutting fault are not as highly impacted by any landslide type.

Three of the five piping features in the study area occur in soils of the San Benito series. Soils where piping occurred in the study area, are highly desiccated, indicating highly expansive properties. 


\section{EROSIONAL LANDFORMS}

Erosional landforms in the study area were mapped during 1989, and activity levels of landslides and gullies in the Renz were compared to activity levels in the eastern portion HHSVRA. Field reconnaissance, aerial photos flown in 1947 , 1973,1979 , and 1988 at scales ranging from 1:6,000 to 1:80,000, and personal communication with landowners Al Renz and Howard Harris were used in compiling the map erosional landform map (Plate 1). The large-scale photographs were used for detailed mapping of the larger landslides. Mapping was done on a 1:6000 scale topographic base, map and resulted in the identification of 48 slump/earthflows, 40 debris slides and avalanches, 14 slumps, 2 rock falls, 4 piping features and 6 gullies (Plate 1). An electronic planimeter was used to measure the area of each landslide from the 1:6000 scale topographic base map. The percent of the area covered by landslides was determined by dividing the sum total of the area covered by landslides by the total area in the Renz acquisition and the active part of HHSVRA. The result was then multiplied by 100 to obtain the area. The combined area of the erosional features mentioned above cover 22 percent of the study area.

Active landsliding in the study area is indicated by the disturbance of short-lived vegetation, man-made features 
such as roads and fences, and by the appearance of slides on more recent aerial photographs. Many of the larger features in the study area exhibit scars from several mass movement and fluvial processes. These features would be more appropriately named landslide complexes. However, for the sake of clarity, landslide complexes were classified into more specific categories by features indicating their dominant mode of mobilization.

Landslides mapped in the study area are classified according to Table 2.1 in Telfer (1988), which was modified from Schuster and Krizek (1978). Schuster and Krizek (1978) defined a landslide as a group of slope movements wherein shear failure occurs along a specific surface or combination of surfaces. Although disagreement exists in the literature concerning the nomenclature of various types of landslides, it is generally agreed that the principal factor that differentiates types of landslides is the amount of water involved. Falls, slides, and slumps are failures that generally involve considerably less moisture than flows (Varnes 1978, Plate 1).

Because landslide mobilization in the study area was not observed, classification is based on the landforms that are the results of the processes mentioned above. Falls and 
slides generally were observed to have a higher degree of internal disorder than slumps, and they sometimes consisted of semi-independent units. Slumps are a more cohesive mode of failure and therefore produce larger semi-independent units. Flows generally involve more water (Varnes, 1978). The displaced mass of flows appears more hummocky and resembles a viscous fluid.

In a similar study of mass movement by Harden and others (1976), hillslope erosion processes were grouped into two categories on the basis of the relative importance of running water in the process. Mass-movement processes move soil, colluvium, rock, vegetation, and organic debris downslope under the dominant influence of gravity. Times, styles, and rates of mass movement are strongly influenced by soil moisture and ground water, but surface water has less effect. Fluvial processes move soil, colluvium, rock, and organic debris downslope and downchannel under the dominant influence of running water (Harden and others, 1976). The most common hillslope processes and deposits in the study area are described in the following sections. 


\section{Mass Movement}

\section{Slump/Earthflows}

Large slump/earthflows appear as elongate, spoon-shaped features. These features are mostly found in pre-established drainages and most have subtle, well-vegetated features. Their upper zones of depletion are easily identified on large scale-aerial photographs by their concave, amphitheater shape. The toes of these features usually abut the major drainages of the area. Preliminary field reconnaissance indicated the presence of well developed desiccation cracks in the heads of most of the slides that are concave toward the slide and approximately 1 to $7 \mathrm{~cm}$ wide with depths greater than $0.3 \mathrm{~m}$.

Elongate, convex-upward surfaces underlain by colluvium are present at the toes of several of these features and were probably deposited by a combination of downslope slumping, flowing, and translational sliding. Historically, movement in this landslide type elsewhere has progressed at rates approaching $2 \mathrm{~m} / \mathrm{yr}$ (Harden, verbal communication) .

Slump/earthflows in the study area are as small as $.002 \mathrm{~km}^{2}$ (.6 acres). Others are huge coalesced flow complexes as large as $.2 \mathrm{~km}^{2}$ (58 acres). The body of large 
slump/earthflows typically includes depositional plugs of colluvium, and axial gullies. The depositional plugs occur at breaks in slope. Although vegetation and subdued topography indicate that the slump/earthflows have been inactive for at least 10's to 100 's of years, some features are presently active. One such slump/earthflow appears in the northern tip of the Renz study area (Plate 1). Its level of activity was inferred from the presence of undermined wooden fence poles that have since been replaced by metal poles.

An example of a well developed slump/earthflow is the large coalesced unit at the intersection of the San Andreas fault zone and Cienega Road adjacent to Bird Creek (Plate 1). This large dissected bowl shaped failure contains multiple smaller, more recent slides within the main landslide complex. The small slides could cause undercutting of central cores of undisturbed rock and colluvium, gradually enlarging the smaller internal units. Both the presence of previously mentioned disturbed manmade features and the smaller recent landslides inside larger slides indicate that erosion in the study area is ongoing.

Most Slump/Earthflows in the area are characterized by any combination of the following : 
a) average size $.04 \mathrm{~km}^{2}$ but can be as large as $.23 \mathrm{~km}^{2}$.

b) a concave amphitheater shape visible on large scale aerial photos

c) location at the heads of pre-established drainages

d) subdued and vegetated head scarps

e) axial gullies, internal undisturbed rock and colluvium masses and plugs of deposited colluvium

f) tension and desiccation cracks in the soil above the crown

g) unvegetated toes adjacent to stream course

h) typical occurrence on steep slopes $\left(23^{\circ}-40^{\circ}\right)$

\section{Slumps}

Landslides in the study area that feature backward rotation during downslope movement of an intact mass of soil, rock, vegetation, and colluvium are classified as slumps. In the study area, these features are as small as $.0003 \mathrm{~km}^{2}(.09$ acres) and as large as $.01 \mathrm{~km}^{2}$ (2 acres). Slumps in the study area generally have well developed head and lateral scarps and stepped remnant land surfaces that are tilted into the hillslope. These remnant ground surfaces sometimes bear trees or large bushes that also tilt back into the overall slope. Several of the slumps were found at the base of large inactive slump/earthflows and thus appear to represent reactivation of these slides. A particularly large 
example of an active slump within an older slump/earthflow appears along Cienega Road. Slumping in this feature impacted the road during the wet season of 1983 (Hollister Department of Public Works, oral communication, 1990). Historically, slumps elsewhere have moved at velocities ranging from extremely slow to moderately slow (Varnes 1978).

Slumps in the study area may be characterized by any combination of the following:

a) average size equal $.002 \mathrm{~km}^{2}$ (.68 acres)

b) stepped remnant ground surfaces that dip back into the hillslope.

c) unvegetated lateral scarps at the flanks and minor scarps in the body of the slump

d) occurrence on steep slopes ( $27^{\circ}$ to $30^{\circ}$ usually facing a main drainage. 


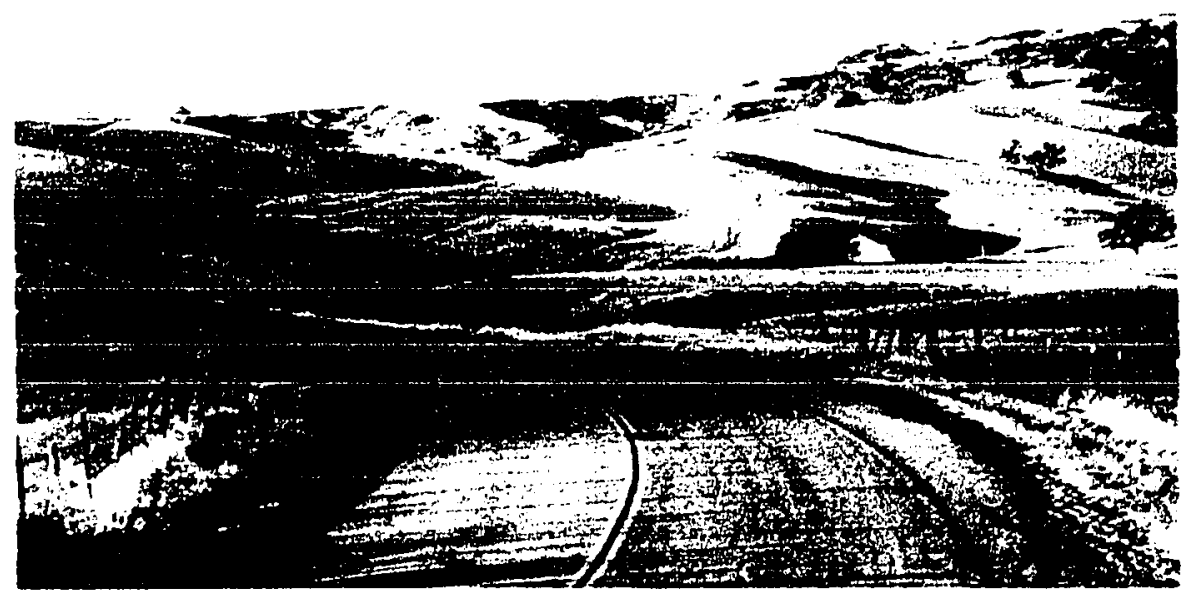

Fig. 10 An active slump within the cienega road slump/earthflow complex. View west toward SVRA.

Debris Slide/Avalanche

Two distinct, active landforms in the study area that have been characterized as debris slides/avalanches warrant particular mention. Both are on the east-facing slope 
adjacent to the western Renz boundary. They are the only debris slides/avalanches that do not appear to have formed in a pre-existing drainage. Both are active, elongate, shallow features, on a steep $\left(38^{\circ}\right)$ slope. However, the avalanche closest to the southern boundary has a distinct main scarp, and is less linear than its counterpart to the north. This debris slide/avalanche is littered with boulders, and colluvium that indicate a high degree of internal deformation. slides of this type traditionally undergo a combination of downslope translation and flowing at very rapid rates that vary from $10^{-4}-30 \mathrm{~m} / \mathrm{sec}\left(10^{-2}\right.$ to $10^{2}$ $\mathrm{ft} / \mathrm{sec}$ ) (Varnes, 1978). Downslope movement in the study area involved soil colluvium and organic debris (fig. 11). 


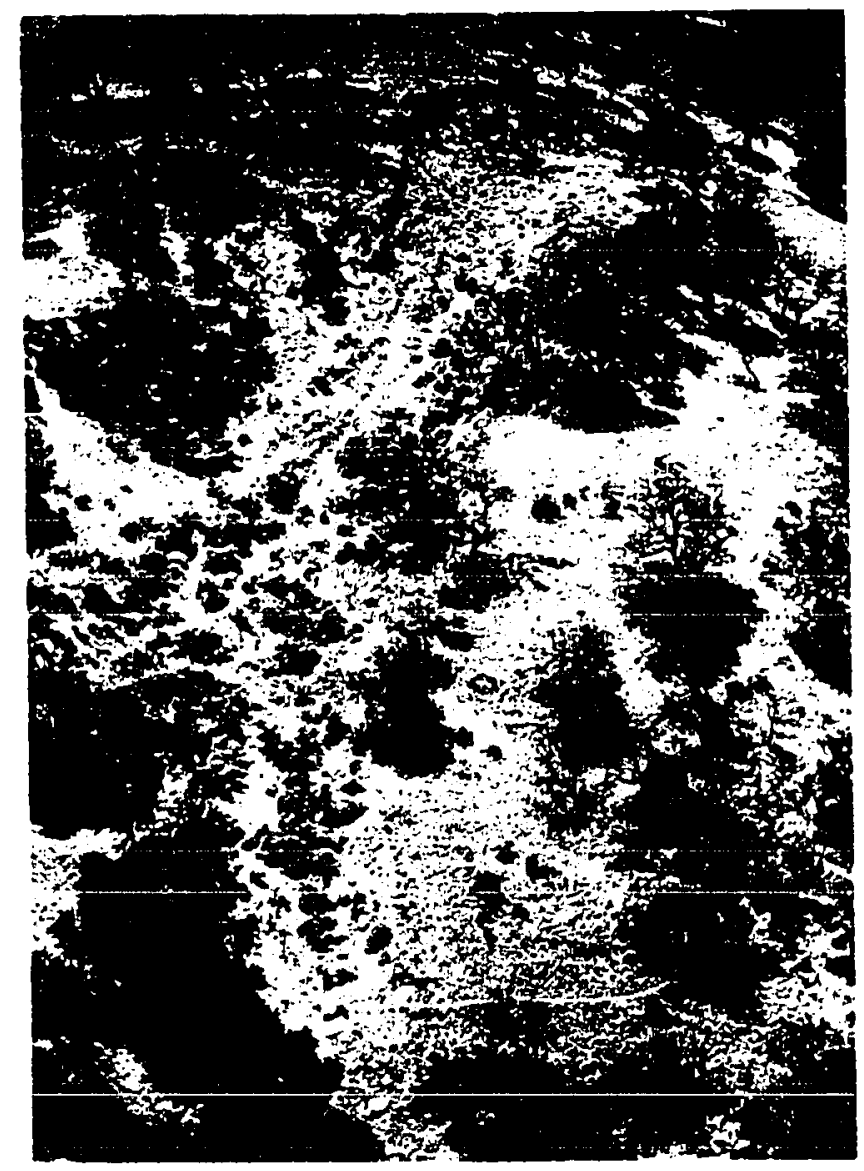

Fig. 11 Debris slide near western boundary of study area. An eyewitness dated the occurrence as during 1986 winter. 
Al Renz, the former owner of the adjacent property, claims that this slide occurred during the unusually wet 85-86 winter. The point where this slide enters the drainage channel at the base of the slope, is highly disrupted by slide debris. The results are a waterfall, and deflection of the stream away from the slide.

Both features are approximately $.002 \mathrm{~km}^{2}(.6$ acres) in area but the northern-most slide, which is beneath the power lines, has no distinct leveed toe or main scarp. Rather, it is a "U"-shaped, more chute-like feature with vertical walls, that appears to have failed by "dry-flowing" as well as avalanching. According to Al Renz, movement on this slide was initiated by wild hogs uprooting the vegetation.

Debris Slides/Avalanches are characterized by any combination of the following:

a) typical size $=.006 \mathrm{~km}^{2}(1.7$ acres $)$

b) high length to width ratio

c) occurrence on steep slopes usually in preexisting drainages.

Small debris slides/avalanches that occur immediately adjacent to channels in the study area were categorized as streamside slides. Streamside slides in the study area are 
characterized by vertical unvegetated banks of soil, rock and colluvium. These are some of the smaller features in the study area, varying in size from $3.3 \mathrm{~m}$ (10 feet) long and $4.5 \mathrm{~m}$ (15 feet) wide to $18 \mathrm{~m}$ (60 feet) long and $30 \mathrm{~m}$ (100 feet) wide. Motion usually involves sliding, avalanching, flowing, and toppling. It is not known whether these features appear in the unexplored drainage channels in HHSRVA, but in the Renz acquisition they are common at the base of the more sparsely vegetated slopes greater than 30 degrees. Some were not mapped when they appeared at the base of much larger mass-movement features, but were included as part of the larger feature. Wherever these slides occur in close conjunction to form a continuous, vertical, unvegetated stream bank, they were mapped as gullies.

\section{Rockfall}

Rockfall is the extremely rapid downslope movement of rocks ranging in size from pebbles to boulders. This results in a deposit of talus at the base of steep slopes. In the study area, this is a relatively rare process occurring in small areas, usually at cut slopes that are underlain competent sandstone. Rockfall sites in the study area are as small as $1.5 \mathrm{~m}$ ( 5 feet) high and $12 \mathrm{~m}$ (40 feet) long or as large as $4.5 \mathrm{~m}$ (15 feet) high and $24 \mathrm{~m}$ (80 feet) in length. An example of one of the larger rockfall sites is on the 
road that follows middle drainage, on the former Renz property. The road was cut on a prominent spur of highly jointed sandstone. Cobble sized rocks litter the road beneath the steep slope, and the slope beneath the road is often covered with fresh debris, indicating that rockfall at this cut slope is an ongoing process that poses a road maintenance problem. Failure occurs when the shear strength of the two systematic joint sets is exceeded by the weight of the rock. The process is facilitated by weathering. Rockfalls have been observed elsewhere at rates aproximating $30.6 \mathrm{~m} / \mathrm{sec}\left(10^{2} \mathrm{ft} / \mathrm{sec}\right)$ rates. Preliminary investigation indicates that this process contributes only minor amounts of debris to the study area.

\section{Fluvial Erosion Processes}

Piping

Subsurface erosion or piping was observed at four locations in the study area (marked by a large $\mathrm{P}$ on Plate 1). This erosional feature is a small subterranean tunnel that sometimes collapses, forming a gully. One example of piping is approximately $150 \mathrm{~m}$ (500 feet) east of Middlefield road between Tank and Beverlys Roads (fig. 8). At the uphill end, the pipe is a vertical .9-m (3-foot) diameter pipe, into which the original surface has dropped (fig. 12). The downhill end is a gently sloping tunnel with a collapsed 
roof (fig. 13). Two additional piping features appear at the top of the slump above Turtle Lake and at the northern Basin Lake drainage on Adobe road (fig. 8). Two of these features occur on highly desiccated colluvial slopes in pre-existing slides. Their lengths range from $2.1 \mathrm{~m}$ ( 7 feet) to approximately $30 \mathrm{~m}$ (100 feet) long. 


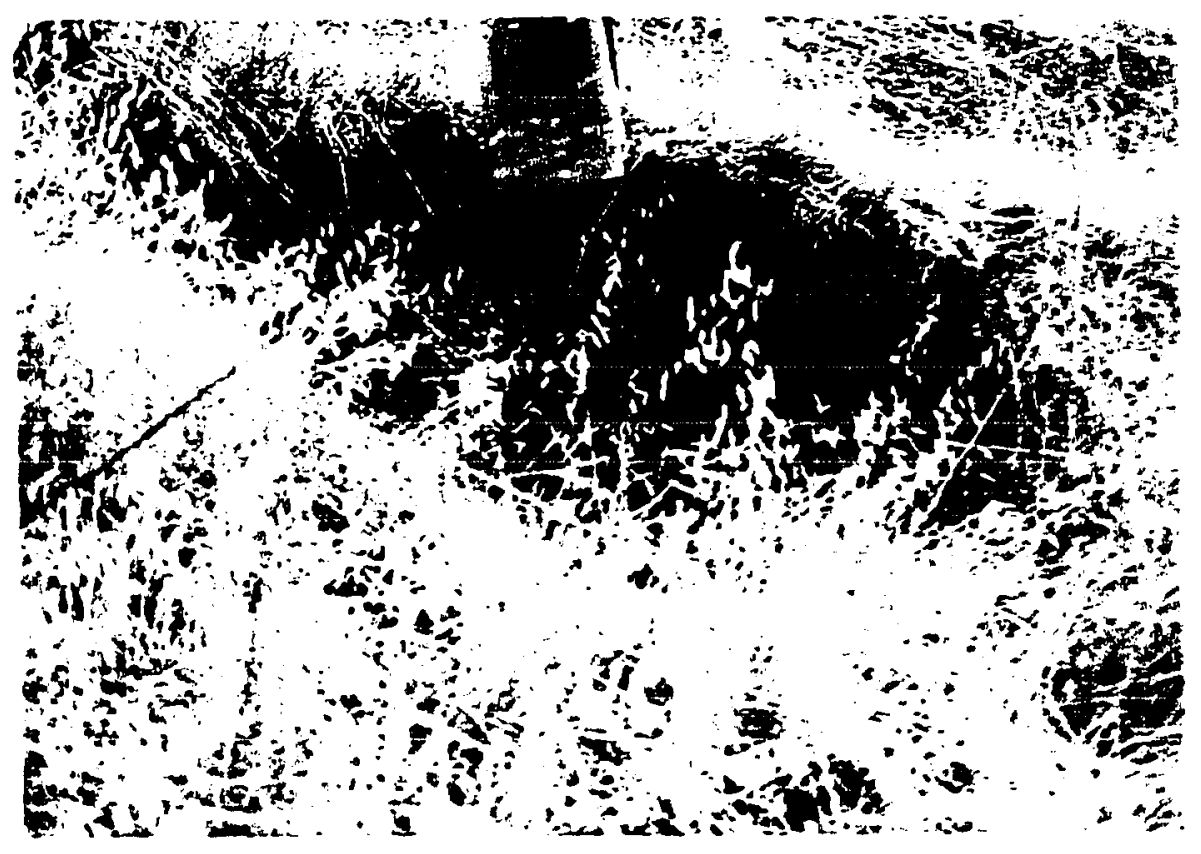

Figure 12. Circular opening of the uplope end of a pipe close to the intersection of Tank and Middlefield Roads (fig. 8). 


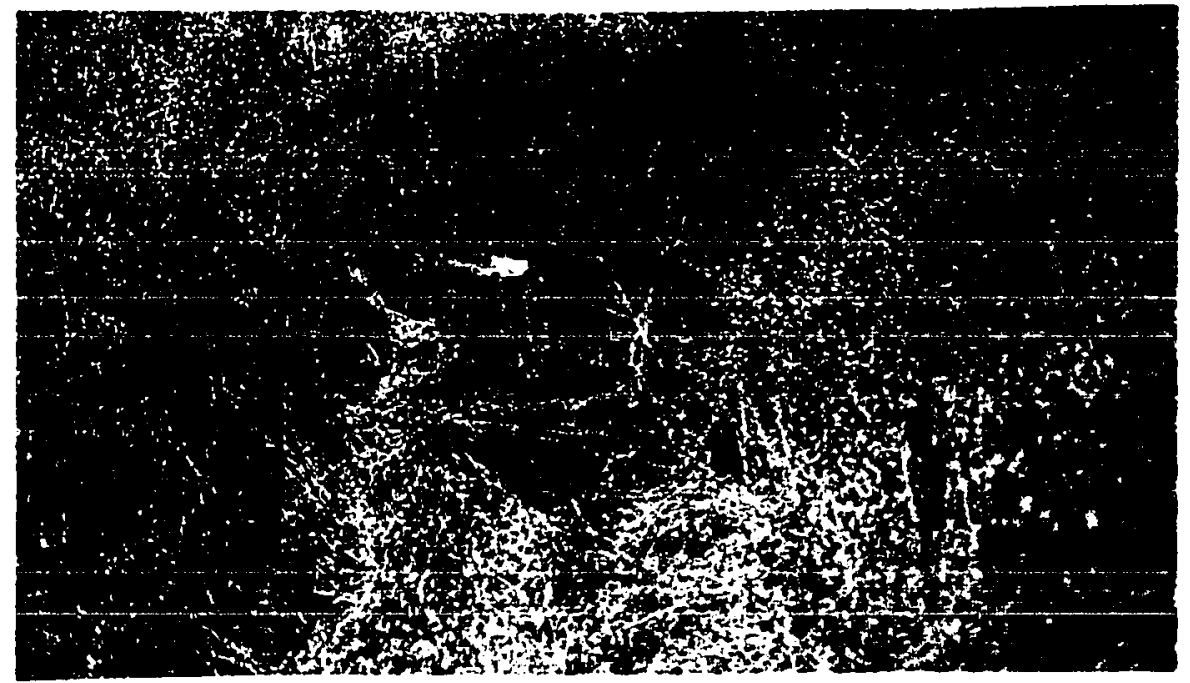

Figure 13. Downslope end of the pipe shown in figure 12. 


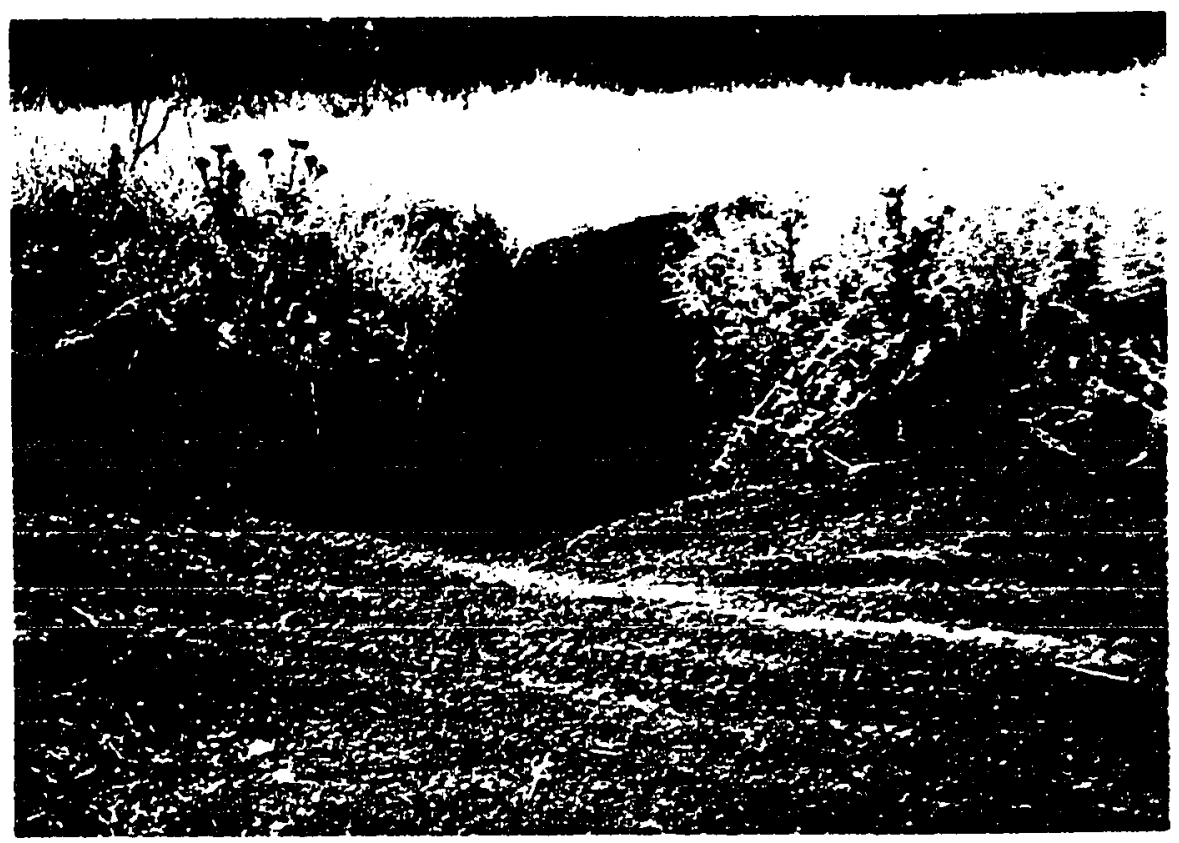

Figure 14. A circular opening of a pipe above Turtle Lake. Pipe is 10 feet in diameter and of undetermined depth.

\section{Gullying}

Gullies are steep-walled, incised, unvegetated, reaches of channels. These are generally sinuous and located in the major drainages in the study area. These features occur in almost all major the drainages in the study area, but are 
best developed in the Renz acquisition. Five of fourteen gullies are located immediately downstream of culverts. There are some examples of smaller discontinuous gullies on south facing slopes in the valley created by the main strand of the San Andreas fault zone. A lower size limit was arbitrarily set at $.3 \mathrm{~m}$ deep and $.3 \mathrm{~m}$ wide. However, gullies in the Renz are as large as $7.5 \mathrm{~m}$ deep by $18 \mathrm{~m}$ across. Gully headwalls are generally vertical. Maximum vertical development of unvegetated head walls and flanks generally occurs immediately downstream from dense networks of oak roots. Some gullies in the area appear to be active, and it is likely that during intense rainfall events surface runoff flows over the lip of the headwall, contributing to headward erosion. It is apparent that the flanks can erode by slumping, because slumps features can be seen in a gully immediately downstream from a culvert on Back springs Road.

The large gully that extends into the valley north of the study area is visible on air photographs and can be traced upstream to beneath the power lines in the southern most drainage in the Renz acquisition. Former landowner Al Renz stated that it was widened considerably during the winter of 1981-1982, following the failure of an unengineered dam in the channel. 
INFLUENCE OF PHYSICAL PARAMETERS ON EROSIVE PROCESSES

\section{Historic Causes}

Physical parameters that influence landslide and fluvial erosion processes can be grouped into two categories: 1) historic causes; and 2) trigger mechanisms. Telfer (1988) defines historic causes as those conditions of geologic materials, slope morphologies, and climates, which are conducive to the formation of landslides.

Triggering mechanisms are those factors which transform a potential slope failure into a landslide in a short period of time. A discussion of triggering mechanisms follows the next section, which discusses historic causes of landslide and fluvial erosion processes in the study area.

\section{slope Morphology}

Steepness: According to Beaty (1956), landsliding in the California Coast Ranges is most common on slopes ranging from 5 to 44 percent. This is generally true for slopes in the study area. However, despite the relative abundance of slopes ranging from 11 to 30 percent, sliding is most common on slopes that ranged in steepness from 31 to 60 percent. of the 103 erosional landforms mapped in the study area, 50 percent of the slides occurred on steep (31-60\%) slopes, which comprised only 20 percent of the study area. Moderate 
(11-30\%) slopes are the most abundant in the study area. Moderate slopes comprise 63 percent of the study area but include only 32 percent of the slides. Piping occurs exclusively on gentle $(0-10 \%)$ slopes. Figure 15 shows the distribution of landslides in the study area. Areas underlying the various slope categories were measured with an electronic planimeter.

Orientation: slope orientation appears to be a factor of less significance than slope steepness in determining the distribution of landslides in the study area. However, some patterns are apparent. There are 103 separate features in the study area. Forty two 42 slump/earthflows, debris slides/avalanches, slumps and rockfalls occur on east-facing slopes, compared to 37 on west-facing slopes. Table 2 indicates a disproportionately large number of inactive debris slides occurring on east-facing slopes. Their occurrence may be attributed to a combination of factors. Mobilization of debris slide/avalanches probably requires a lower energy input than other features in the study area because they primarily involve low strength materials. In addition, drainages on the large number of moister, eastfacing category $3(31-60 \%)$ slopes in the area (Plate 2) provide an ample number of locations for debris sliding/avalanching during a precipitation event. 


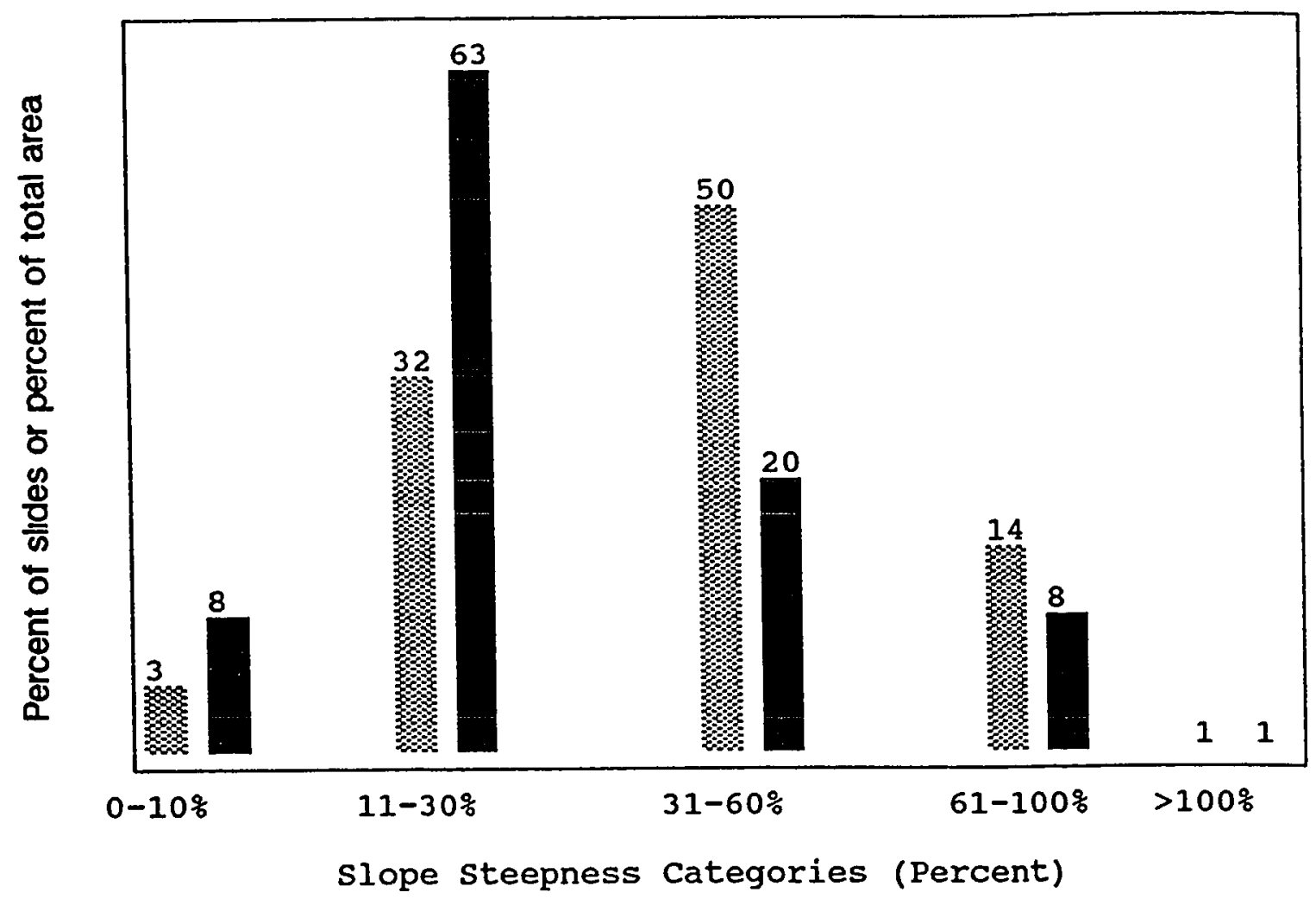

Figure 15. Percentage of slides (stippled bars) occurring in various slope categories (solid bars) in the study area. 
Table 2. Distribution of active and inactive landslides listed by slope aspect and land use category.

Activity

Activit
Level

$\begin{array}{llll}\text { West } & \text { East } & \text { South } & \text { North } \\ \text { Facing } & \text { Facing } & \text { Facing } & \text { Facing }\end{array}$

\begin{tabular}{llllllllll}
$\mathrm{H}$ & $\mathrm{R}^{2}$ & $\mathrm{H}$ & $\mathrm{R}$ & & $\mathrm{H}$ & $\mathrm{R}$ & & $\mathrm{H}$ & $\mathrm{R}$ \\
\hline & Slump/Earth Flows & \\
\hline
\end{tabular}

$\begin{array}{lllllllll}\text { Active } & 1 & 1 & 0 & 3 & 0 & 0 & 1 & 2\end{array}$

Inactive

110

$3 \quad 7$

33

06

Debris slides/Avalanches

$\begin{array}{lrrrrrrrr}\text { Active } & 0 & 1 & 0 & 4 & 0 & 0 & 0 & 0 \\ \text { Inactive } & 2 & 7 & 13 & 12 & 2 & 3 & 0 & 0\end{array}$

\begin{tabular}{|c|c|c|c|c|c|c|c|c|}
\hline \multicolumn{9}{|c|}{ Slumps } \\
\hline Active & 1 & 3 & 0 & 1 & 0 & 1 & 0 & 1 \\
\hline Inactive & 0 & 1 & 0 & 1 & 1 & 0 & 0 & 1 \\
\hline \multicolumn{9}{|c|}{ Rockfalls } \\
\hline Active & 0 & 2 & 0 & 0 & 0 & 0 & & 1 \\
\hline
\end{tabular}

1 Orientation of hillslope with erosional landform.

2 Location of landslide: H HHSVRA, R Renz Acquisition

3 Number of landforms in slope and location category. 
Geologic Materials

In the study area, at least two aspects of the bedrock influence the formation of erosional landforms: 1) zones of weakness in the bedrock; and 2) permeability contrasts. Zones of weakness are present in the bedrock, including fault strands parallel to the San Andreas fault and at least one systematic joint set. These zones of weakness erode more rapidly than other areas. One example of accelerated erosion at a zone of weakness is visible at the junction of Cienega Road and the San Andreas fault zone (Plate 1). At this location, there exists a large-east facing slide, which is bisected by a fault trace. One reason for the large size of this slide may be the presence of highly sheared bedrock where the fault strands intersect the slope.

Pervasive alteration of sandstone and mudstone provides strength and permeability contrasts. Thicker, better indurated sandstone layers that overlie softer mudstone layers may slip, or impermeable layers of colluvium that overlie more permeable layers of bedrock could slip when pore pressures are elevated.

Seventy percent of the mass movement features in the study area have been inactive for decades, perhaps centuries. This suggests that these features may be products of a time 
of more frequent storms of a wetter climate. Growth of these erosional features, now retarded, depends on the periodic occurrence of large storms that are relatively infrequent under the present semi-arid conditions. However, there are erosional features in the study area that occur in dry climates. Piping and gully erosion in the semi-arid southwest have been investigated by Keefer (1971), Antevs (1952), Osborn and Simanton (1986), and Patton and Schumm (1975) and others. Piping in natural environments generally occurs in regions with arid or semi-arid climates. An arid or semiarid climate favors the formation of desiccation cracks and the presence of desiccation cracks promotes piping by allowing water to penetrate rapidly underground (Keefer, 1971). Progressive erosion along narrow subsurface channels is the ultimate result.

Features similar to gullies in the study area were first called arroyos by Kirk Bryan in 1925. These are the vertical-walled, flat-floored channels of ephemeral streams of the semiarid southwest that were greatly enlarged during the 1800s. One postulated cause of arroyo formation is destruction of stabilizing vegetation. Loss of vegetation may permit increased runoff during violent storms creating arroyos in trails ruts, ditches, and stream beds (Antevs, 1952). 
The concepts of arroyo or gully erosion are illustrated in fig. 16. The gully at the top center of the photo is in the Renz property. The gullies appear to originate in the harvested cropland at the top photo composite and may have grown by headward erosion as a result of existing cropland management techniques. Headward erosion as a mechanism of gully growth has been documented by osborn and simanton (1986) . 


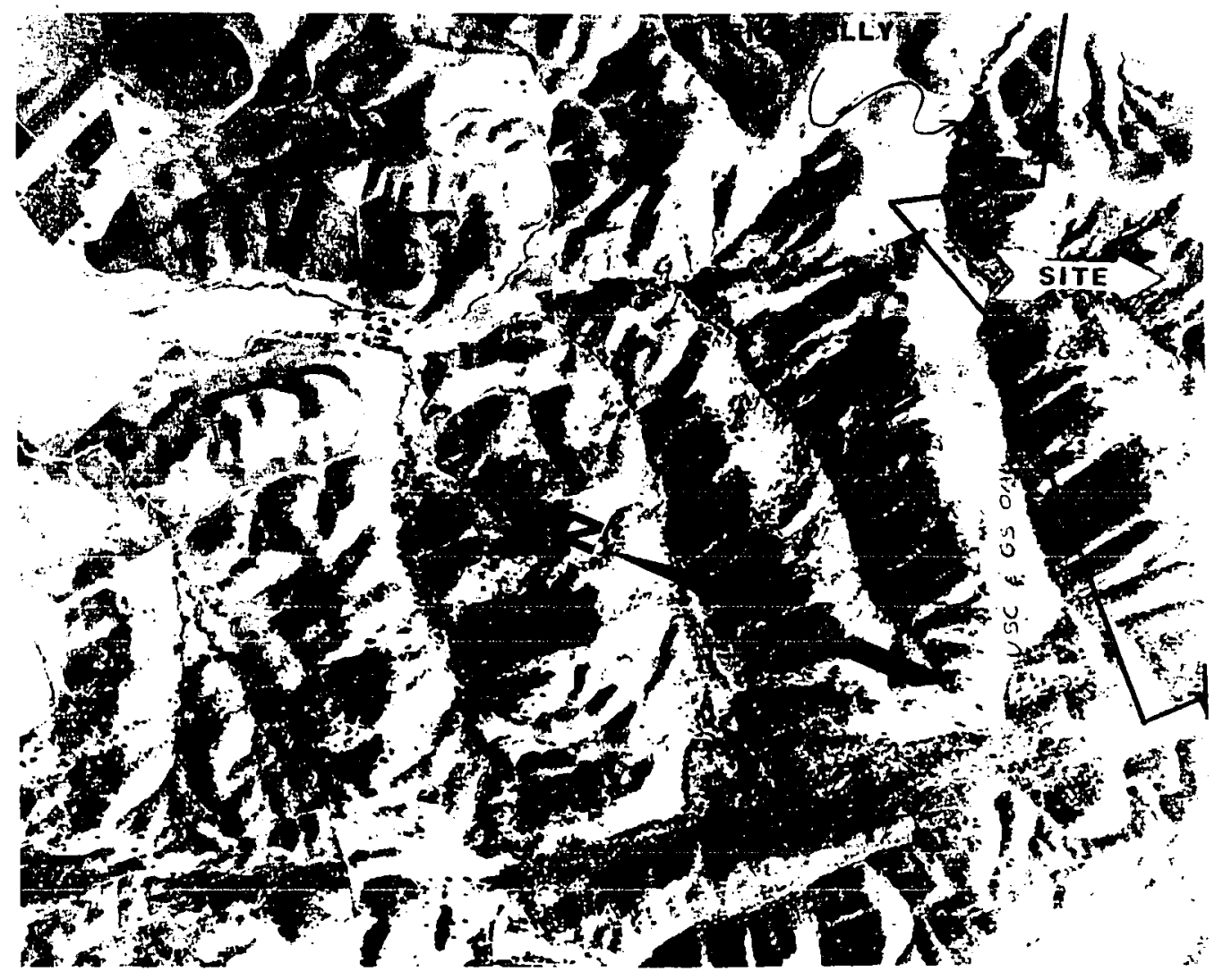

Fig. 16 1:23,750 scale aerial photo (San Benito County, 1947) of the sedimentary terrane surrounding the study area, which is outlined on the right. The Renz gully appears to be a part of a more extensive gully network originating in the farmland to the upper left of the photograph.

However, gullying in low elevations may be reversed at times by sediment input from higher elevations in the study area. 
A good example of this is evident in the valleys north of the study area (Plate 1). Fluvial erosion in the two westernmost drainages in the Renz acquisition is maximized in the highly erodible slump-prone unit in the northern part of the study area (fig 4). Gully dimensions here attain a maximum depth of $7.5 \mathrm{~m}$ and widths of approximately $18 \mathrm{~m}$. In contrast, the drainage closest to Cienega Road, which is underlain by similar bedrock, terminates in an alluviated valley. Aerial photographs clearly show that the source of the valley fill in this drainage is the slump-earthflow complex at the northern boundary of the active portion of SVRA. Therefore, this alluviated valley is in a depositional phase, whereas deep gullies to the west are actively eroding.

\section{Triggering Mechanisms}

Three potential triggering mechanisms operate in the study area: 1) water, 2) removal of basal support, and 3) shocks from seismic events.

\section{Precipitation}

Water may enter the subsurface through desiccation cracks as large as $2.54 \mathrm{~cm}$ and .6 deep during large storm events, elevating pore pressures in the soil and reducing soil 
strength. Research by Nilsen and Turner (1978) indicates that most of the landslides that were triggered in urban areas of Contra Costa County, California occurred during or immediately after storm periods, in which more than $45 \mathrm{~cm}$ of rain fell, particularly if the ground was already wet from previous storms. Amounts of rain required to generate abundant landslides are smaller in the spring than in the fall. They also determined that long periods of relatively continuous rainfall produce more landsliding than short, discrete storms separated by dry periods. Records dating back to 1862 indicate that periods separating large storm events in the Bay Area have varied from 1 to 14 years. Large storm events for the past decade that occurred in 1983 and in 1986. Mobilization of the debris slide pictured in figure 11 resulted from the 1986 storm. It is also reported that slumping on the Cienega Road slide occurred during the 1982-3 storm event, but photographic evidence of this is not available.

\section{Seismic events}

Vibration from seismic events on the nearby active san Andreas fault zone could mobilize unstable slopes in the vicinity. Keefer (1984) profiled slope types that are most susceptible to avalanches because of bedrock instability. They include slopes that are steeper than 25 degrees and 
higher than $135 \mathrm{~m}$, undercut by eroding streams, and composed of intensely fractured rocks. Although slopes at the western boundary of the study area that fit this profile are impacted by avalanches, there is no documentation of earthquake-induced slides in HHSVRA. Furthermore, no changes to slides in the study area were observed as a result of the Magnitude 7.1 Loma Prieta earthquake on october 17, 1989, centered approximately $59 \mathrm{~km}$ (35 miles) northwest of the area. 
Studies by previous authors indicate that motorcycle activity in the HHSVRA alters the physical and chemical properties of soils, resulting in accelerated fluvial erosion (Webb and others, 1978). It has been observed that soils with low infiltration rates have high runoff rates, which provide an opportunity for increased fluvial erosion. However, the effects of ORV traffic on mass movement in the study area remain essentially unevaluated. Subsequently, a series of paired (on-trail and off-trail) infiltrometer tests similar to those by Webb and others (1978) were conducted to quantify the reduction in infiltration on the ORV trails. The method and results of infiltrometer testing in the study area are discussed in the following section.

The infiltration rate is defined as a soil characteristic describing the maximum rate at which water can enter the soil under specified conditions, including the presence of an excess of water (Kirshner, unpublished). 


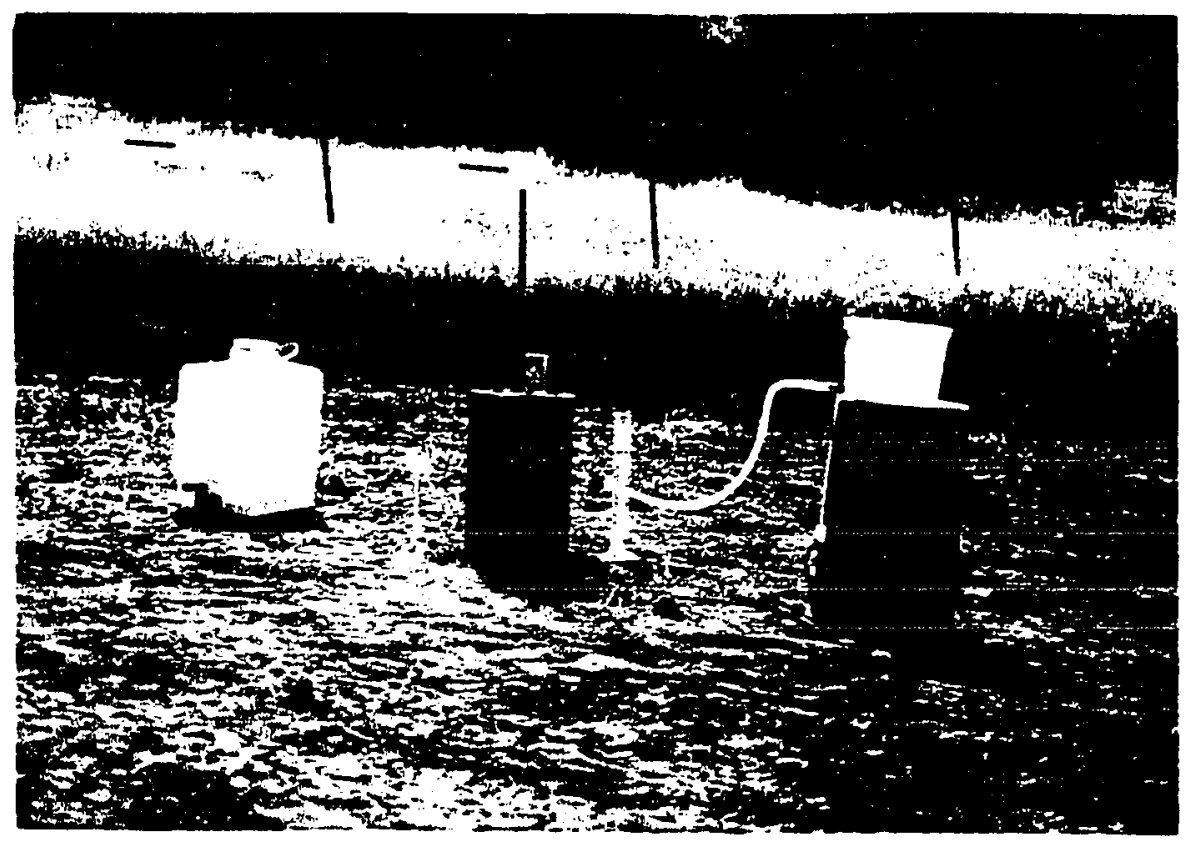

Figure 17. Double ring infiltrometer in the field.

Procedures used to determine surface infiltration rates utilizing the double-ring infiltrometer (fig. 17) were modified from those developed by San Jose graduate student James Kirschner. The design of the infiltrometer complied with the American Society for Testing and Materials (ASTM) specifications and was designated as D3385-75. The 
apparatus consists of two cylinders or rings, one inside the other that are both driven into the ground. The outside diameter of the outer ring is $15 \mathrm{~cm}$ and was constructed from $95 \mathrm{~cm}$ thick steel casing. The inside diameter of the thin inner ring measures $10.8 \mathrm{~cm}$ (fig. 18).

\section{Infiltrometer Testing Procedures \\ Measurement}

1. Using a sledge hammer the small ring is driven $5 \mathrm{~cm}$ into the ground. The large ring is centered around the smaller ring and driven $15 \mathrm{~cm}$ or until refusal into the ground. 2. The test begins immediately after the rings are filled with water to a pre-determined level.

3. Infiltrating water in the inner ring is replaced at timed intervals from a graduated cylinder.

4. The volume of water used from the graduated cylinder is recorded after each timed interval.

5. Water in the outer ring must be maintained at a constant level for the duration of the test.

6. The test is over when a constant volume of water is used for three consecutive timed intervals. 
A.
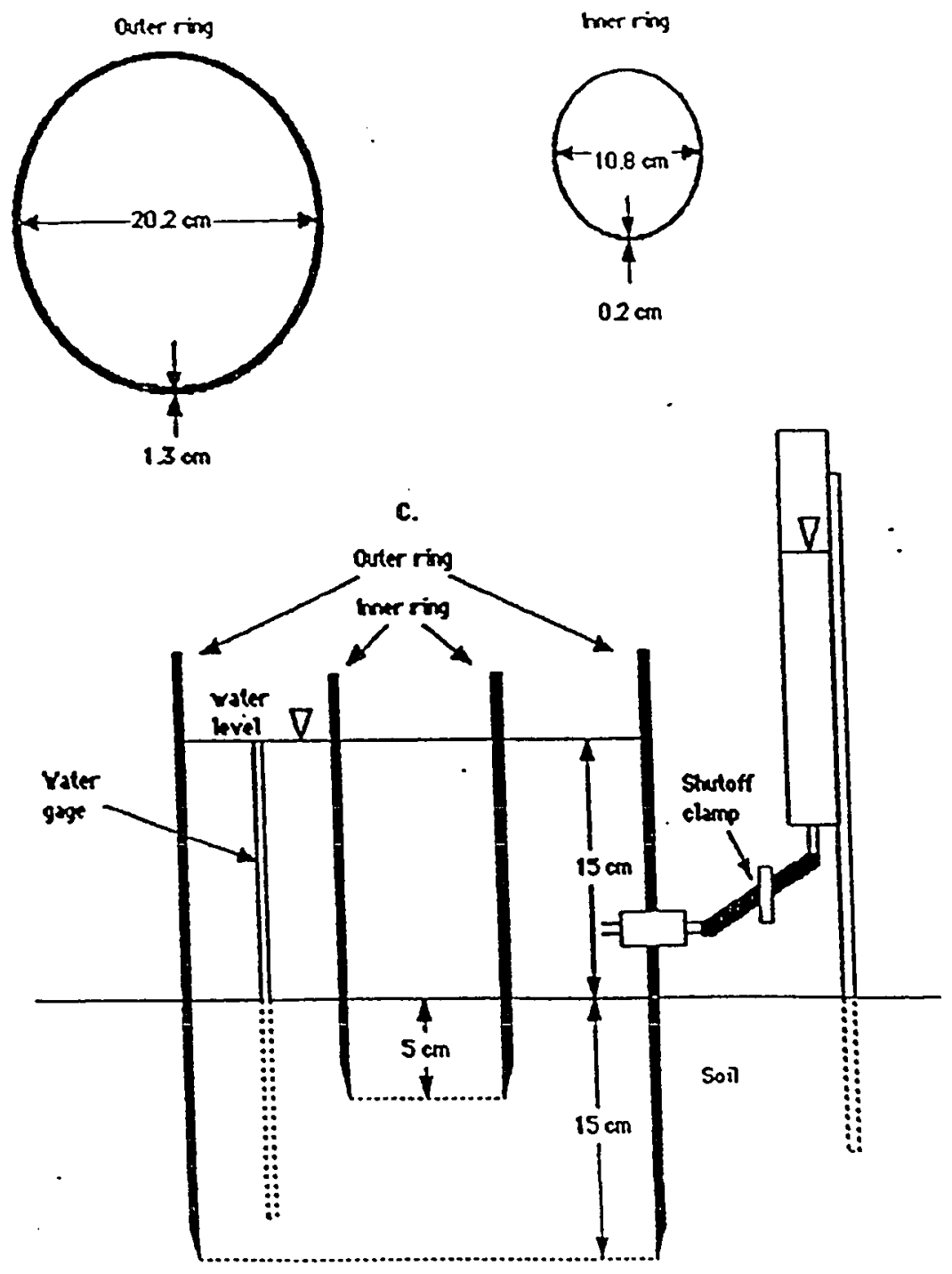

B.

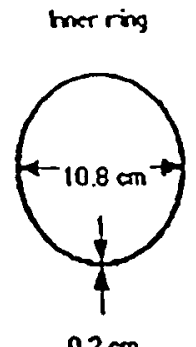

$02 \mathrm{~cm}$

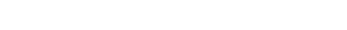

.
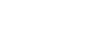


\begin{tabular}{|c|c|c|}
\hline TIME & INFILTRATION & INFILTRATION \\
\hline (MINS) & (ML) & RATE (CM/HR) \\
\hline 0 & & 00 \\
\hline 10 & 340 & 22.3 \\
\hline 20 & 330 & 21.5 \\
\hline 30 & 260 & 17.0 \\
\hline 40 & 170 & 11.1 \\
\hline 50 & 230 & 15.0 \\
\hline 60 & 200 & 13.0 \\
\hline 70 & 200 & 13.0 \\
\hline
\end{tabular}

Table 3. Example of infiltration results.

The double ring configuration of the infiltrometer prevents divergent flow in layered soils by providing an outer water barrier to encourage only vertical flow from the inner ring (Kirschner, San Jose State University, personal communication, 1989). Use of the double ring infiltrometer in the study area was not in compliance with the standard test method because the nature of the highly expansive clays make the test unreliable. Instead, the apparatus was used as a means of comparing the relative surface infiltration rates of adjacent on and off trail sites. Results of infiltrometer tests conducted are summarized in Appendix B.

${ }^{4}$ Infiltration rate $(\mathrm{cm} / \mathrm{hr})=\mathrm{V} *(1 / \mathrm{A}) * 6$, where $1 / \mathrm{A}$ is the inverse area of the inner ring (91.61) and $V$ is the largest volume of water used in a single $10 \mathrm{~min}$ interval during the test. 
Table 4. Summary of infiltrometer results.

\begin{tabular}{|c|c|c|c|}
\hline site & $\begin{array}{l}\text { Slope } \\
\text { Percent }\end{array}$ & $\begin{array}{l}\text { Infiltration } \\
\text { Rate }(\mathrm{cm} / \mathrm{hr})\end{array}$ & Soil Type \\
\hline \multicolumn{4}{|c|}{ On-Trail tests } \\
\hline $\begin{array}{l}61689 \mathrm{~b} \\
51989 \mathrm{~b} \\
6590 \mathrm{~b} \\
61589 \mathrm{~b} \\
11190 \mathrm{~b} \\
6490 \mathrm{~b} \\
111902 \mathrm{~b} \\
64902 \mathrm{~b} \\
65902 \mathrm{~b} \\
61589\end{array}$ & $\begin{array}{r}2 \\
6 \\
11 \\
13 \\
24 \\
24 \\
25 \\
25 \\
30 \\
66\end{array}$ & $\begin{array}{l}4.57 \\
3.07 \\
1.11 \\
5.88 \\
0.33 \\
7.8 \\
0.92 \\
0.26 \\
3.92 \\
21.5\end{array}$ & $\begin{array}{l}\text { Diablo } \\
\text { San Benito } \\
\text { San Benito } \\
\text { Diablo } \\
\text { Diablo } \\
\text { Diablo } \\
\text { Sandy Alluvium } \\
\text { Sandy Alluvium } \\
\text { Nacimiento } \\
\text { Nacimiento }\end{array}$ \\
\hline \multicolumn{4}{|c|}{ off-trail tests } \\
\hline $\begin{array}{l}61689 a \\
51989 a \\
6590 a \\
61589 a \\
11190 a * \\
6490 a \\
111902 a \\
64902 a \\
65902 a \\
11290 *\end{array}$ & $\begin{array}{r}2 \\
6 \\
11 \\
13 \\
24 \\
24 \\
25 \\
25 \\
30 \\
34\end{array}$ & $\begin{array}{l}390.4 \\
64.3 \\
114.45 \\
22.3 \\
35.5 \\
555.9 \\
53.9 \\
74.9 \\
353.3 \\
24.2\end{array}$ & $\begin{array}{l}\text { Diablo } \\
\text { San Benito } \\
\text { San Benito } \\
\text { Diablo } \\
\text { Diablo } \\
\text { Diablo } \\
\text { Sandy Alluvium } \\
\text { Sandy Alluvium } \\
\text { Nacimiento } \\
\text { San Benito }\end{array}$ \\
\hline
\end{tabular}

${ }^{5}$ All soil types from San Benito Soil Survey, 1969. 

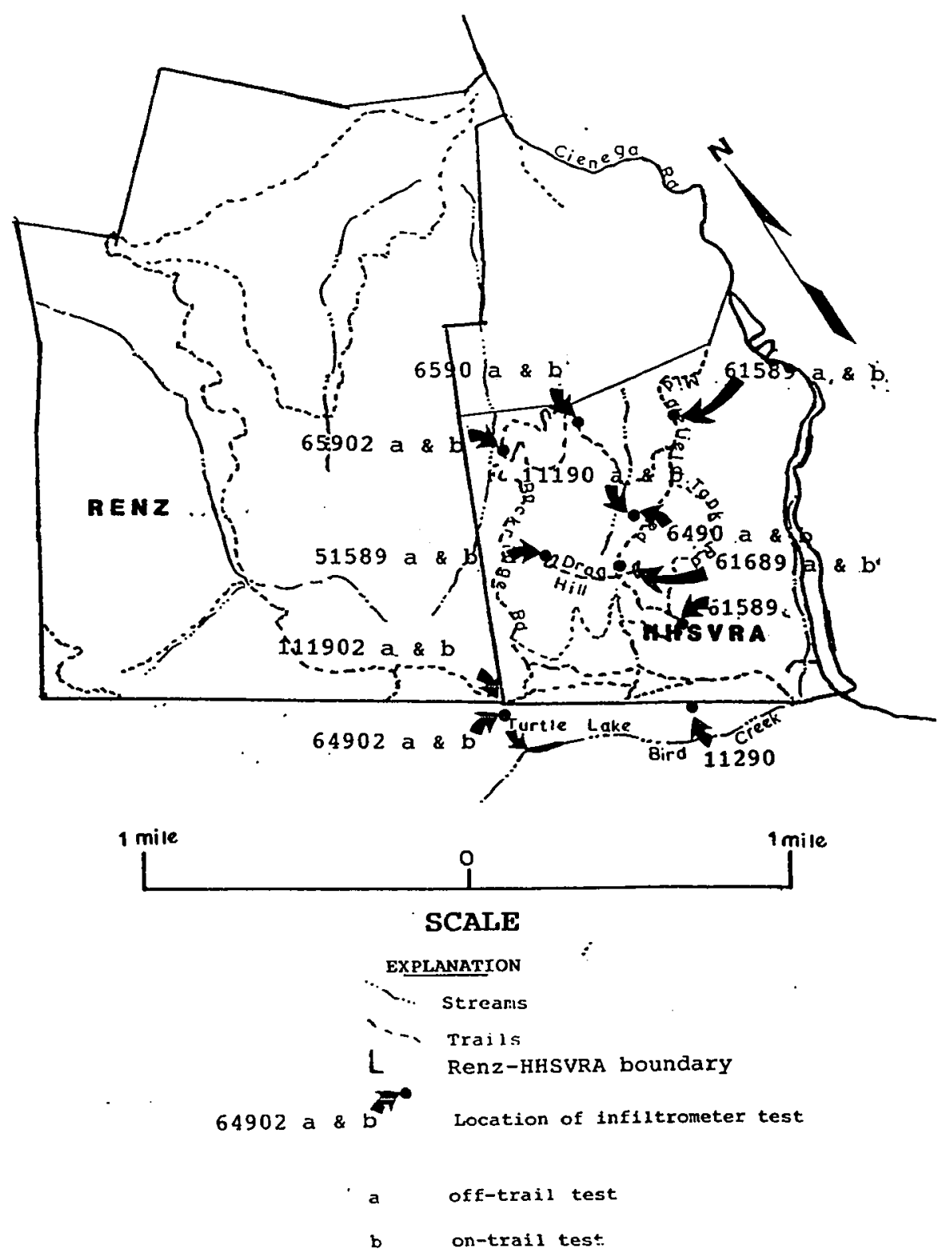

Figure 19. Location of infiltrometer test sites in the study area.

Factors influencing infiltration rates. The average on-trail infiltration rate was $4.93 \mathrm{~cm} / \mathrm{hr}$ and the average 
off-trail infiltration rate $180 \mathrm{~cm} / \mathrm{hr}$. Preliminary field investigation indicates that the primary factor affecting the infiltration rate in the study area is compaction from ORVs. The following are additional factors influencing infiltration rates in the study area:

1) condition of the soil surface.

2) moisture content of the soil.

3) depth to bedrock

4) depth of $A$ horizon

5) soil type

on-trail soils were examined to a shallow depth during a motorcycle test by Harden and Williams (1989). A portion of an active trail and the adjacent vegetated area (off-trail) was trenched to a depth of $.3 \mathrm{~m}$. The on-trail ground surface is dry, unvegetated, and displays desiccation cracks approximately $.5 \mathrm{~cm}$ wide and $3.8-7.5 \mathrm{~cm}$ long. In the subsurface cracks in both areas are equally deep, with many of them greater than the depth of the trench. However, the on-trail cracks are sealed to a depth of approximately $1 \mathrm{~cm}$ inches by clayey soils forced into the cracks by motorcycle activity. Efforts at penetrating the upper $10 \mathrm{~cm}$ of the trench with the point of a staedtler $.5 \mathrm{~mm}$ mechanical pencil proved unsuccessful. The lower $20 \mathrm{~cm}$ of the trench was penetrable by the pencil. Desication cracks on the off- 
trail ground surface are partly sealed during the wet season. Although they are approximately the same lengths as the cracks on drag hill, their widths are narrower, ranging from .25-1 cm. The soil is less granular and more plastic. Increased moisture content in the soils appears to decrease the secondary permeability by sealing desiccation cracks as clay particles expand.

Higher soil moisture contents apparently decrease infiltration rates. Therefore, comparative double ring infiltrometer tests should be conducted when expansive soils are in similar conditions of soil moisture. Predictably, tests run during the wet season indicated lower infiltration rates for the off-trail sites; no significant seasonal differences existed for the on-trail sites. Early infiltrometer tests (beginning with number 1) were conducted during the wet season. These tests showed lower rates at on-trail and off-trail sites. Lower rates were influenced by antecedent moisture because a number of these tests were conducted during or immediately following rainfall. slope steepness and density did not appear to influence the test results.

ORV activity at the crest of Competition Hill has stripped the soil to bedrock (fig. 5). This exposed a sandstone that 
is generally more permeable than compacted clay. In the exposed sandstone, driving the infiltrometer was more difficult and resulted in cracking of the ground. This cracking artificially increased the rate of infiltration by increasing the secondary permeability. Consequently, the infiltration rate of test \# 61589 (Appendix 1) was much higher than the other on-trail sites, which were in clay.

The undisturbed uppermost soil horizons in the study area are generally composed of loosely compacted decaying organic matter, possibly made even more porous by bioturbation. Tests in this soil layer may yield high infiltration rates.

The Diablo soil series yielded three of the four highest test results in the study area. The same soil series also yielded the lowest wet test result (Table 4). This is contrary to results from H.T. Harvey and Associates (1989), in which the Diablo soil series yielded the lowest permeability rating of the soils present in the study area. Reasons for this disparity are unknown. 
Active and inactive slides are being impacted by ORV traffic throughout the study area. Evidence of this is visible at Competition Hill, Psych Hill, and the slide above Turtle Lake (fig. 8), where active scarps have been impacted by motorcycle tracks. Infiltration tests at Competition Hill and Turtle Lake indicate decreased on-trail infiltration rates on these slides.

Historic aerial photos, and a detailed survey of the active part of the study area and the Renz acquisition have failed to uncover evidence proving that ORV activity has had a major effect on the large pre-existing erosional landforms that cover 22 percent of the study area.

In order to compare landslide distribution in these two areas, the following equations were used in determining landslide activity in the study area.

Percent of active slides $=\frac{\text { total area of active slides }}{\text { total area of all slides }} * 100$

Ratio of active gullies $=\frac{\text { miles of gullied stream }}{\text { total stream miles }}$ 
Analysis of the landslide map shows that 10.9 percent of the slides in the Renz acquisition are active. Only 0.8 percent of the total landslide area in the HHSVRA is active. The difference in the occurrence of active gullies in the adjacent study areas is much less dramatic. In the Renz acquisition, 42 percent or 3.6 of $8.8 \mathrm{~km}(2.3$ of 5.5 miles) of streams are affected by active gullies. By contrast, only 26 percent of all streams in HHSVRA (1 of $4.32 \mathrm{~km}$ ) (.7 miles of 2.7 miles of streams) were gullied (Table 5).

Table 5. Percent of active features in area.

Active Slides

Active Gullies

$\begin{array}{lrr}\text { Renz } & 10.9 \% & 42 \% \\ \text { HHSVRA } & 0.8 \% & 26 \%\end{array}$

Although additional fluvial erosion (piping) is evident on the landslide above Turtle Lake, ORV traffic does not appear to be significantly impacting mass movement. one additional debris avalanche on the last east-facing slope in the study area appears on the 1988 photographs. Eyewitness accounts by former landowner Al Renz associate the initiation of this slide with the storms during 1986. 
SUMMARY AND CONCLUSIONS

Mapped erosional features include both mass movement and fluvial erosional landforms. The mass movement features consist of four landslide types: 48 slump/earthflows; 40 Debris Slide/Avalanches; 14 Slumps and 2 Rock Falls. Seventy percent of these features are inactive. Fluvial erosional landforms include 4 piping features and 6 separate, continuous gullies.

The study area is underlain primarily by the PlioPleistocene aged Etchegoin formation. A probable fault contact with a second, unnamed unit is visible on $1: 40,000$ scale air photos approximately one mile north of the san Andreas fault zone. Both units are composed of marine and non-marine, poorly consolidated, micaceous interbedded sandstone and mudstone. However, the unnamed unit, which weathers to a very erodible soil belonging to the Diablo Series, is more erodible, as indicated by disproportionately high number of slump/earthflows in the area underlain by the unnamed unit.

Infiltrometer studies in the active HHSVRA show that average on-trail infiltration rates are $4.93 \mathrm{~cm} / \mathrm{hr}$, whereas average off-trail rates were $180 \mathrm{~cm} / \mathrm{hr}$. The results indicate that the potential for increased fluvial erosion exists on ORV- 
taken at intervals from 1947 to 1988 shows no significant change in the distribution of erosional landforms in the area impacted by motorcycle traffic. In fact, a comparison of activity levels of landslides and gullies on HHSVRA and the adjacent Renz Acquisition indicates that 26 percent of all streams in the portion of HHSVRA included in this study are gullied. In contrast, 42 percent of the total stream length in the adjacent Renz acquisition is gullied. Almost 11 percent of the slides in the Renz are active. In contrast less than one (1\%) percent of the slides in the actively used portion of the HHSVRA are active.

Higher landslide density in the Renz acquisition can be attributed in part to the underlying bedrock. A greater number of slopes in the Renz acquisition are located in large north-facing drainages, These north-facing drainages appear more susceptible to gully erosion, which may facilitate mass movement by undercutting the slopes. The large drainages originate in the unnamed unit, which appears to be more erodible than the Etchegoin formation and, which underlies a greater portion of the Renz acquisition than the active HHSVRA.

Slope steepness is also an important factor controlling 
landslide distribution in the study area. Of the 103 erosional landforms mapped in the study area, 50 percent of the slides occurred on steep (>31\%-60\% slopes) slopes, which comprised only 20 percent of the study area. Moderate slopes constitute 63 percent of the study area, but are impacted by only 32 percent of the slides. Forty one percent of all slides occur on east-facing slopes, while 36 percent occur on west-facing slopes.

ORV traffic has resulted in obvious scars on slopes in the study area. These scars are produced by mechanical erosion of the soil by motorcycle tires. The scars are deepened by fluvial erosion resulting from increased runoff during rainfall. However, preliminary results of this paired area study indicate that the predominant factors governing the position of the large erosional landforms are geologic materials, slope morphology, and the existing landslide activity;. The principal factor responsible for initiating landslide movement apparently large storms or wetter climate cycles. Although ORV activity has resulted in erosion at HHSVRA, formation of large erosional landforms currently can be attributed to the factors mentioned above. Further study is necessary to determine whether continued ORV use would affect the distribution of the large erosional landforms. 
RECOMMENDATIONS FOR FURTHER STUDY

Several questions remain pertaining to erosion in the study area. It was not the author's intent to address the following topics as part of the study. However, information gained from the following topics would contribute valuable information to the study of erosion in HHSVRA.

The first unanswered question is: Has decreased infiltration on the trails changed the overall infiltration at HHSVRA and if so, by how much? Despite results by earlier workers (Webb, 1980; Harden, 1990), which indicate that sediment loss is greater on slopes impacted by ORV traffic, preliminary results from this study indicate that mass movement and fluvial erosional landforms are less common on ORV-impacted slopes. This suggests that other factors such as geology, slope steepness, or grazing activity may be important factors.

Secondly, is there a possibility of increased gully expansion into the valley north of the study area where a number of private homes are located, below the Renz acquisition following ORV traffic in the Renz Acquisition? If so, what effective mitigative options exist in HHSVRA? 
The answers to these questions depend on the accumulation and analysis of additional data from the field area and further research into the existing literature on erosion. Additional infiltrometer tests should be implemented in order to properly calibrate the apparatus. Landslide data should be analyzed further for answers on occurrence of erosional landforms in the study area.

Transects at the sites of future trails and active gullies in the Renz acquisition could be monitored to detect changes in sediment volume. Data gathered from the transects would permit more accurate evaluation of on-trail erosion and of gully erosion rates. 
Adegoke, O. S., 1969, stratigraphy and paleontology of the marine Neogene formations of the coalinga region, California: University of California publications in Geological Sciences, v. 80,269 p.

Anderson, F. M., 1905, Stratigraphy study of the Mount DiabloRange of California: California Academy of Sciences, Proceedings 3rd series, v. 3, p. 1-40.

Antevs, Ernst, 1952, Arroyo-cutting and filling: Journal of Geology, v. 60, p. 375-385.

Beaty, C.B., 1956, Landslides and slope exposure: Journal of Geology, v. 64, p. 70-74.

Blanc, R. P., and Cleveland, G.B., 1979, Natural slope stability as related to geology, San clemente area, Orange and San Diego Counties California: California Division of Mines and Geology, Special Report 98, 19 p.

Calloway, R. A., Roberts, M. H., Hiele, J. L., and Pierce, K. H., 1978, Hollister Hills State Recreation Area Resource Management Plan, General Development Plan and Environmental Impact Report: unpublished, 127 p.

Compton, R.R., 1968, Granitic and metamorphic rocks of the Salinian Block, California Coast Ranges: California Division of Mines and Geology, Bull. 190, p. 277-287.

Dibblee, T.W., 1980, Geology along the San Andreas Fault from Gilroy To Parkfield, California: California Division of Mines and Geology, SR 40, p. 3-17.

Dibblee, T. W., 1973, Stratigraphy of the southern coast Ranges near the San Andreas fault from Cholame to Maricopa, California: U.S. Geological Survey Professional Paper 764, $45 \mathrm{p}$.

Harden, D. R., Janda R. J., and Nolan K. M., 1976, Erosional landform map of the Redwood Creek Basin, Humboldt County, California: U.S Water Resources Investigation open-file Map 76-42, scale 1:62,500. 
Harden, D. R., and Taylor, B. E., 1990, Studies of Erosion and sediment transport, Hollister Hills State Vehicular Recreation Area: unpublished report prepared for the California Department of Parks and Recreation, $30 \mathrm{p}$.

Harden, D. R., and Williams, J. W., 1989, Mechanical erosion by off-road motorcycles on hillslope trails, Hollister Hills state Vehicular Recreational area, California: Association of Engineering Geologists, Annual Meeting, Abstracts with Programs.

Harvey \& Associates; Ecological Consultants, Alviso, Ca., 1989, Environmental Impact Report For The Hudner Ranch Acquisition And Addition To Hollister Hills SVRA., File 523-01, unpublished.

Jones, S., 1988, study of the ecological effects of off-road vehicles at Hollister Hills state Vehicular Recreation Area, Hollister, California: San Jose State University unpublished M.S. Thesis, 54 p.

Keefer, D. K., 1984, Rock avalanches caused by earthquakes: source characteristics: Science, vol. 223, p. 1288-1290.

Keefer, D. K. 1971, Gully formation on the Gravantz-Beffa Hill: Stanford University, unpublished student report, p. 70-73.

Perkins, J.A., 1987, Provenance of the Upper Miocene and Pliocene Etchegoin Formation: Implications for paleogeography of the late Miocene of Central California: U.S. Geological Survey, Open-File Report 87-167, p. 1-65.

Nason, R.D., 1971, Investigation of fault creep slippage in northern and central California: dissertation, University of California at San Diego unpublished $\mathrm{Ph}$. D. dissertation p. 38-71.

Nilsen, T.H., and Turner, B.L., 1978, Influence of rainfall and ancient landslide deposits on recent landslides (1950-71) in urban areas of Contra Costa county, California: U.S. Geological Survey Bulletin No. $1388,18 \mathrm{p}$.

Osborn, H.B., and Simanton, J.R., 1986, Gully migration of a Southwest rangeland watershed: Journal of Range Management, vol. 39, No. 6, p. 558-561. 
Plafker, G. and Galloway, J. P., 1989, Lessons learned from the Loma Prieta Earthquake of October 17, 1989: U. S. Geological Survey Circular 1045 p. 4.

Patton, P.C., and Schumm, S.A., 1975, Gully erosion, northwestern California: a threshold phenomenon: Geology, p 88-90.

Rogers, T.H., 1980, Geology and seismicity at the convergence of the San Andreas and Calaveras Fault Zones near Hollister, San Benito County, California: California Division of Mines and Geology, SR 140, p 19-27.

Rogers, T. H., unpublished, Geology of the Hollister and San Felipe quadrangles, San Benito, Santa Clara, and Monterey counties, California: California Division of Mines and Geology, scale 1: 24,000

Sarna-Wojcicki, A. M., Pampeyan, E. H., Hall, and T. N., 1975, Map showing recently active breaks along the San Andreas Fault between the Central Santa Cruz Mountains and the Gabilan Range, California: Miscellaneous field inventory map, U.S. Geological Survey, MF-650, scale $1: 24,000$.

Schuster, R. L., and Krizek, R. J. (eds) 1978, Landslides: analysis and control: National Academy of Sciences, Washington D. C., Special Report Transportation Research Board, National Research Council, S.R. 176.

Smith, J. P., 1916, The Geologic Formations of California: California state Mining Bureau, Bulletin No 72, p38.

Snyder, C. T., Frickel, D. G., Hadley, R. F. and Miller, R. F., 1976, Effects of off-Road Vehicle use on the hydrology and landscape of arid environments in central and southern California: U.S. Geological Survey WaterResources Investigation $76-99,30 \mathrm{p}$.

Taliaferro, N. L., 1945, Geologic Map of the Hollister Quadrangle, California: California Division of Mines Bulletin 143. pl 1, (unpublished).

Telfer, A.L., 1988, Landslides and land use planning: U. S. Geological Survey Bull. No. 63, 64 p.

Varnes, D. J. (ed) 1978, Slope Movement Types and Processes, Landslides: analysis and control, National Academy of Sciences:, Washington D. C., Special Report 
Transportation Research Board, National Research Council, Special Report. 176.

U.S. Department of Agriculture Soil Conservation Service in cooperation with University of California Agricultural Experiment Station., 1969, Soil Survey San Benito County California: p. 25 and 19 .

Webb, R.H., Ragland, C.H., Godwin, W.H. and Jenkins, D., 1978, Environmental effects of soil property changes with Off-Road Vehicle Use: Environmental Management, vol. 2, No. 3, p. 219-233

Wilshire, H. G., 1977, Study Results of 9 sites used by off-road vehicles that illustrate land modifications, $U$. S. Geological Survey, Open-File Report 77-601, 22 p.

Wilshire, H.G., Nakata, J. K., and Prestegaard, K., 1978, impacts of vehicles on natural terrain at seven sites in the San Francisco Bay Area: Environmental Geology, vol. 2, No. 5, p. 295-319. 
AERIAL PHOTOGRAPHS

Hollister Hills SVRA, state of California Department of Water Resources, Wester Aerial Photos, Contract No. Wild RC 10, color, dated June 131988 , scale 1:40,000.

Hollister Hills SVRA, State of California Department of Water Resources, Wester Aerial Photos, Contract No. Wild RC 10, color, dated June 10, 1988, scale 1:6000.

Hollister Hills SVRA, State of California Department of Water Resources, Genge Aerial Survey, Contract No. WRDPR-AIU-C, dated May 31, 1979, scale 1:6000.

Monterey Mapping Project, U. S. Geological Survey, Contract No. GS-VDDI, black and white, dated April 18, 1973, scale $1: 80,000$.

unknown title, San Benito County, California, Fairchild Aerial Surveys Inc., black and white, dated November 23 1947, scale 1:11,800.

unknown title and agency, Property of the Department of Parks and Recreation, color infrared, dated May 14, 1985, scale 1:6,000. 


\section{APPENDIX A-FIELD INVESTIGATION}

The double Ring infiltrometer was utilized for all infiltration tests in the study area. The resulting infiltration rate for each test is considered to be the timed interval, in which the largest volume of water percolates into the ground. All site numbers are located on figure 17. The listed data following each site number represents a single test.

SITE \# 51989A

LOCATION On Drag Hill, grassy area north of test track.

REMARKS hot day, ground surface desiccated and vegetated with grasses. slope $=6 \%$

TIME (MIN) VOLUME (MLS) RATE (CM/HR)

$\begin{array}{lll}0 & 0 & 0 \\ 10 & 885 & 64.31 \\ 20 & 458 & 27.23 \\ 30 & 136 & 8.894 \\ 40 & 139 & 9.025 \\ 50 & 139 & 9.025\end{array}$




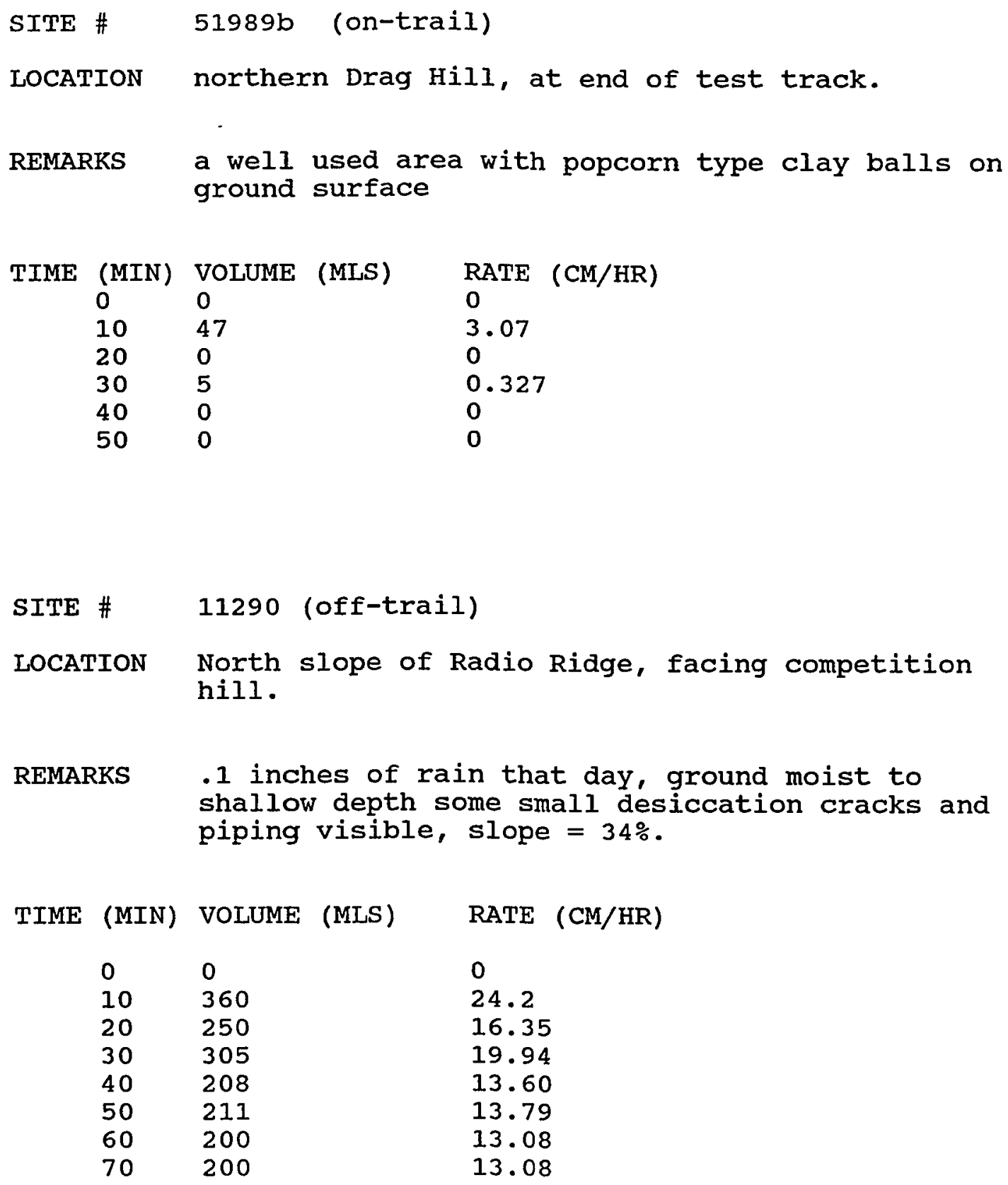

$\begin{array}{lll}0 & 0 & 0 \\ 10 & 360 & 24.2 \\ 20 & 250 & 16.35 \\ 30 & 305 & 19.94 \\ 40 & 208 & 13.60 \\ 50 & 211 & 13.79 \\ 60 & 200 & 13.08 \\ 70 & 200 & 13.08\end{array}$




$\begin{array}{lll}\text { SITE \# } & 61589 \text { (on-trail) } \\ \text { LOCATION } & \text { Crest of super hill by } \\ & \\ \text { REMARKS } & \text { soil stripped to sands } \\ & \text { during installation of } \\ & & \\ \text { TIME (MIN) } & \text { VOLUME (MLS) } & \text { RATE } \\ & & \\ 10 & 0 & 0 \\ 20 & 200 & 21.5 \\ 30 & 200 & 13.08 \\ 40 & 200 & 13.08 \\ 50 & 205 & 13.08 \\ 60 & 205 & 13.40 \\ 70 & 205 & 13.40 \\ & & 13.40\end{array}$

\section{SITE \# 111902a (off-trail)}

LOCATION opposite 2 way road sign above Turtle lake slide

REMARKS expandable clays, some cracks visible, partially vegetated recovering ground, 25\% slope.

TIME (MIN) VOLUME (MLS) RATE (CM/HR)

$\begin{array}{lll}0 & 0 & 0 \\ 10 & 818 & 53.49 \\ 20 & 325 & 21.25 \\ 30 & 300 & 19.52 \\ 40 & 260 & 17.0 \\ 50 & 215 & 14.06 \\ 60 & 207 & 13.53 \\ 70 & 200 & 13.08 \\ 80 & 200 & 13.08 \\ 90 & 200 & 13.08\end{array}$




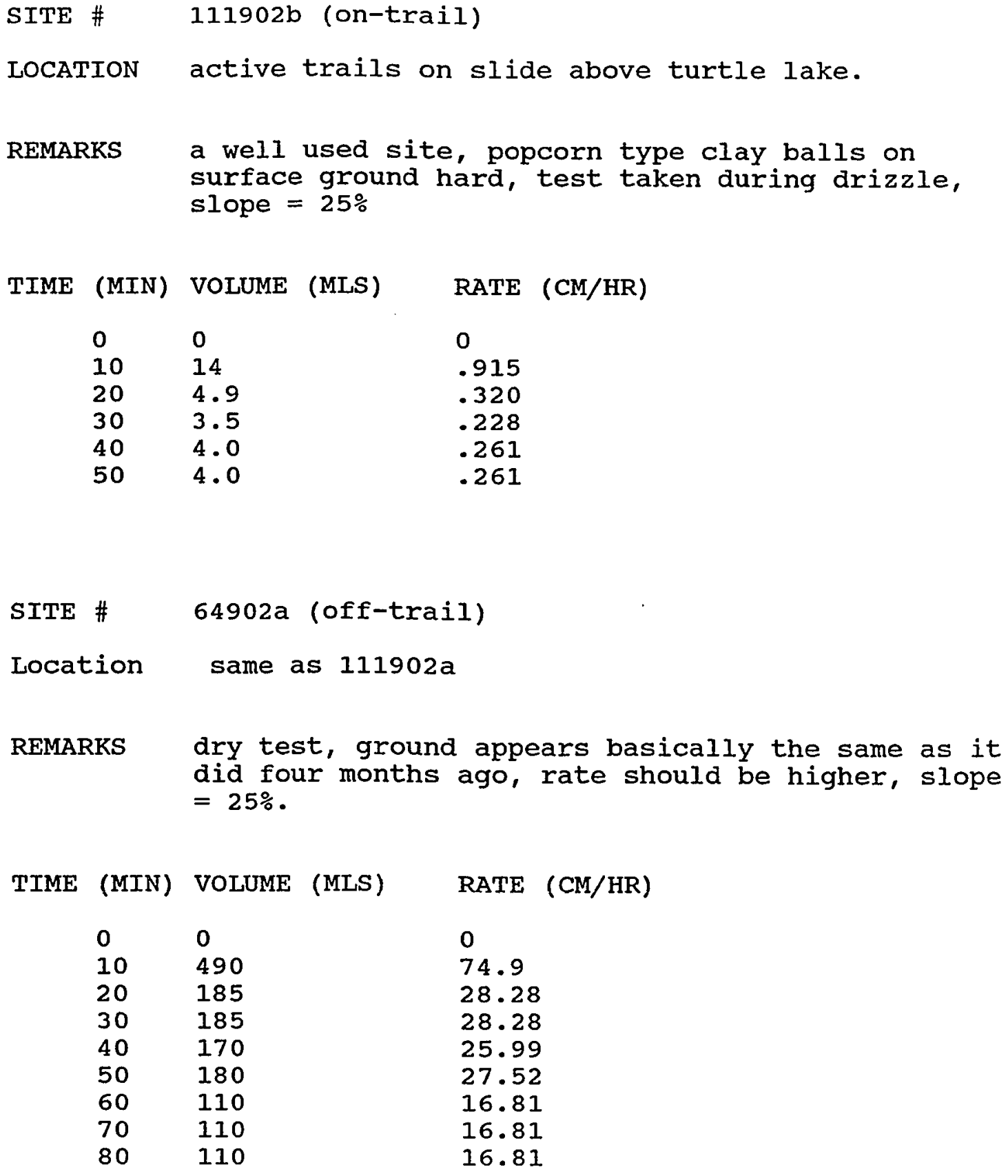
did four months ago, rate should be higher, slope $=25 \%$.

TIME (MIN) VOLUME (MLS) RATE (CM/HR)

$\begin{array}{lll}0 & 0 & 0 \\ 10 & 490 & 74.9 \\ 20 & 185 & 28.28 \\ 30 & 185 & 28.28 \\ 40 & 170 & 25.99 \\ 50 & 180 & 27.52 \\ 60 & 110 & 16.81 \\ 70 & 110 & 16.81 \\ 80 & 110 & 16.81\end{array}$




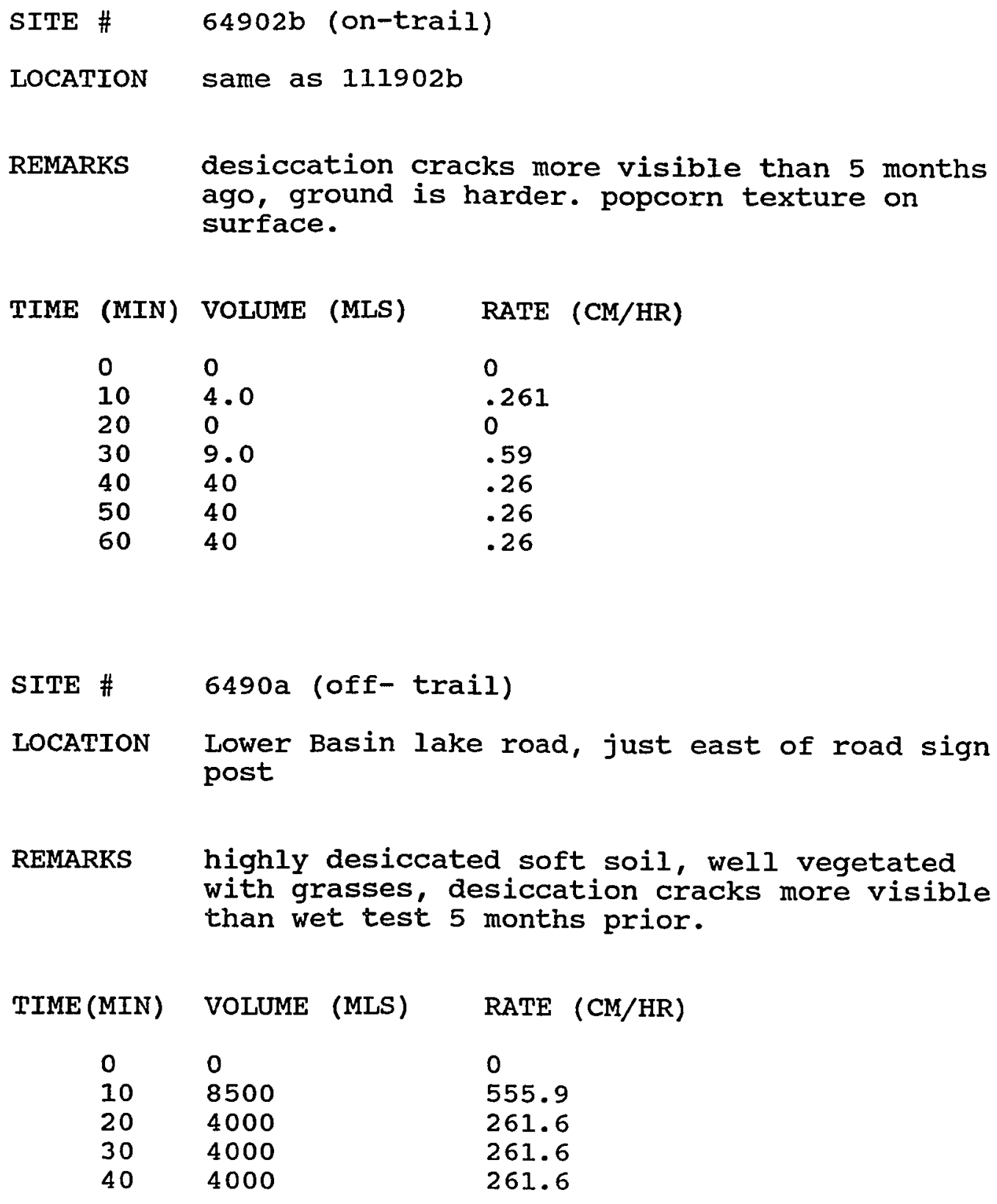

$\begin{array}{lll}0 & 0 & 0 \\ 10 & 4.0 & .261 \\ 20 & 0 & 0 \\ 30 & 9.0 & .59 \\ 40 & 40 & .26 \\ 50 & 40 & .26 \\ 60 & 40 & .26\end{array}$

SITE \# 6490a (off- trail)

LOCATION Lower Basin lake road, just east of road sign post

REMARKS highly desiccated soft soil, well vegetated with grasses, desiccation cracks more visible than wet test 5 months prior.

TIME (MIN) VOLUME (MLS) RATE (CM/HR)

$\begin{array}{lll}0 & 0 & 0 \\ 10 & 8500 & 555.9 \\ 20 & 4000 & 261.6 \\ 30 & 4000 & 261.6 \\ 40 & 4000 & 261.6\end{array}$




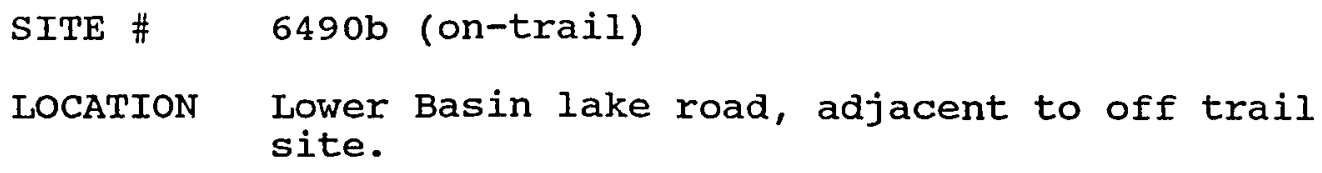

REMARKS ground looks basically the way it did during wet test but surface feels harder.

$\begin{array}{lll}\text { TIME (MIN) } & \text { VOLUME (MLS) } & \text { RATE } \\ 0 & 0 & \\ 10 & 120 & 7.8 \\ 20 & 90 & 5.8 \\ 30 & 69 & 4.51 \\ 40 & 63 & 4.12 \\ 50 & 50 & 3.27 \\ 60 & 65 & 4.25 \\ 70 & 65 & 4.25\end{array}$

SITE \# 11190a (off-trail)

LOCATION same as $6490 a$

REMARKS desiccation cracks more visible than during wet test, ground well vegetated with dry grass. slope $24 \%$

TIME (MIN) VOLUME (MLS) RATE (CM/HR)

$\begin{array}{lll}0 & 0 & 0 \\ 10 & 543 & 35.51 \\ 20 & 450 & 29.43 \\ 30 & 410 & 26.81 \\ 40 & 330 & 21.58 \\ 50 & 370 & 24.19 \\ 60 & 320 & 20.92 \\ 70 & 320 & 20.9 \\ 80 & 320 & 20.92\end{array}$




$\begin{array}{cll}\begin{array}{l}\text { SITE \# } \\ \text { LOCATION }\end{array} & \begin{array}{l}\text { s1190b (on-trail) } \\ \text { same as } 6490 \mathrm{~b}\end{array} \\ \text { REMARKS } & \begin{array}{l}\text { ground muddy but no } \\ \text { of test, desiccation }\end{array} \\ & & \\ \text { TIME (MIN) } & \text { VOLUME (MLS) } & \text { RATE } \\ & & \\ 10 & 0 & 0 \\ 20 & 5 & .327 \\ 30 & 5 & .327 \\ 40 & 5 & .327 \\ 50 & 5 & .327 \\ .327\end{array}$

$\begin{array}{ll}\text { SITE \# } & 61689 a \text { (off-trail) } \\ \text { LOCATION } & \begin{array}{l}\text { Hill top on Middlefield road on east end of Drag } \\ \text { Hill }\end{array}\end{array}$

REMARKS site sparsely vegetated with dry grasses, wide desiccation cracks visible.

TIME (MIN) VOLUME (MLS) RATE (CM/HR)

$\begin{array}{lll}0 & 0 & 0 \\ 10 & 5970 & 390.4 \\ 20 & 1370 & 89.5 \\ 30 & 625 & 40.8 \\ 40 & 610 & 39.9 \\ 50 & 610 & 39.9\end{array}$




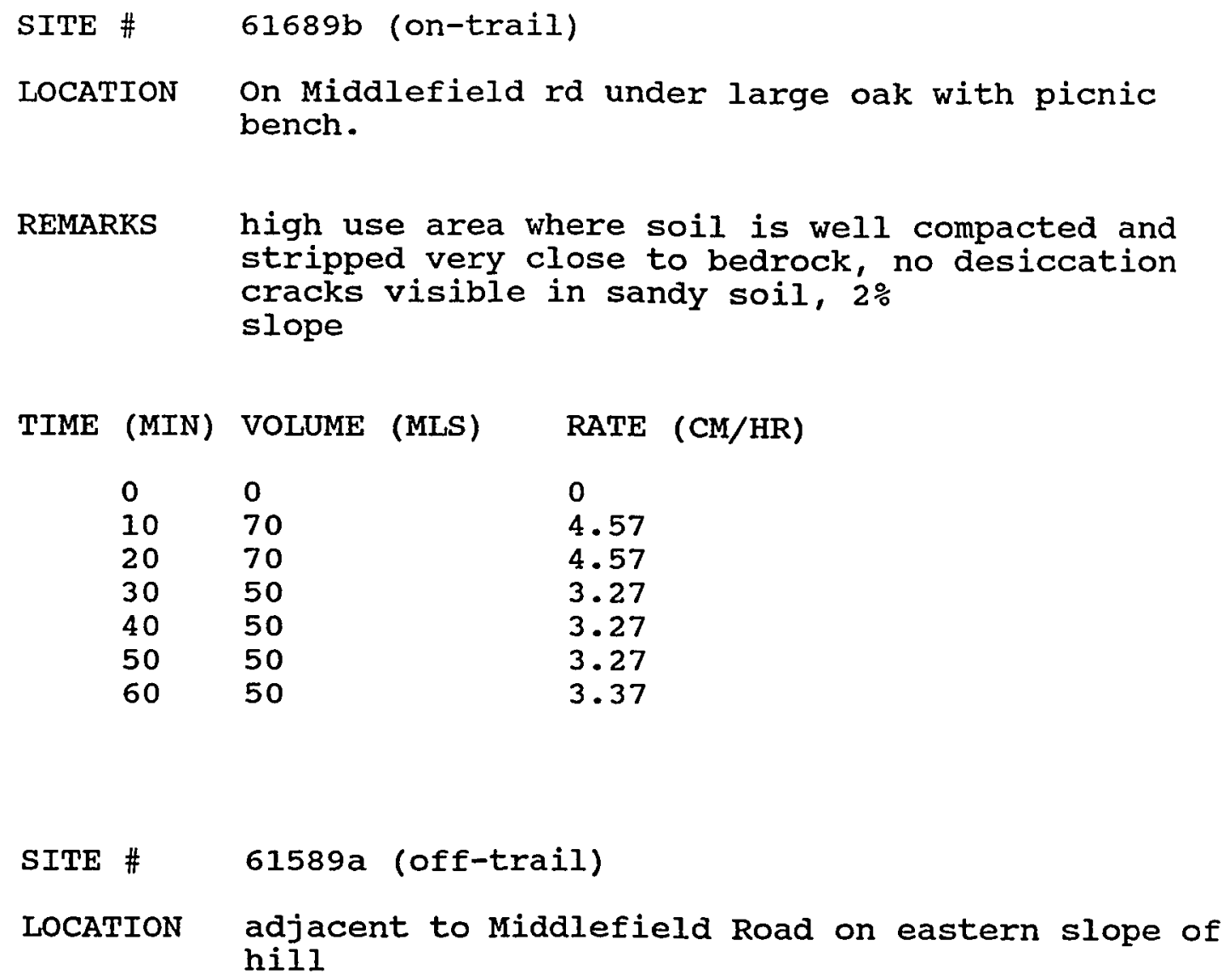

$\begin{array}{lll}0 & 0 & 0 \\ 10 & 70 & 4.57 \\ 20 & 70 & 4.57 \\ 30 & 50 & 3.27 \\ 40 & 50 & 3.27 \\ 50 & 50 & 3.27 \\ 60 & 50 & 3.37\end{array}$

SITE \# 61589a (off-trail)

LOCATION adjacent to Middlefield Road on eastern slope of hill

REMARKS ground is well vegetated with grasses, desiccation cracks visible.

TIME (MIN) VOLUME (MLS) RATE (CM/HR)

$\begin{array}{lll}0 & 0 & 0 \\ 10 & 340 & 22.3 \\ 20 & 330 & 21.5 \\ 30 & 260 & 17.0 \\ 40 & 170 & 11.1 \\ 50 & 230 & 15.0 \\ 60 & 200 & 13.0 \\ 70 & 200 & 13.0\end{array}$




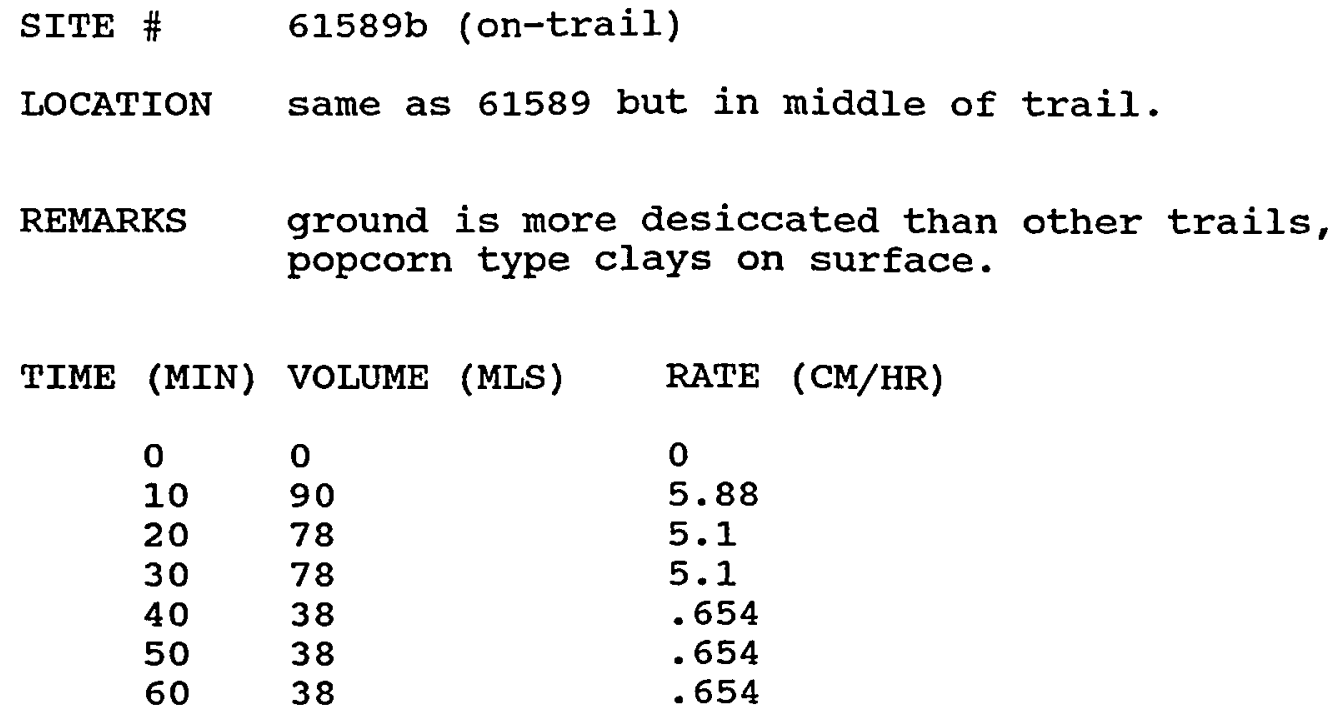

SITE \# 65902a (off-trail)

LOCATION on Backridge road approximately 30 yards before culvert.

REMARKS soft ground in the shade littered with dead organic matter from nearby tree, some vegetation present slope $=30 \%$

TIME (MIN) VOLUME (MLS) RATE (CM/HR)

$\begin{array}{lll}0 & 0 & 0 \\ 10 & 5400 & 353 \\ 20 & 2500 & 163.5 \\ 30 & 1300 & 85.0 \\ 40 & 1370 & 89.59 \\ 50 & 050 & 68.67 \\ 60 & 1050 & 68.67 \\ 70 & 1050 & 68.67\end{array}$




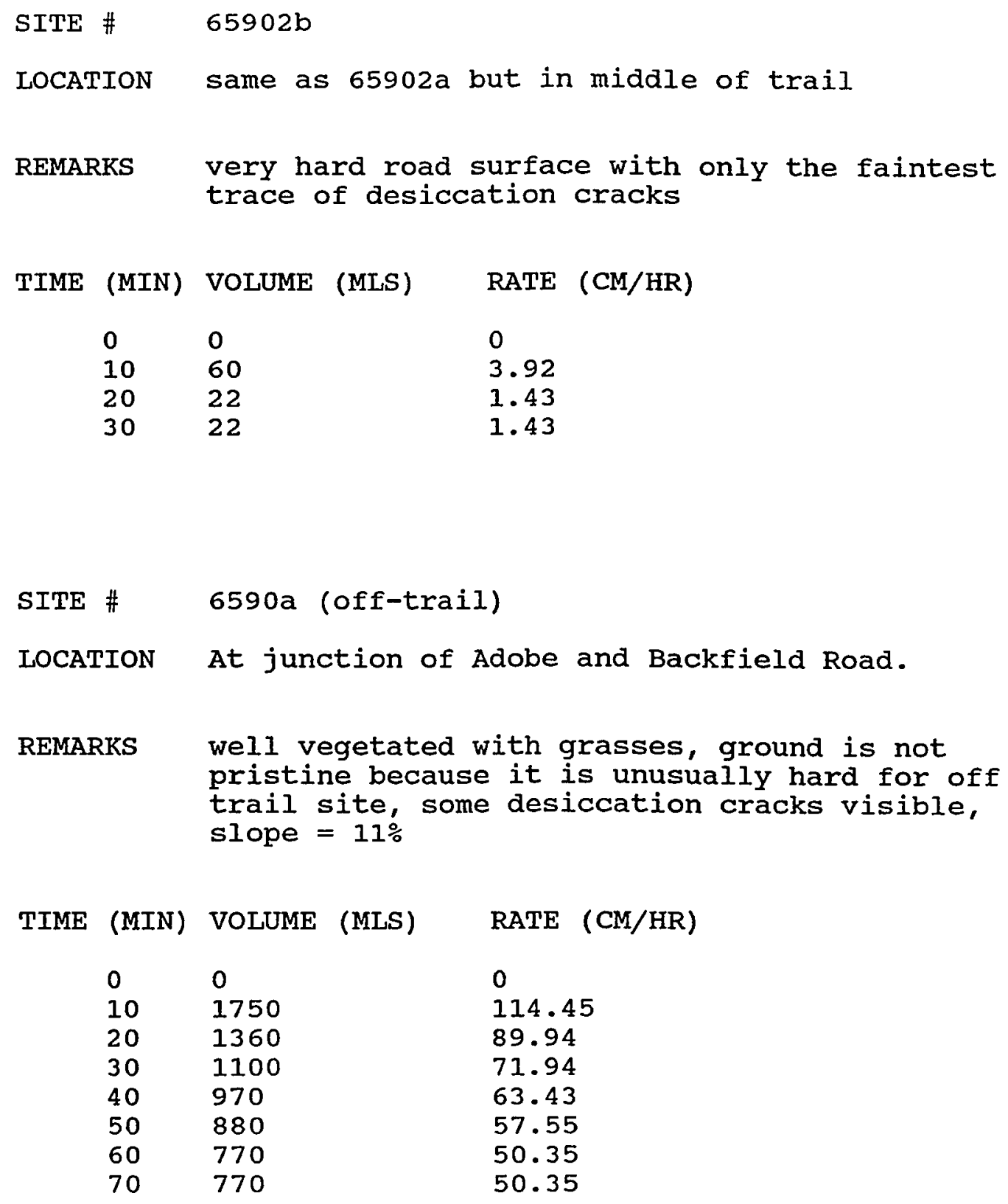


SITE \# $\quad 6590 \mathrm{~b}$ (on-trail)

LOCATION same as $6590 a$ but on trail

REMARKS high use area on a gentle slope. ground is desiccated and covered with popcorn type clays.

$\begin{array}{lll}\text { TIME (MIN) } & \text { VOLUME (MLS) } & \text { RATE } \\ 0 & 0 & 0 \\ 10 & 0 & 0 \\ 20 & 0 & 0 \\ 30 & 0 & 0 \\ 40 & 0 & 0 \\ 50 & 18 & 1.17 \\ 60 & 0 & 0 \\ 70 & 0 & 0\end{array}$


APPENDIX B- INFILTRATION DATA

Data obtained from the double ring infiltrometer test was analyzed using "grapher" a computer graphics package and presented as arithmetic plots representative of the infiltrometer rates vs. elapsed time. Each graph represents and individual test.

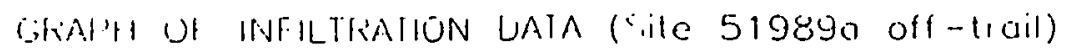

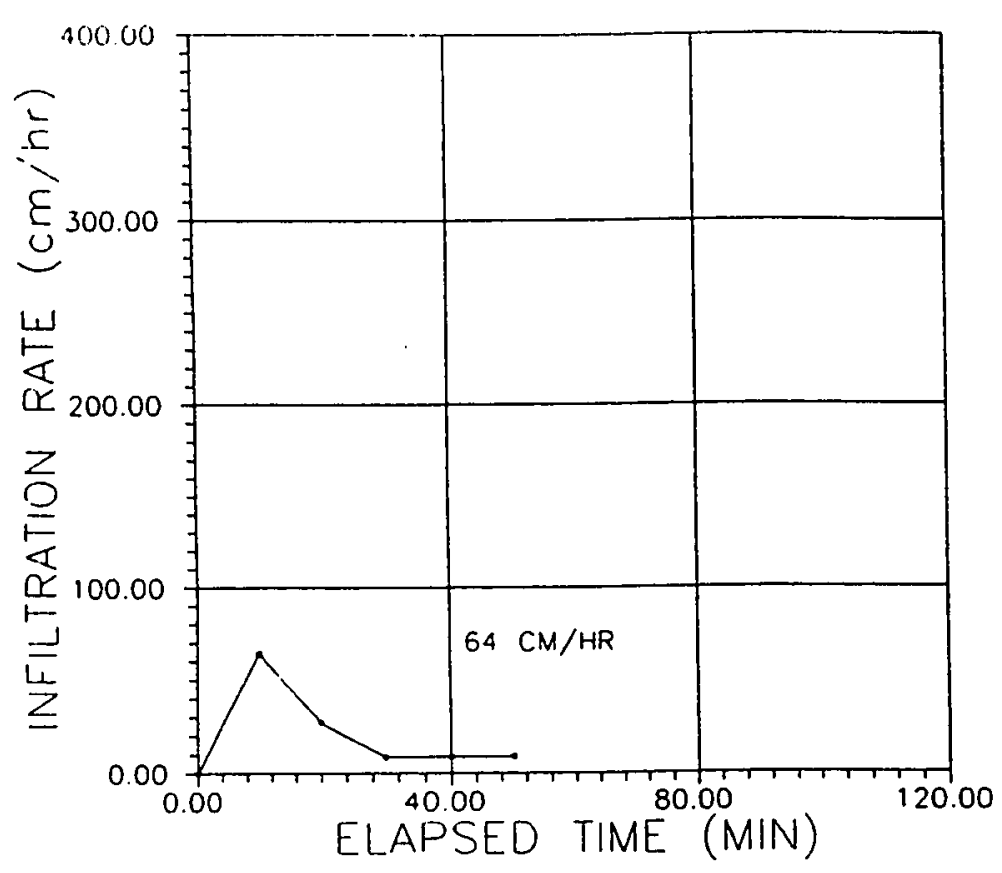


GRAPH OF INFILTRATION DATA ('Sile $51989 \mathrm{~b}$ on-trail)

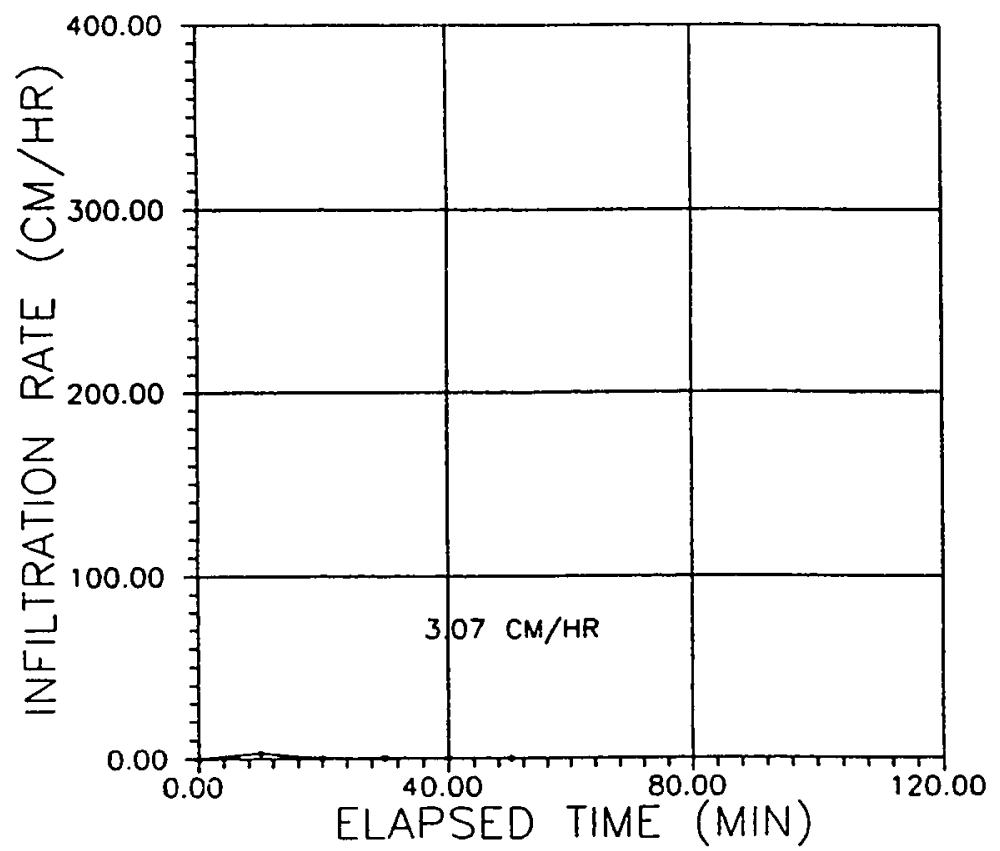


GKAIII UF INFILTRAIION DAIA (Sile 11290 OIf-.l (uil)

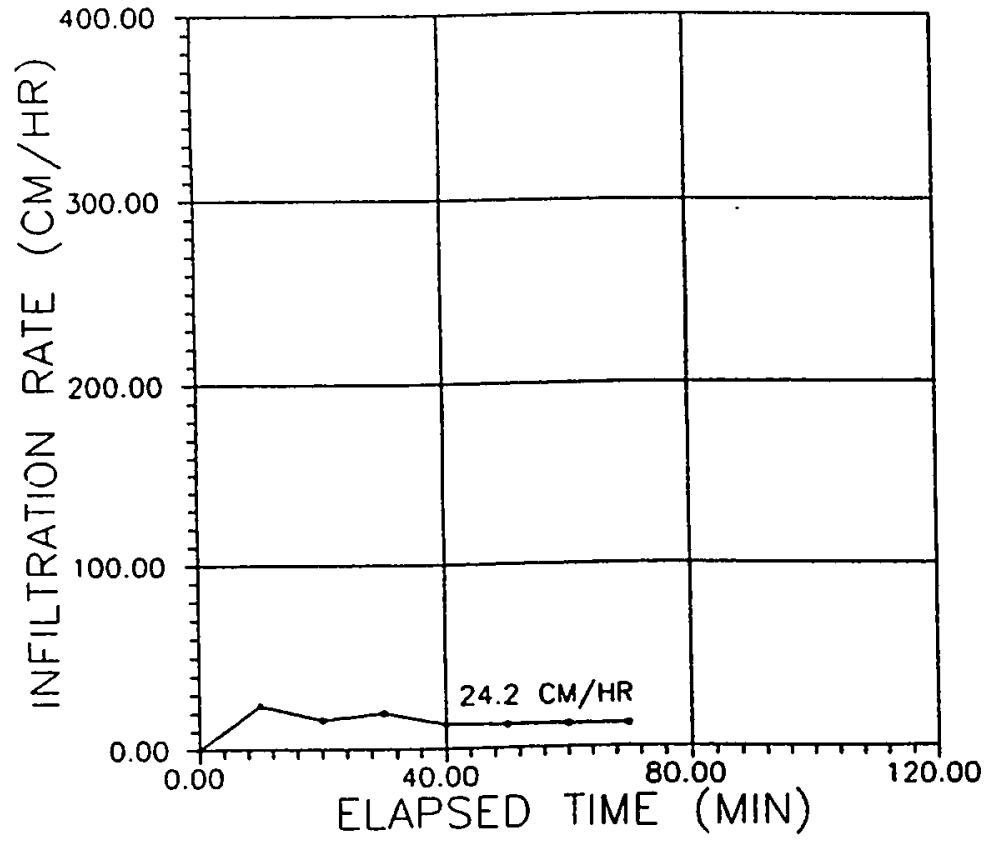


GRAPH OF INFILTRATION DATA (Site 61589 on-trail)

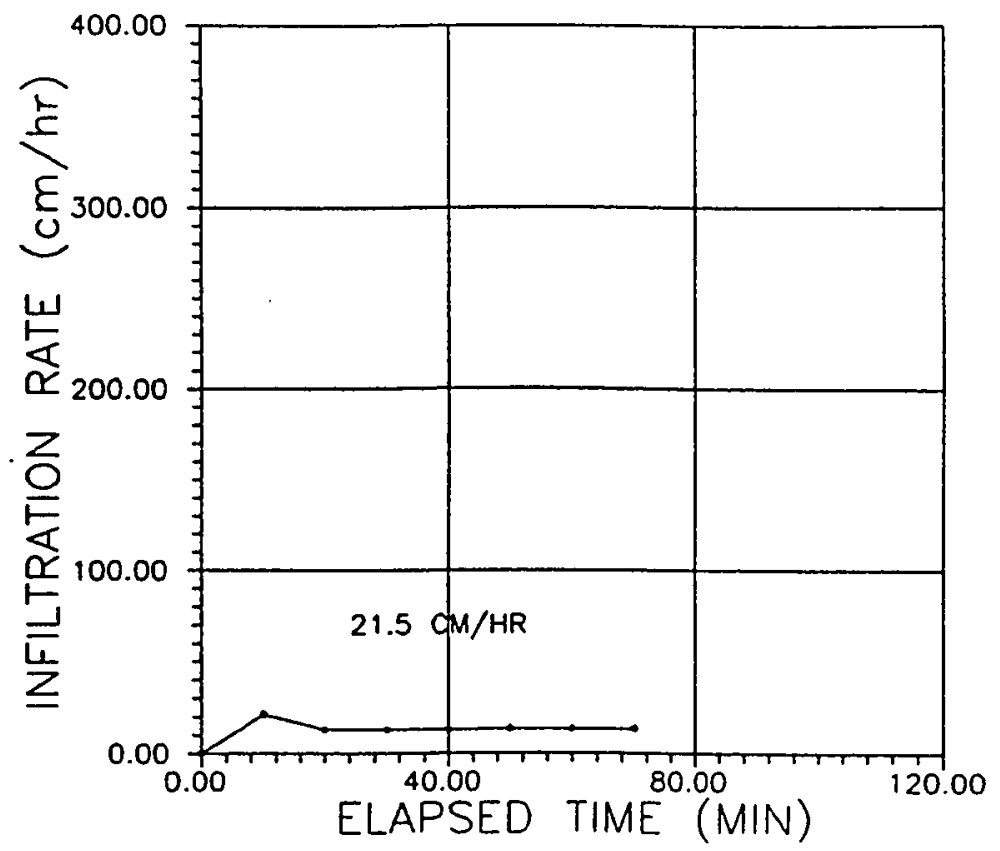


GRAPH OF INFILTRATION DATA (Site 111902o off-trail

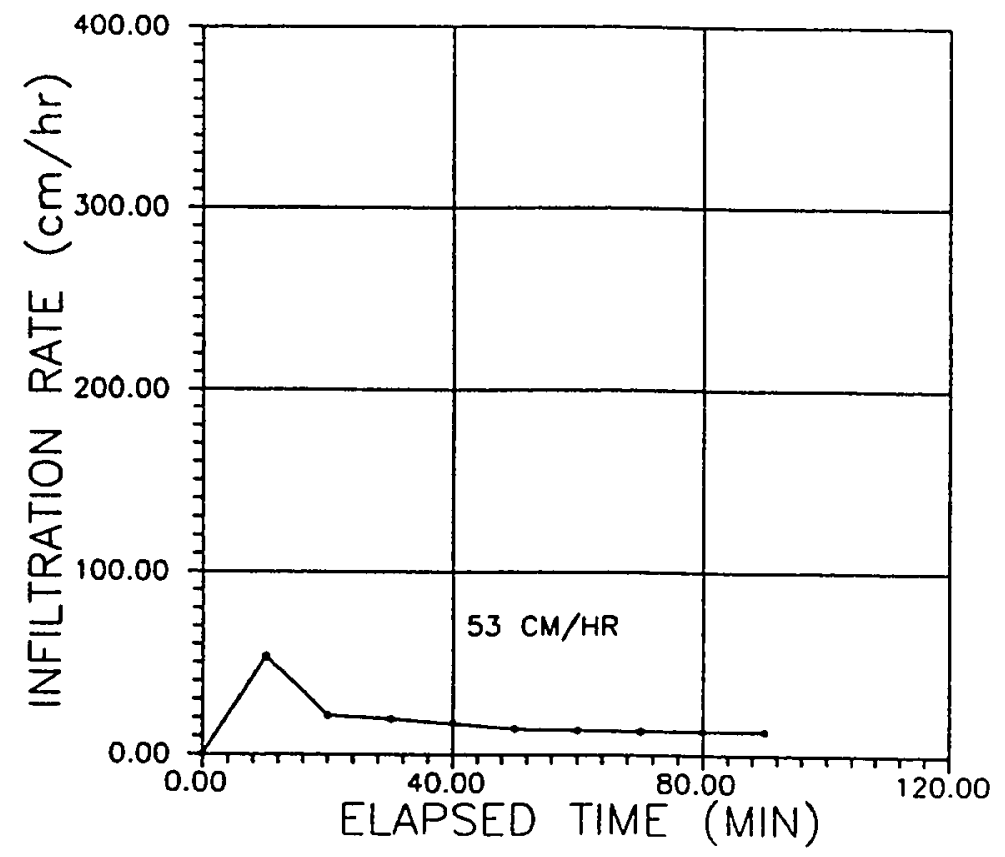


1.1FAPH OF INFILTRATION DATA (Site $51989 \mathrm{~b}$ on-trail)

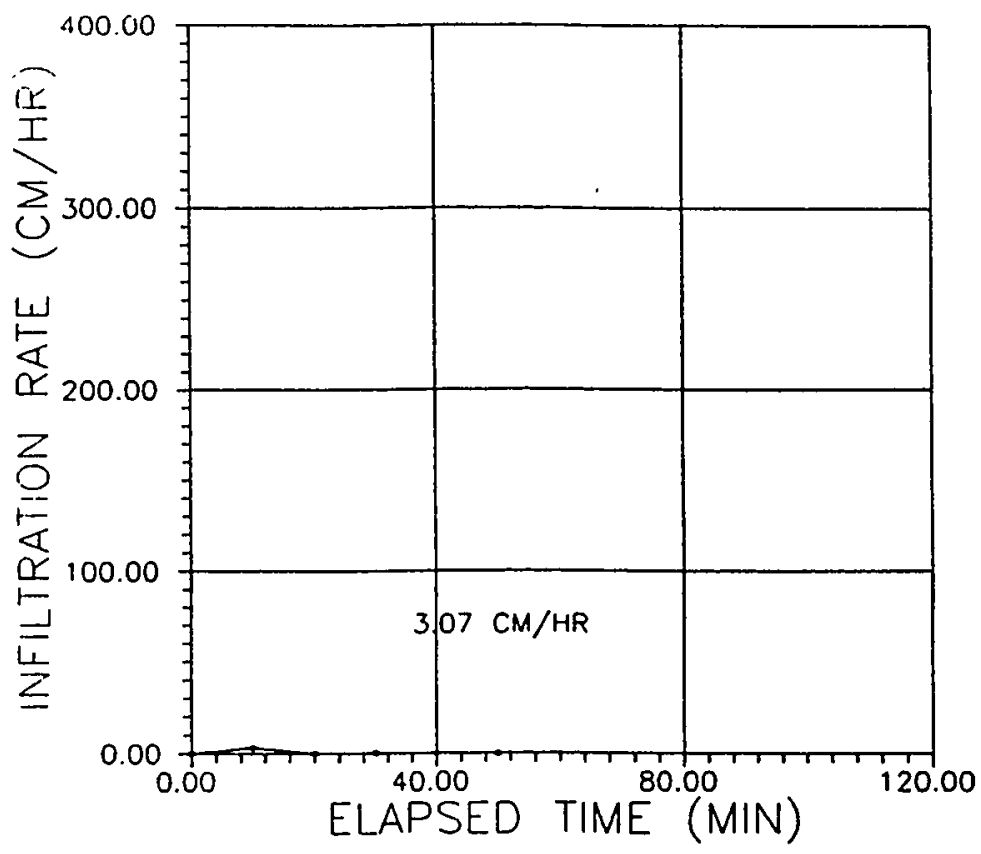


101

GRAPH OF INFILTRATION DATA (Site 11290 off-trail)

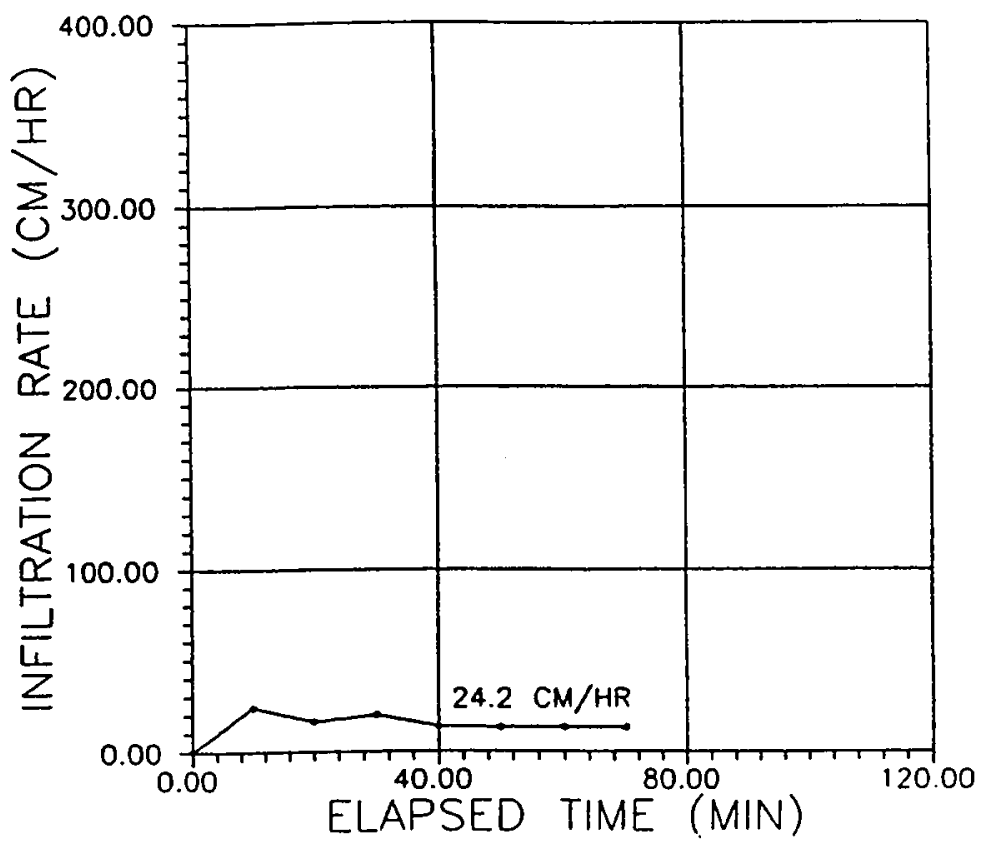


SRAFH UF INFILTRATION DATA (Site $61589 \mathrm{~b}$ on-trail)

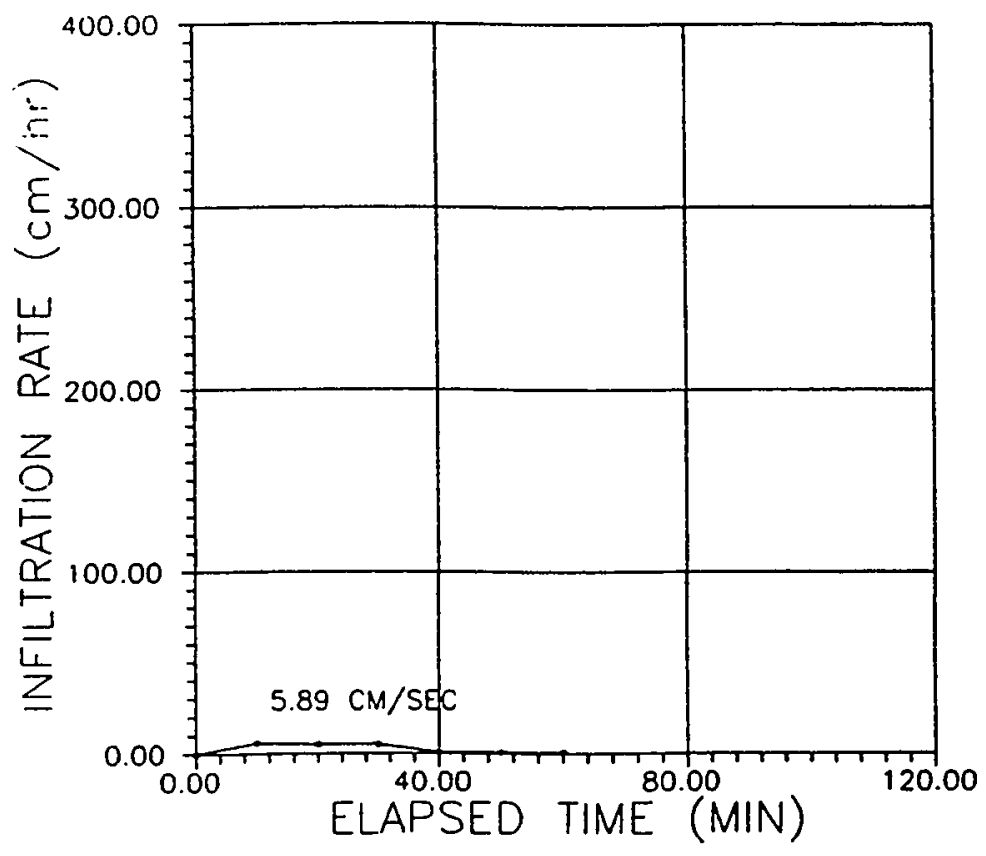


CRAPH OF INFILTRATION DATA (Site111902a off-trail)

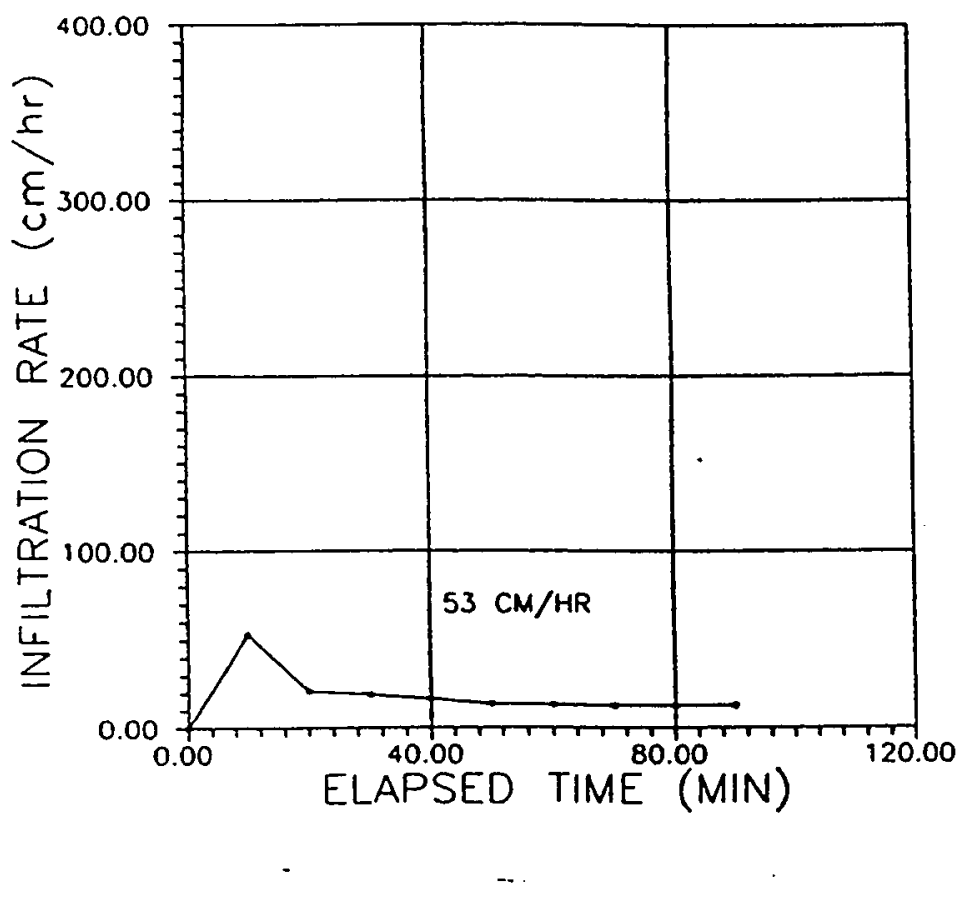


GRAIH OF INFILTRAIION DATA (SITE $111902 \mathrm{~b}$ On--trail)

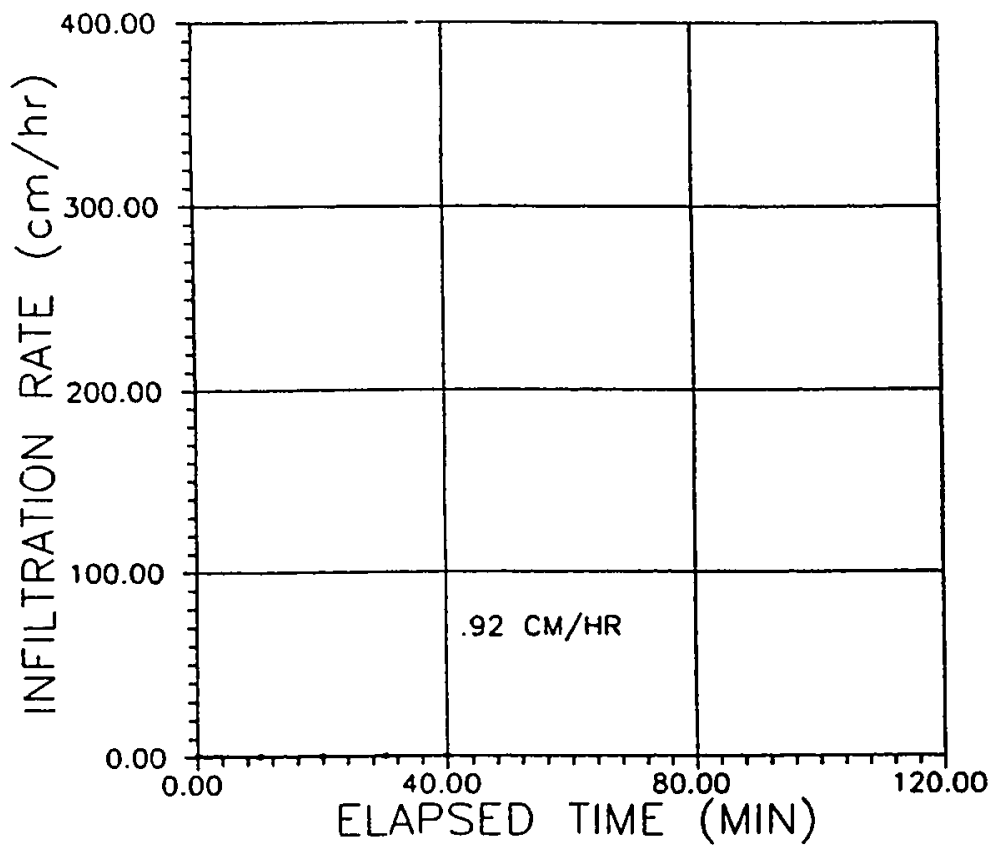


GRAPH OF INFILTRATION (Site 64902a off-trail)

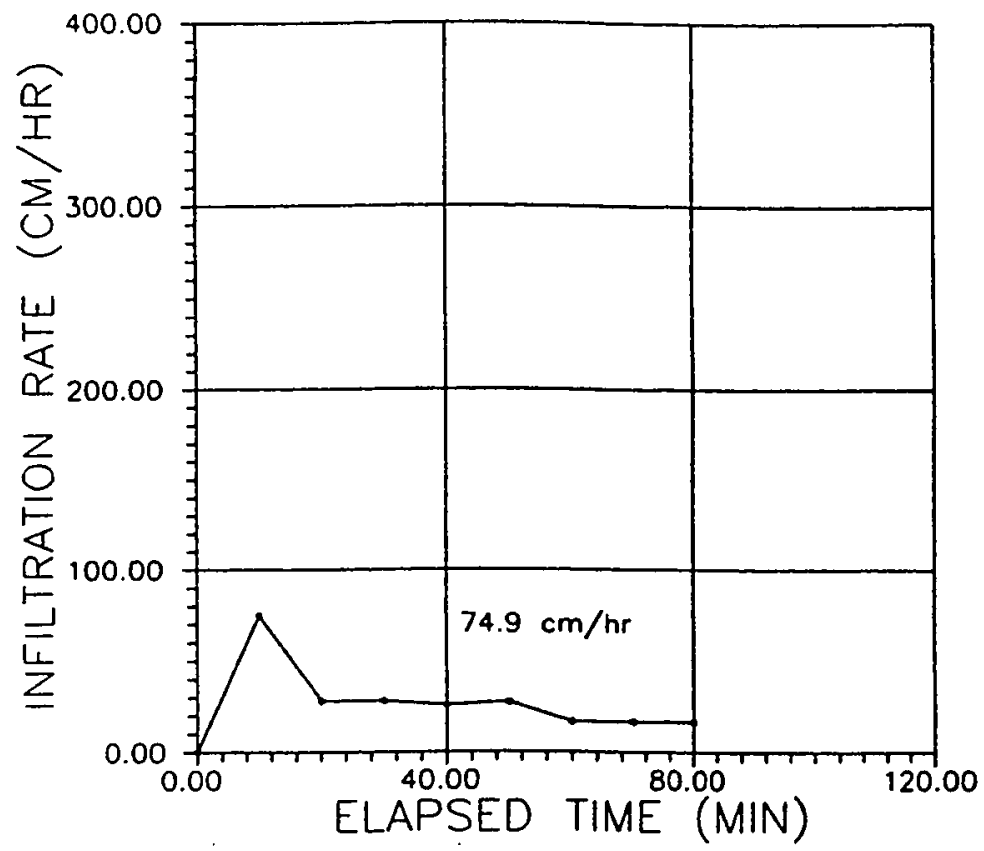


GRAPH OF INFILTRATION (Site 64902b on-troil)

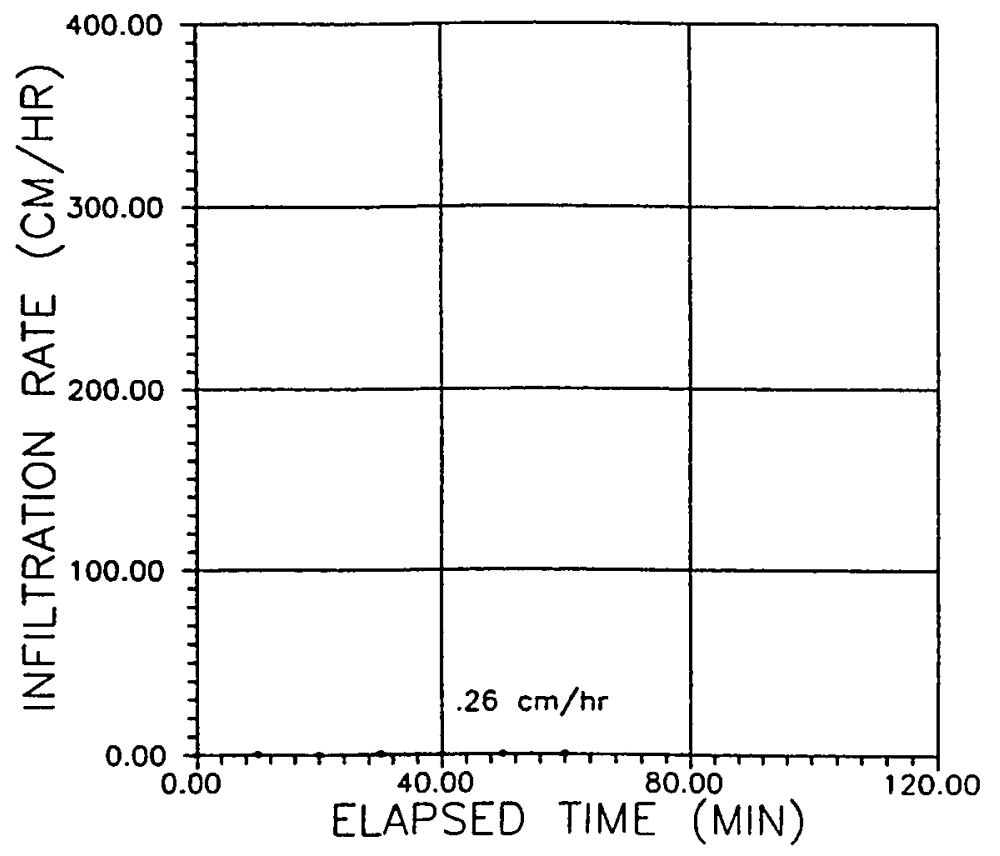


GRAPH OF INFILTRATION (Site 6490a off-trail)

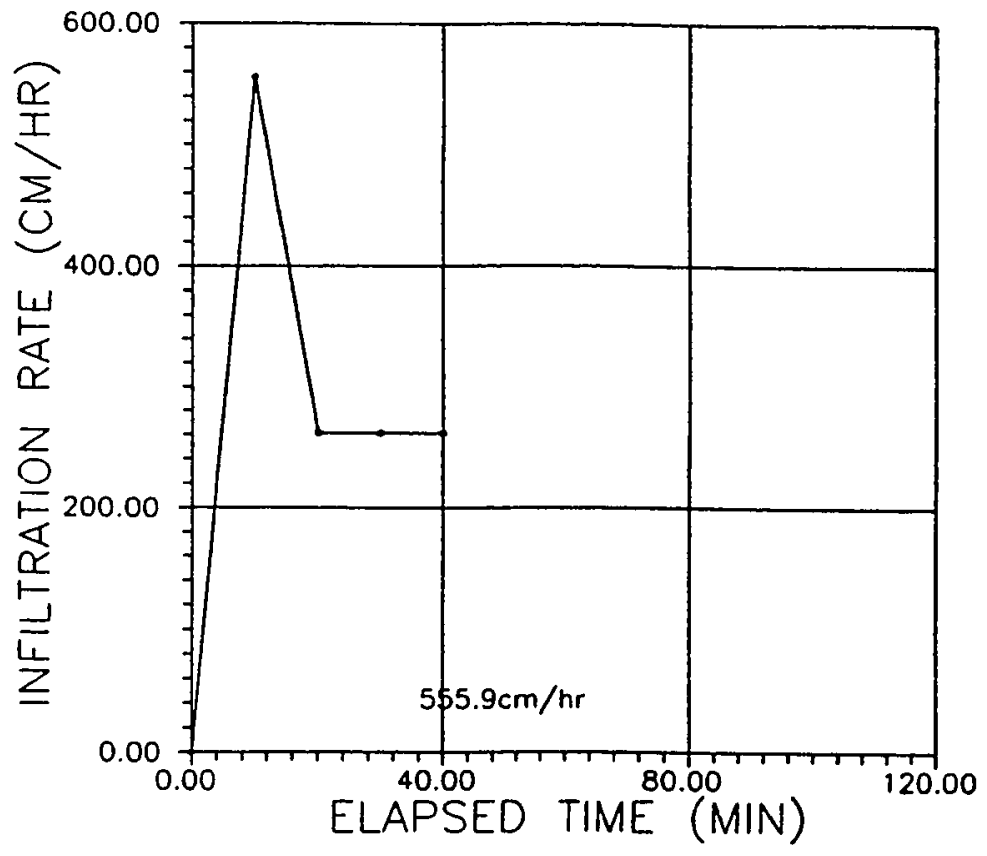


GRAPH OF INFILTRATION (Site 6490b on-trail)

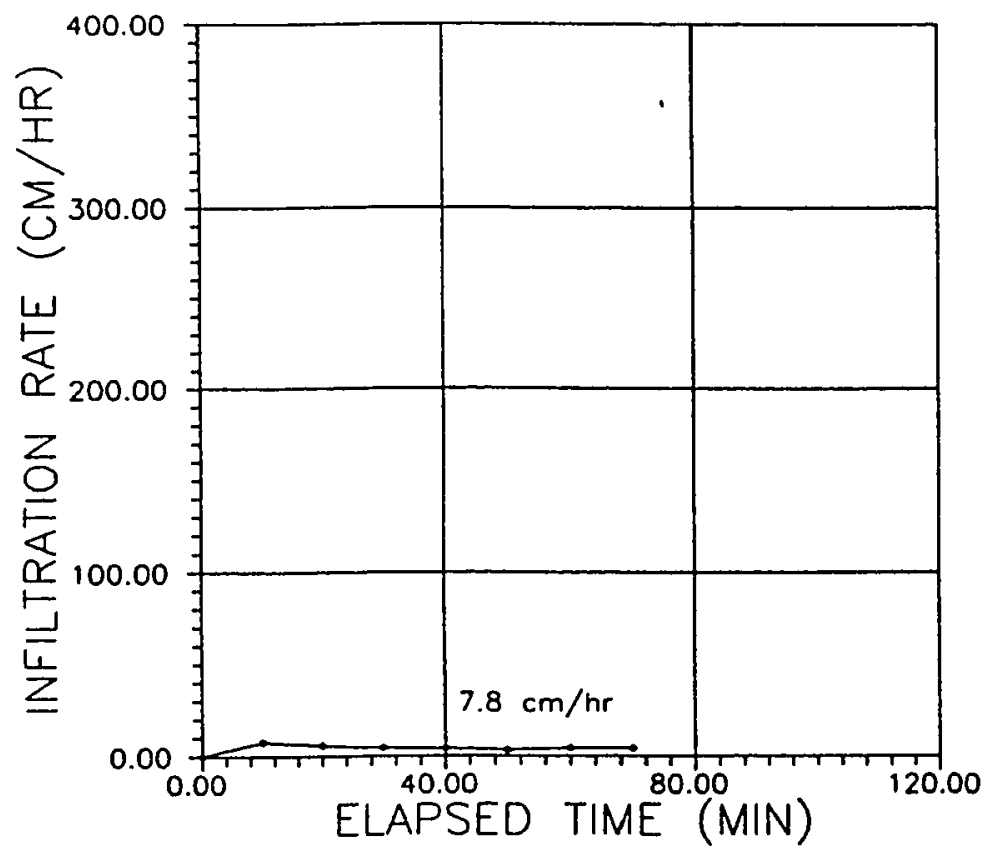


CRAPH OF INFILTRATION DATA (Site 111900 off-trail)

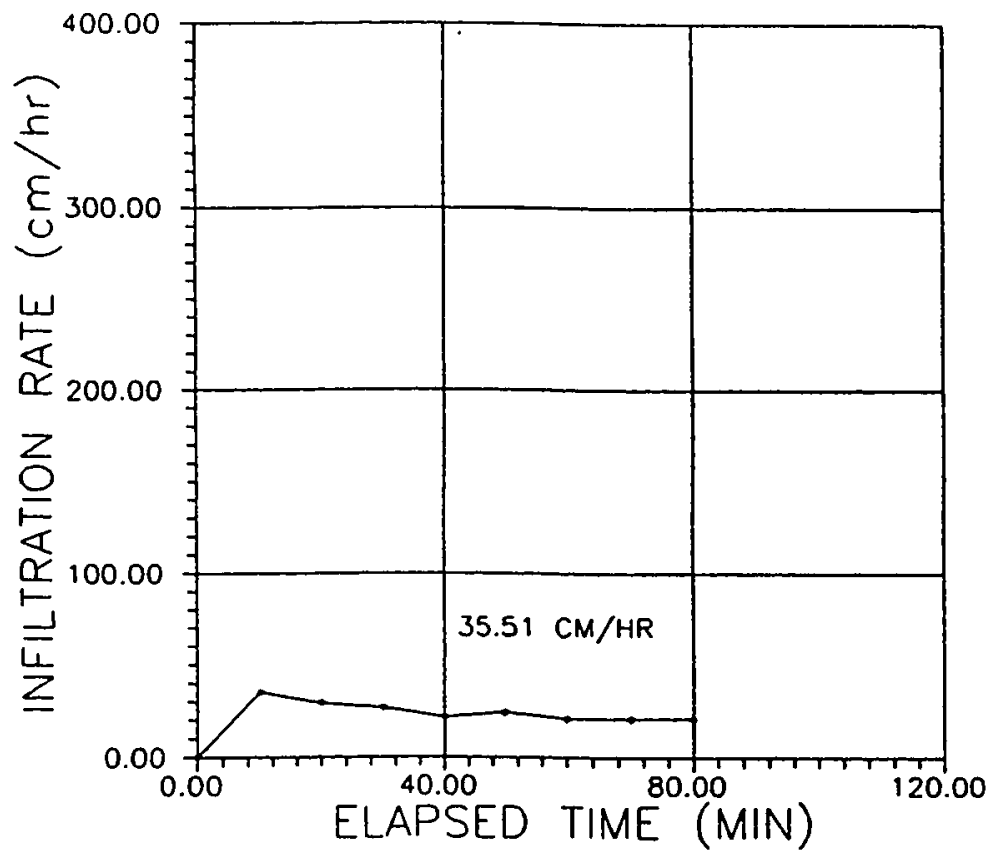




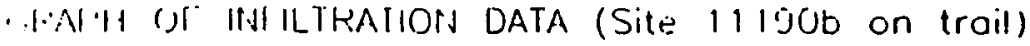

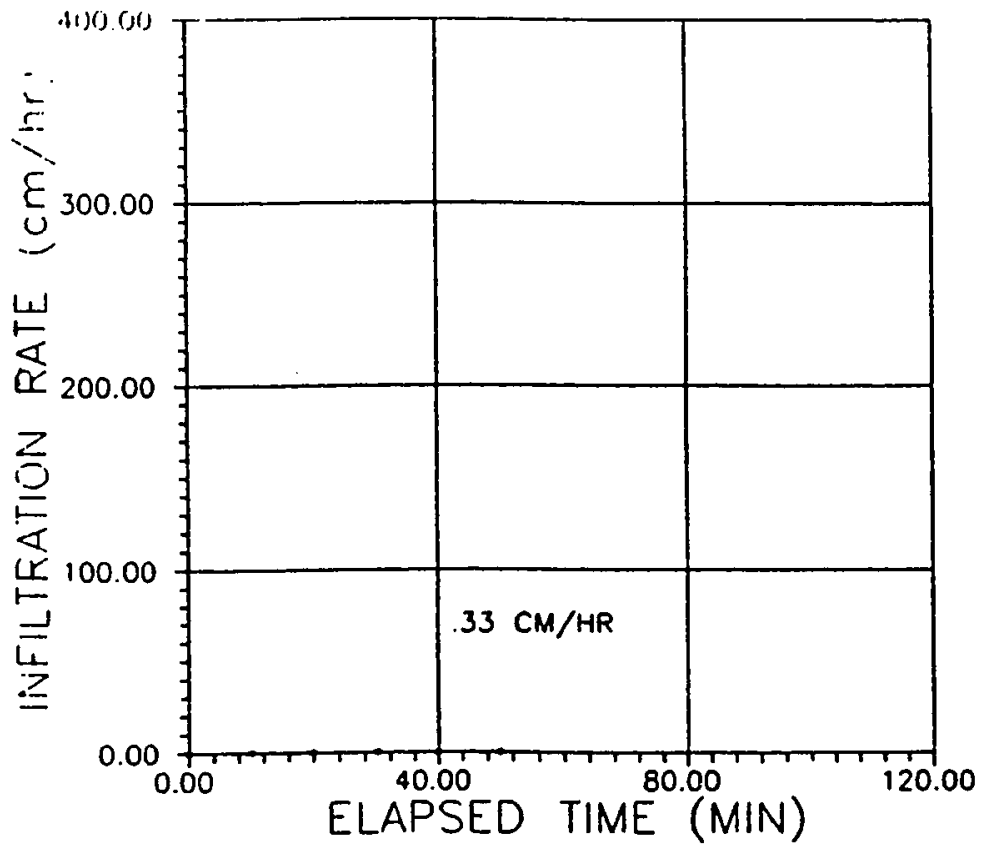

$\therefore$ 


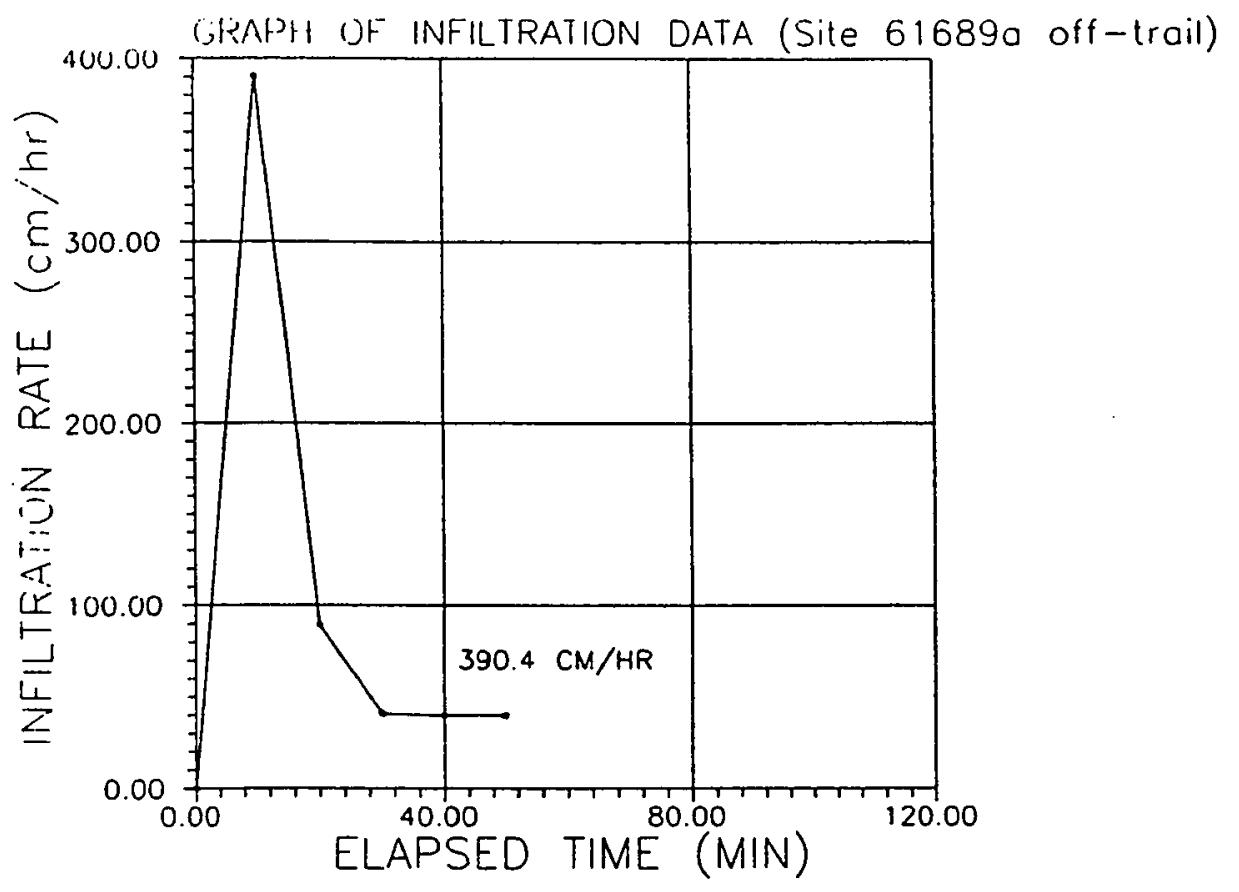


GRAPH OF INFILTRATION DATA (Site 61689bon-trail)

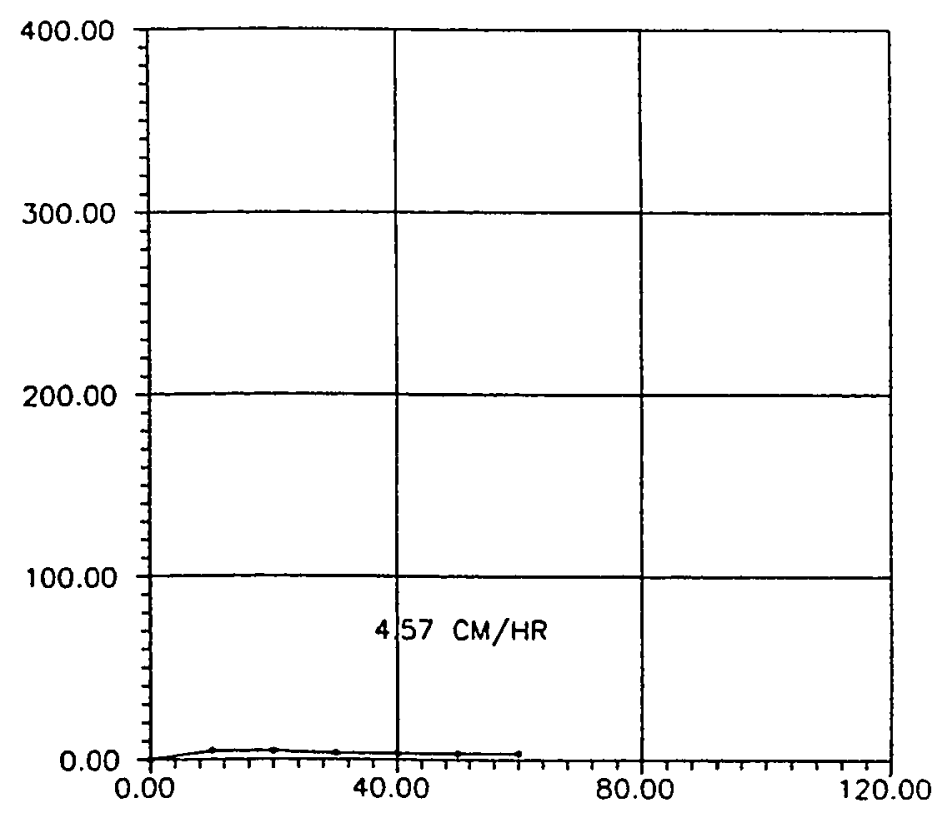




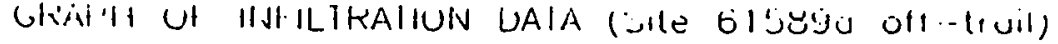

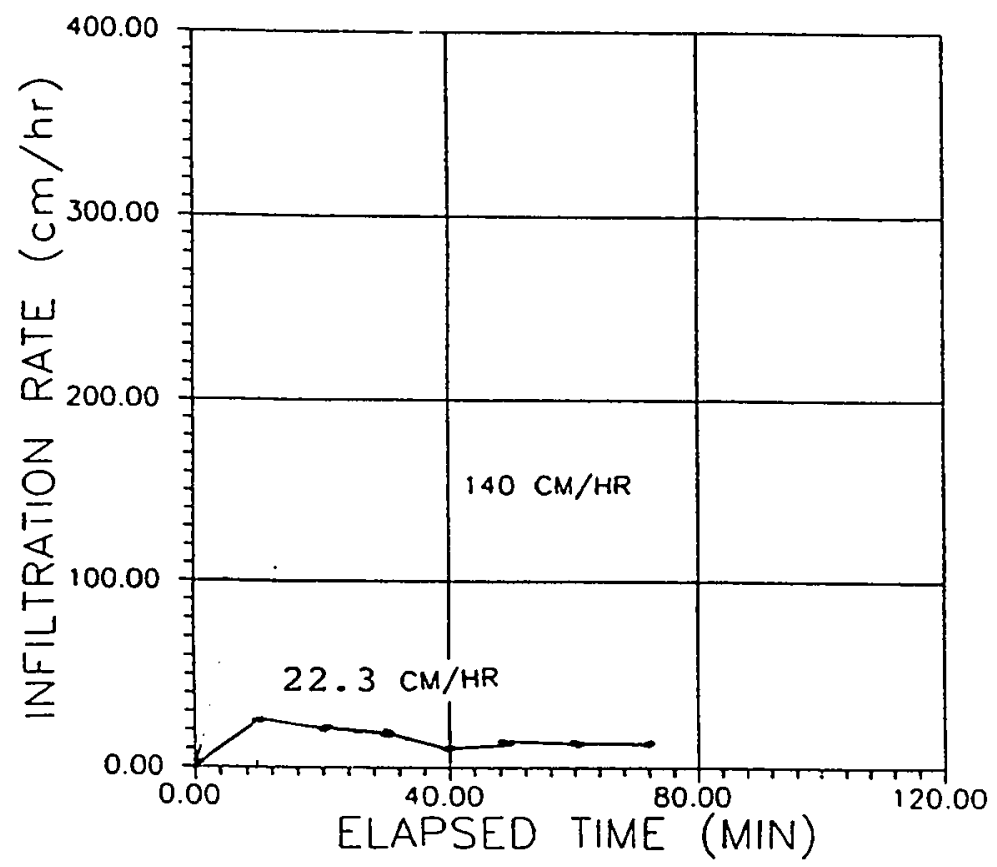


GKÁPl OF: IINH ILIRATION DATA (Site 61589b on-trail)

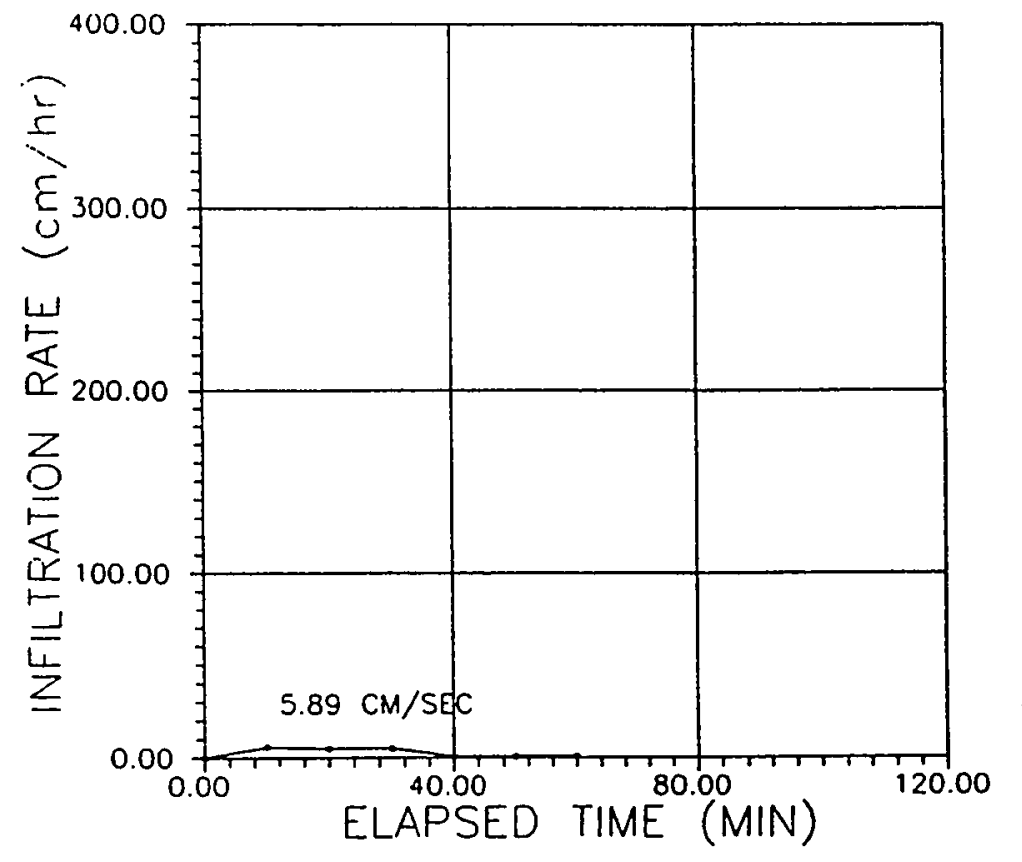


(GIAAHI I)I INIIILTRATION (Site 659020 off-troil)

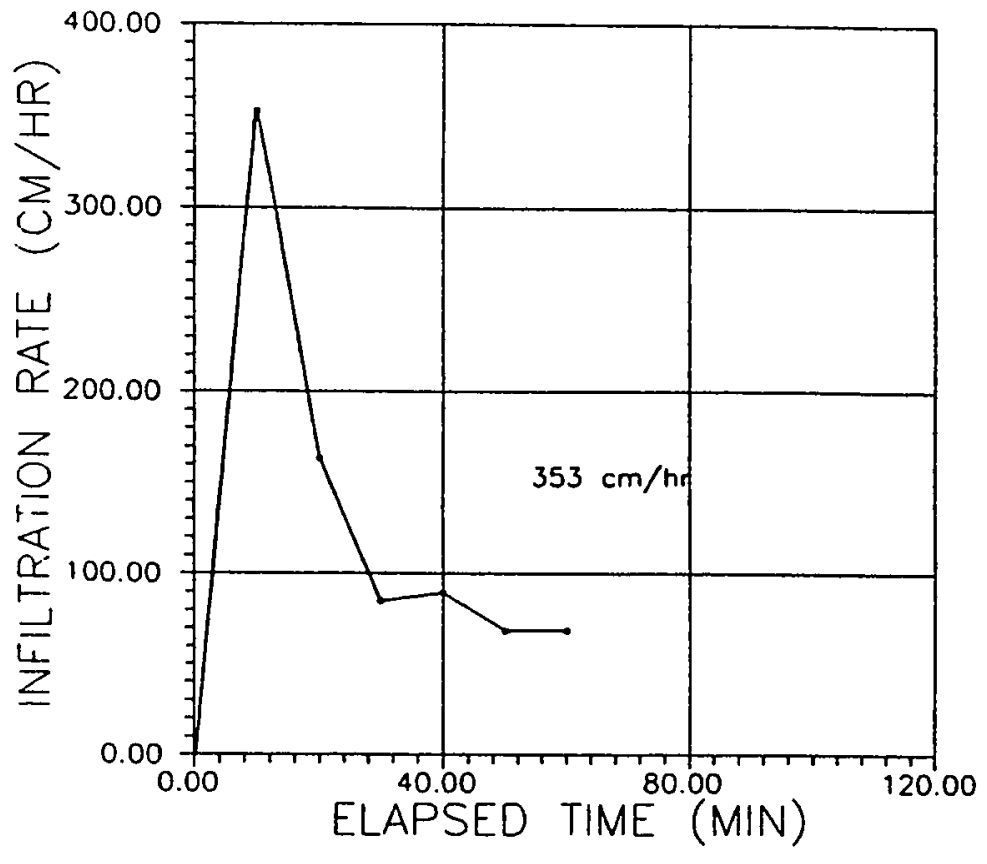




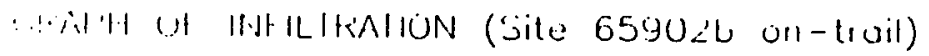

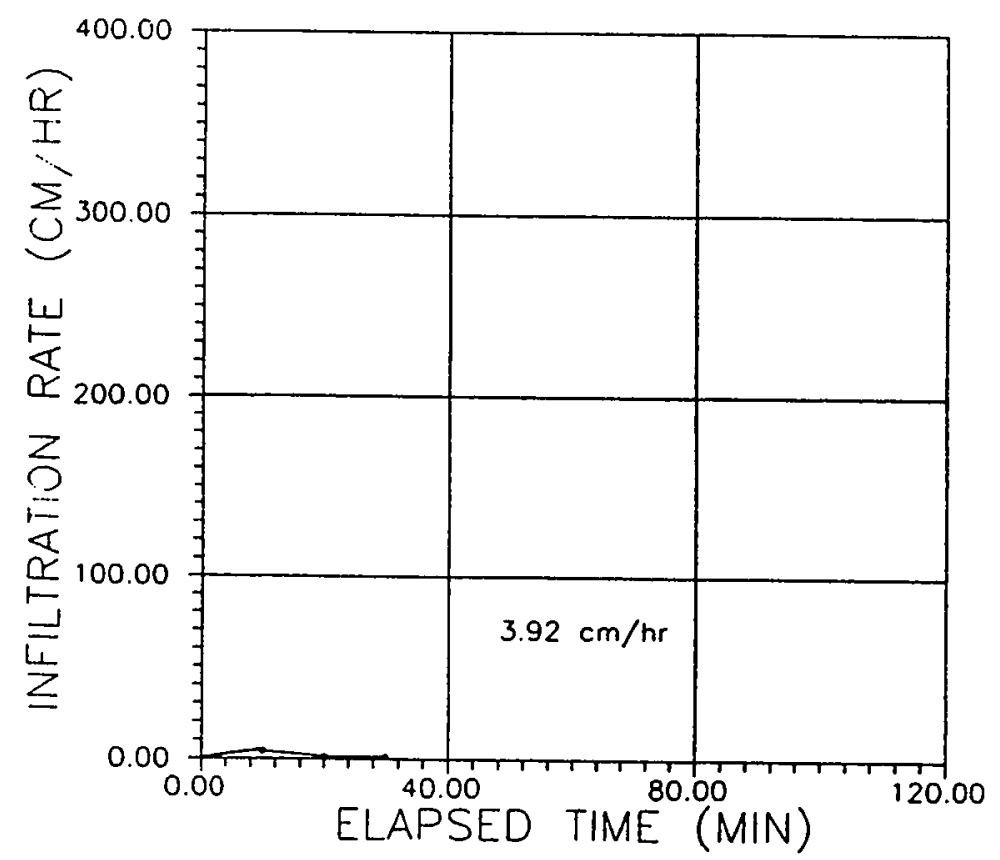


GKAFHI (I INFILIRATION (Site 55900 off-trail)

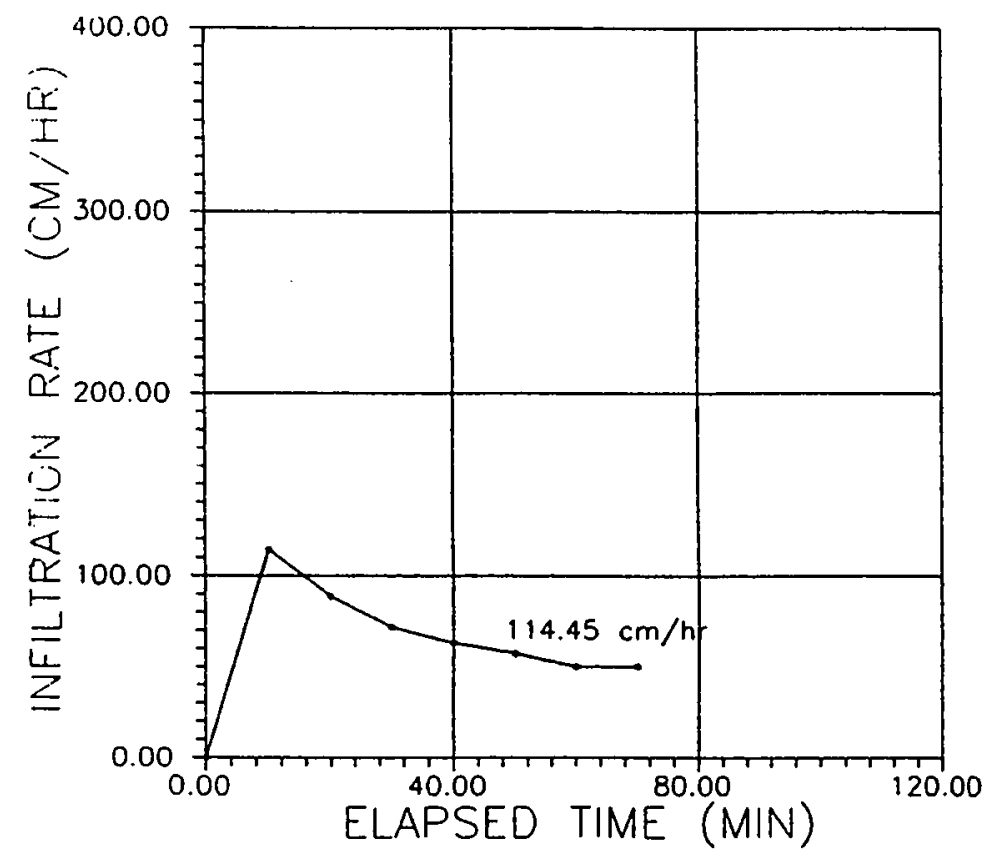


1.WAH OH INFILIRAIIUN (Site 6590b on-troil)

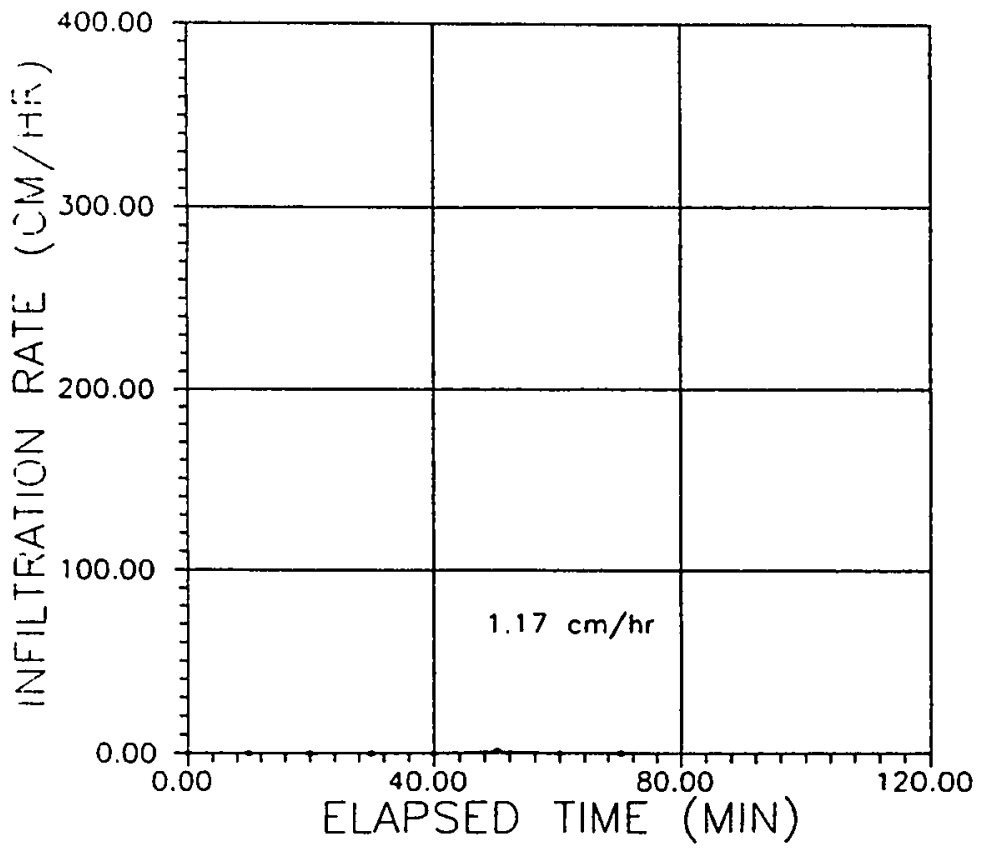




\section{PLEASE NOTE:}

Oversize maps and charts are filmed in sections in the following manner:

\section{LEFT TO RIGHT, TOP TO BOTTOM, WITH SMALL OVERLAPS}

The following map or chart has been refilmed in its entirety at the end of this dissertation (not available on microfiche). A xerographic reproduction has been provided for paper copies and is inserted into the inside of the back cover.

Black and white photographic prints $\left(17^{\prime \prime} \times 23^{\prime \prime}\right)$ are available for an additional charge.

\section{University Microfilms International}


- 


\section{EXPLANATION}

\section{LANOSLHEES}

\section{SLUMP/EARTHFLOW}

0

AVERAGE SIZE $=9$ ACRES RECOGNIZED BY A CONCAVE AMPHI WITH TENSION AND DESSICATION CRACKS IN THE SOIL ABOVE THE INACTIVE FEATURES ARE MORE SUBTLE AND ARE WELL VEGETATE

\section{SLUMPS}

AVERAGE SIZE $=.68$ ACRES. THE INTERIOR OF THE SLIDE DISPLA' BLOCKS THAT ARE HORIZONTAL OR DIPPING BACK INTO THE HILLSL SEVERAL OCCUR AT THE BASE OF LARGE SLUMP/EARTHFLOWS.

DEBRIS SLIDE/ÂVALÂNCHE

A AVERAGE SIZE $=1.7$ ACRES . SLIDES HAVE A HIGH LENGTH TO WII RATIO AND TYPICALLY OCCUR ON SLOPES OF 16 TO 30 DEGREES MOST ARE CONFINEDTO PRE-EXISTING DRAINAGES .

ROCKFALL

R A CHAOTIC MASS OF DEBRIS AT THE BASE OF NEARLY VERTICAL SCARPS,MOST OCCUR AT OVER STEEPENED ROAD CUTS. 
ONCAVE AMPHITHEATER SHAPE SOIL ABOVE THE CROWN. NELL VEGETATED

¿ SLIDE DISPLAYS STEPPED VTO THE HILLSLOPE . ARTHFLOWS.

LENGTH TO WIDTH O 30 DEGREES .

ILY VERT!CAL UTS.

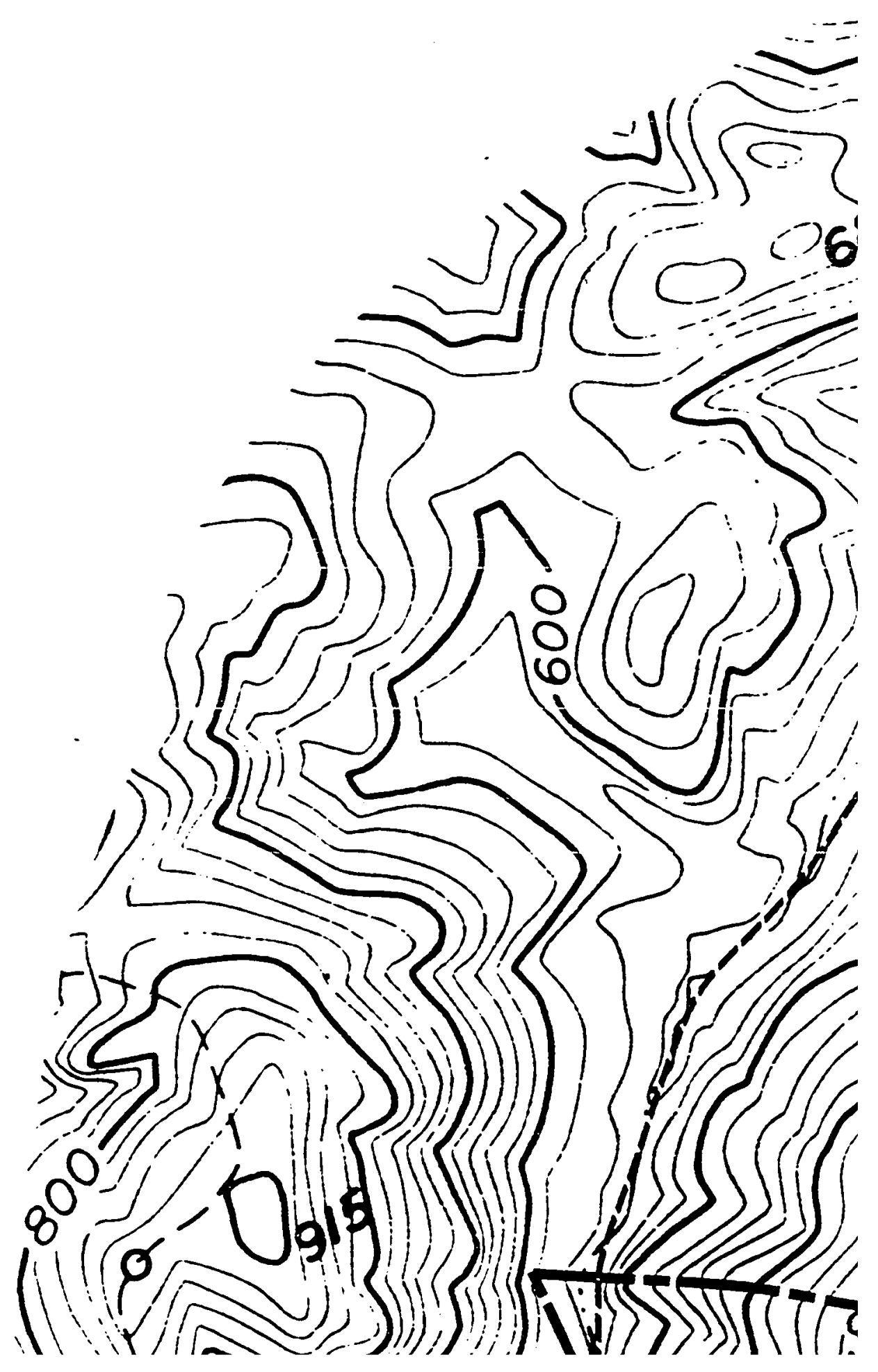





\section{EROSIONAL LAND-FORM MAP OF THE R|}

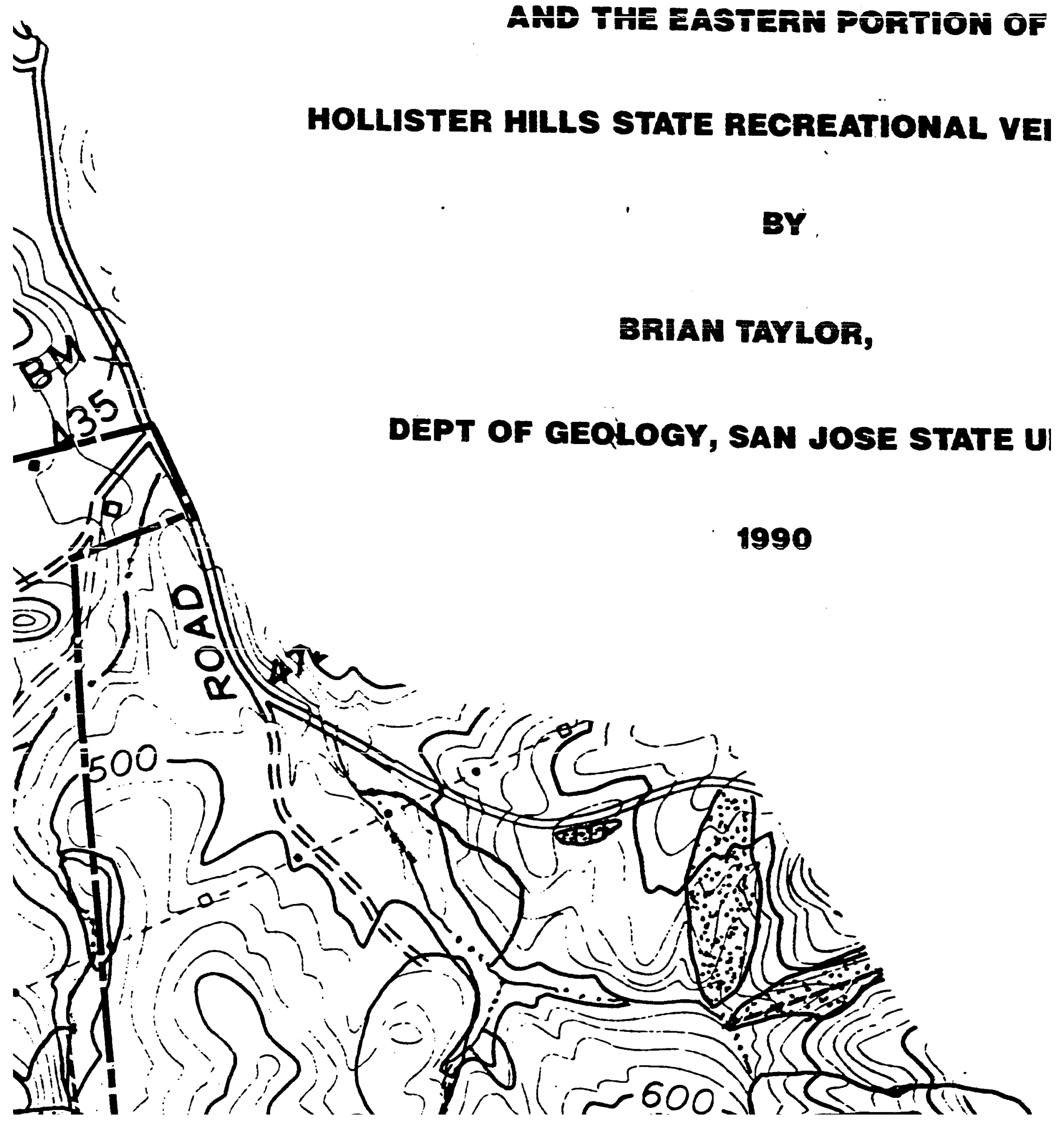




\section{LAND-FORM MAP OF THE RENZ ACQUISITION}

, THE EASTERN PORTION OF

LS STATE RECREATIONAL VEHICULAR AREA

BY

BRIAN TAYLOR,

MEQLOGY, SAN JOSE STATE UNIVERSITY

1990

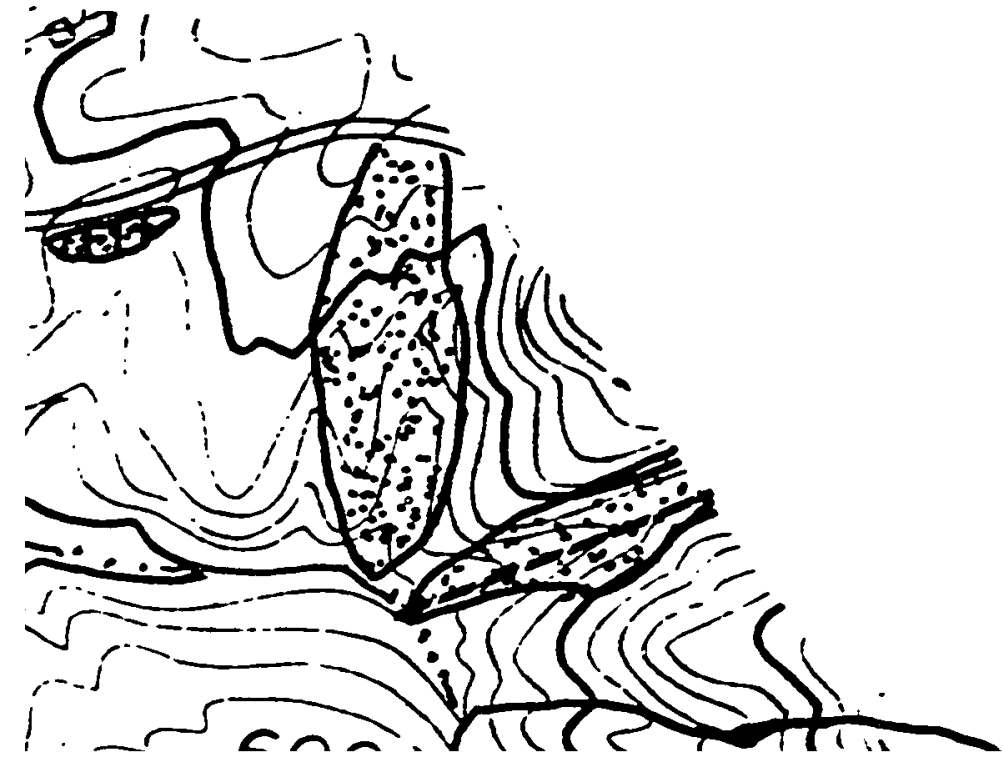


R a ChaOtIC MASS OF DEBRIS AT the base OF NEARLY VERTICAL SCARPS,MOST OCCUR AT OVER STEEPENED ROAD CUTS.

\section{ACTIVE LANDSLIDES}

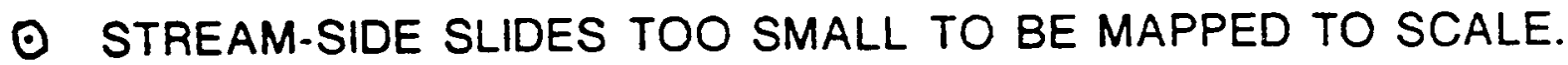

\section{FIUYIAL EROSION}

\section{PIPING}

INDICATED BY STRAIGHT CHANNELS THAT ROUGHLY PARALLEL TH
a CIRCULAR OPENING MAY BE PRESENT AT THE UPSLOPE END. THI ARE A RESULT OF SUBSURFACE EROSION.

\section{GULLIES}


IERTICAL

¿ETATED SCARPS

:D VEGETATION.

:CENT MOVEMENT.

CALE.

'ARALLEL THE SLOPE FACE. OPE END THESE FEATURES

CHANNELS.

IAJOR DRAINAGES IN THE

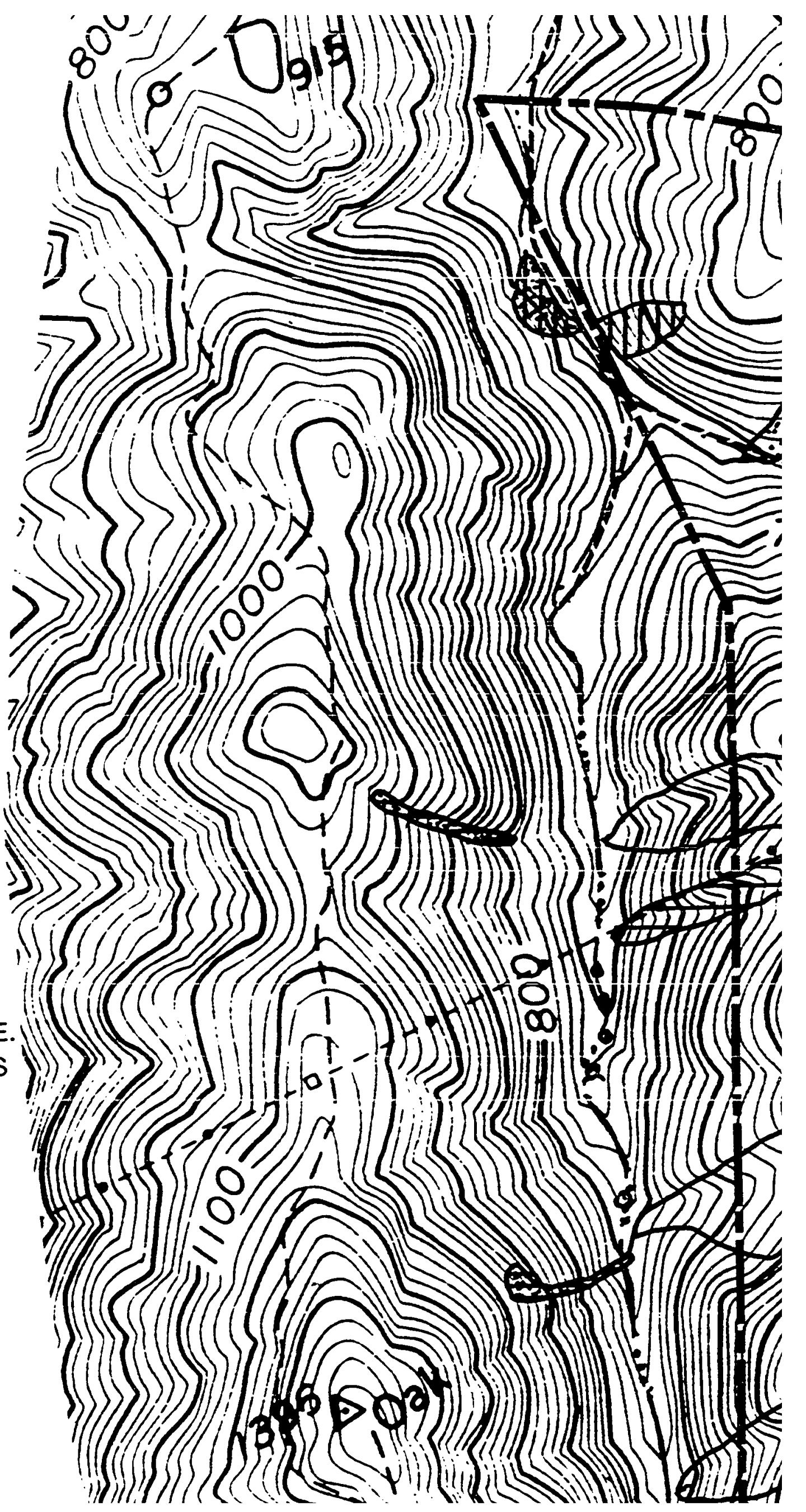





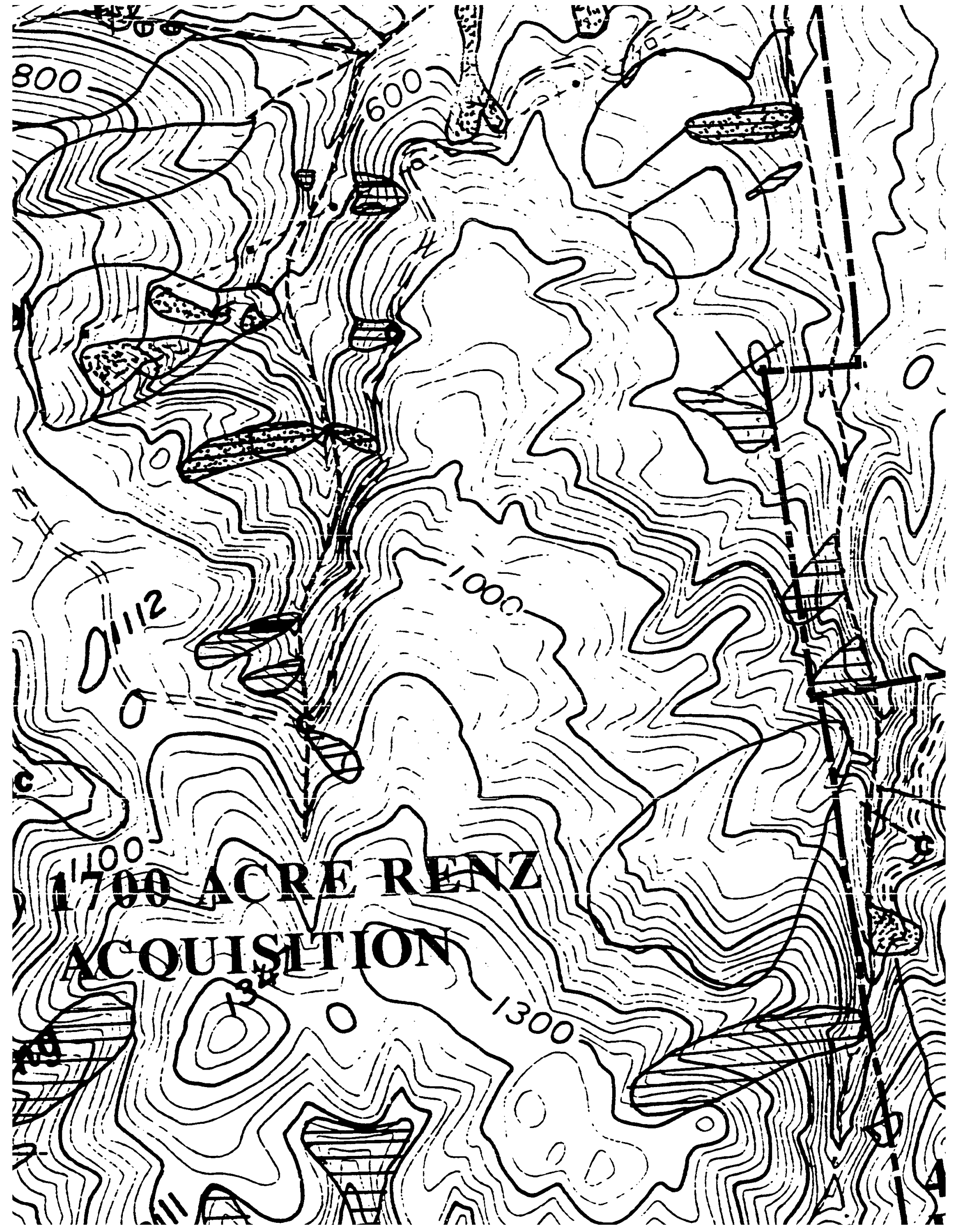




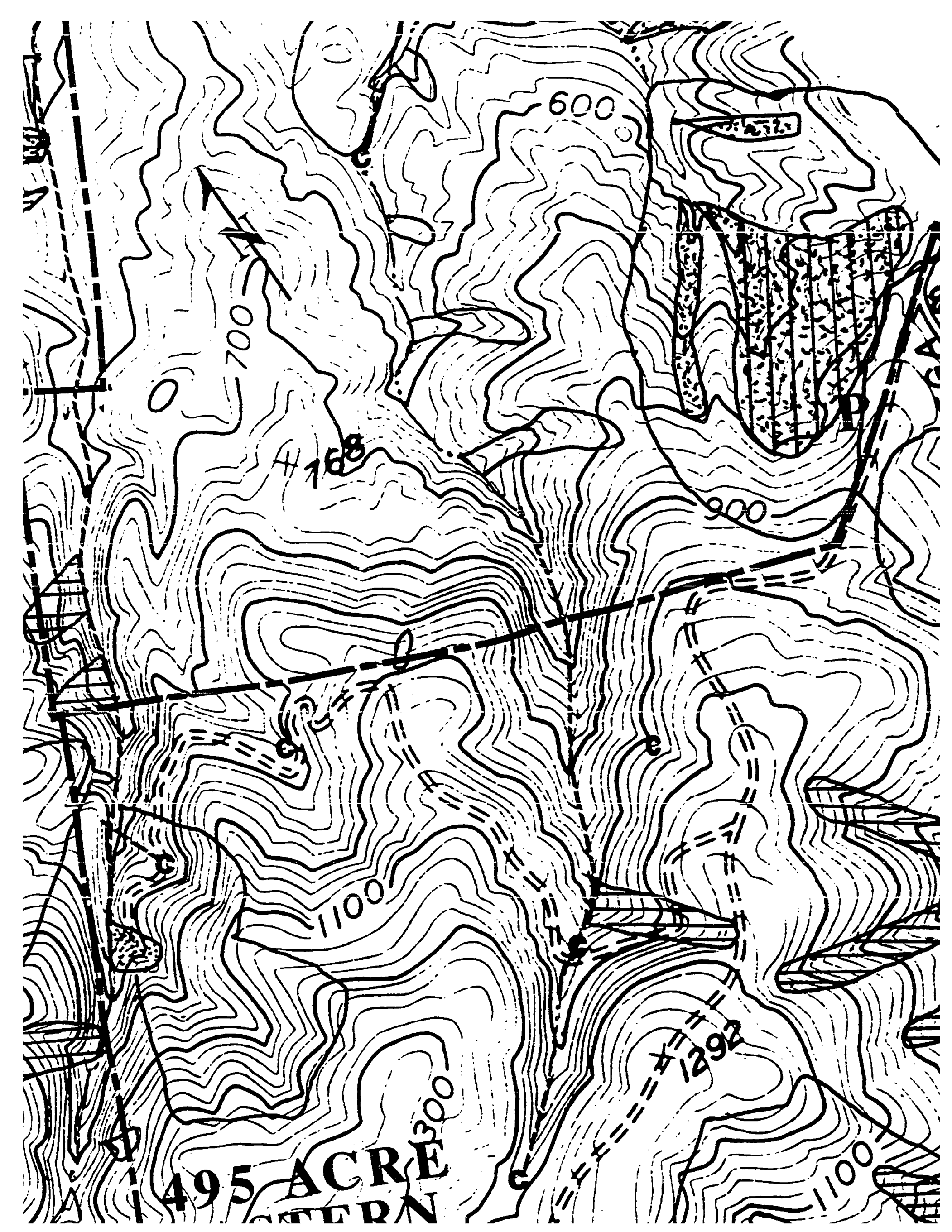




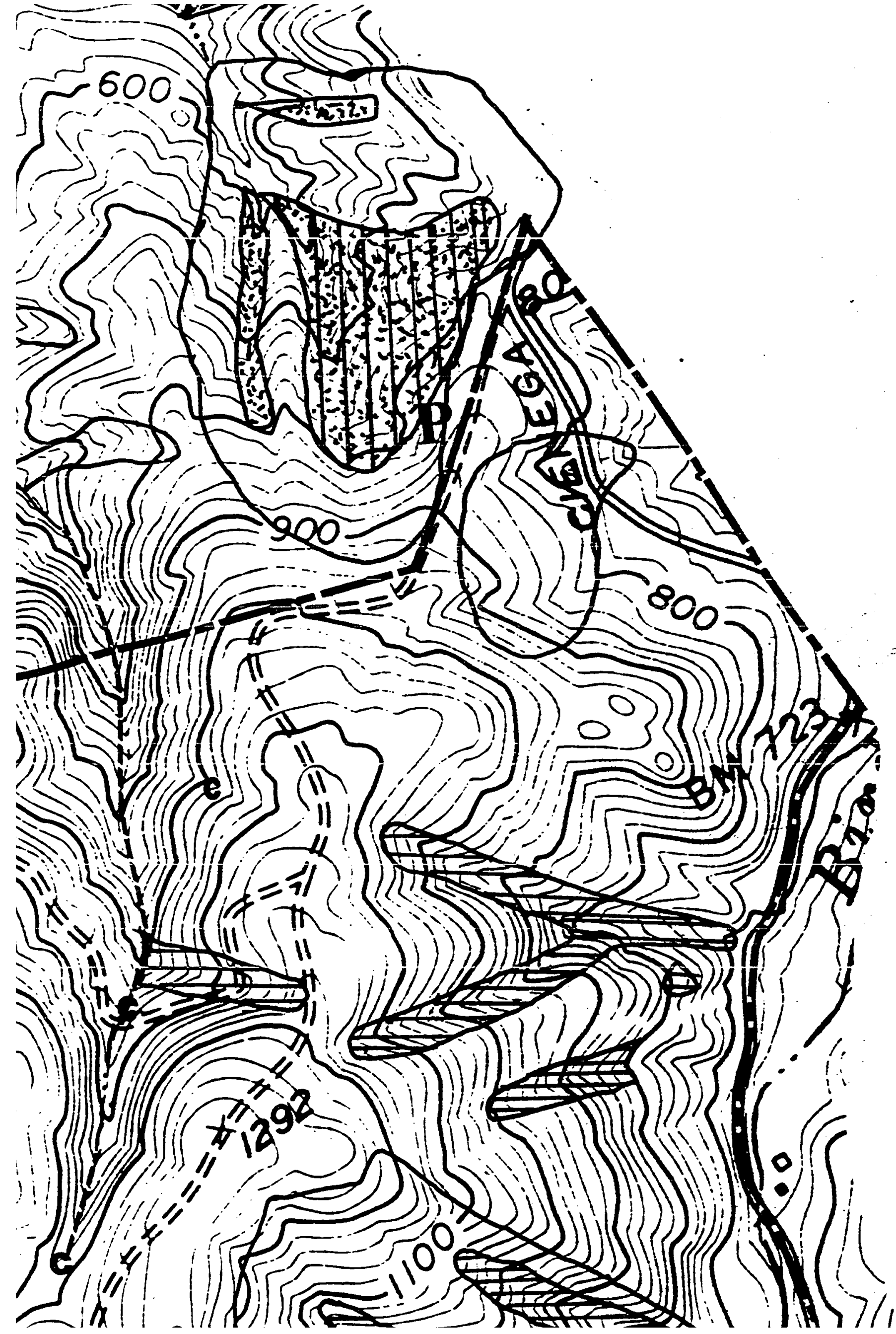




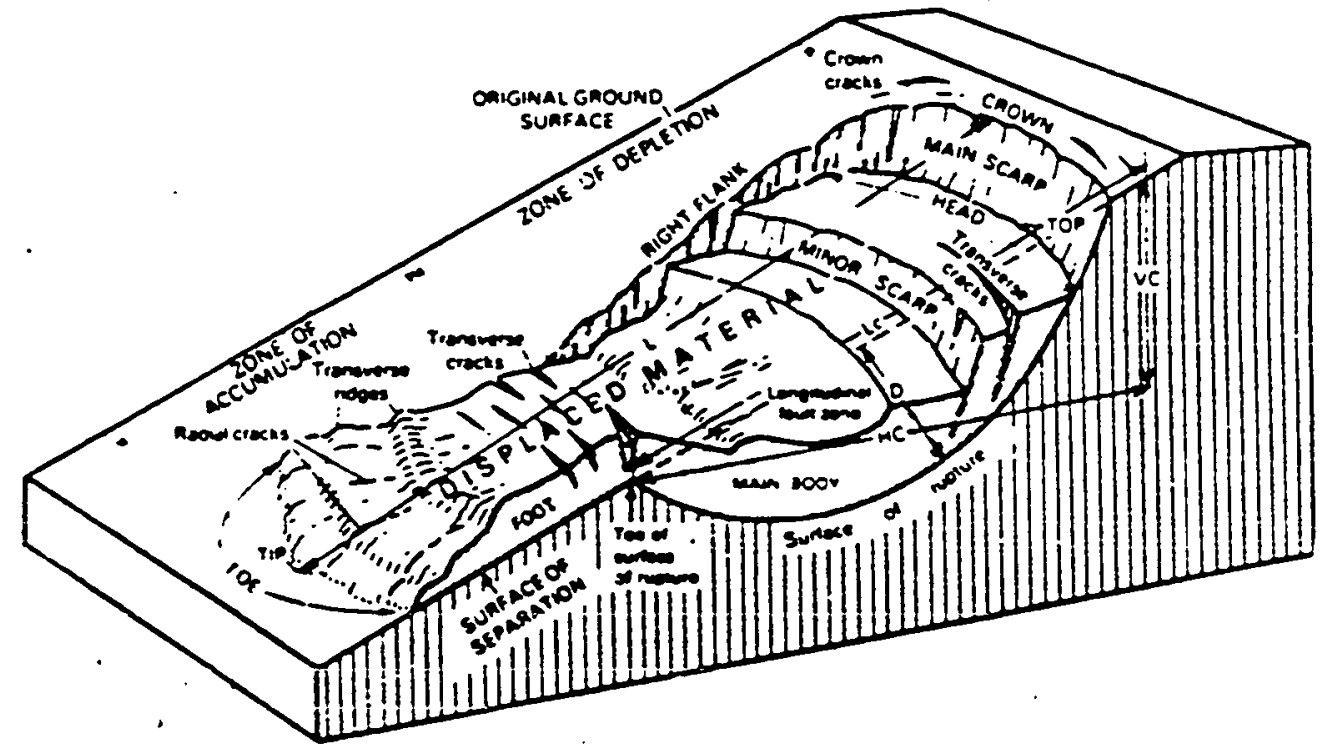

NOMENCLATURE

MaIn SCAkpl-A steep surface on the undisturbed ground around the periphery of the slide. caused by the movement of slide material away from undisturbed ground. The projection of the scarp surface under the displaced material becomes the SLRFACE OF RUPTURE.

Minor sCarp-A steep surface on the displaced material produced by differential movements within the sliding mass.

HEAD-The upper parts of the slide material along the contact between the displaced material and the main scarp.

Top-The highest point of contact between the displaced material and the main scarp.

TOE Of StiRfaCE OF RUPTURE-The intersection (sometimes buried) between the lower part of the surface of rupture and the original ground surface.

TOE-The margin of displaced material most distant from the main scarp.

Tip-The point on the toe most distant from the top of the slide.

Foor-That portion of the displaced material that lies downslope from the toe of the surface of rupture.

Majn sooy-That part of the displaced material that overlies the surface of rupture between the main scarp and toe of the surface of rupture.

FLanx - The side of the landstide.

Crown - The muterial that is still in place, practically undisplaced and adjacent to the highest pars of the main scarp.

Oncomal croumo surface-The slope that existed before the movement which is being considered took place. If this is the surface of an older hadslide, that fact should be stated.

LET ANO RICHT-Compass directions are preferable in dectribing a slide, but if right and left are used they refer to the slide as viewed from the crown.

SURface of SEPARATKon-The surface separating displaced material from stable material bul not known to have been a surface on which failure occurred.

Displaced Material - The material that has moved sway from its original position on the slope. It may be in a deformed or undeformed sate.

ZONE of Dapunon-The area within which the displaced material lies below the or ginal ground surface.

Zone of AccumuLanow-The area within which the displaced material lies above the original ground serface. 


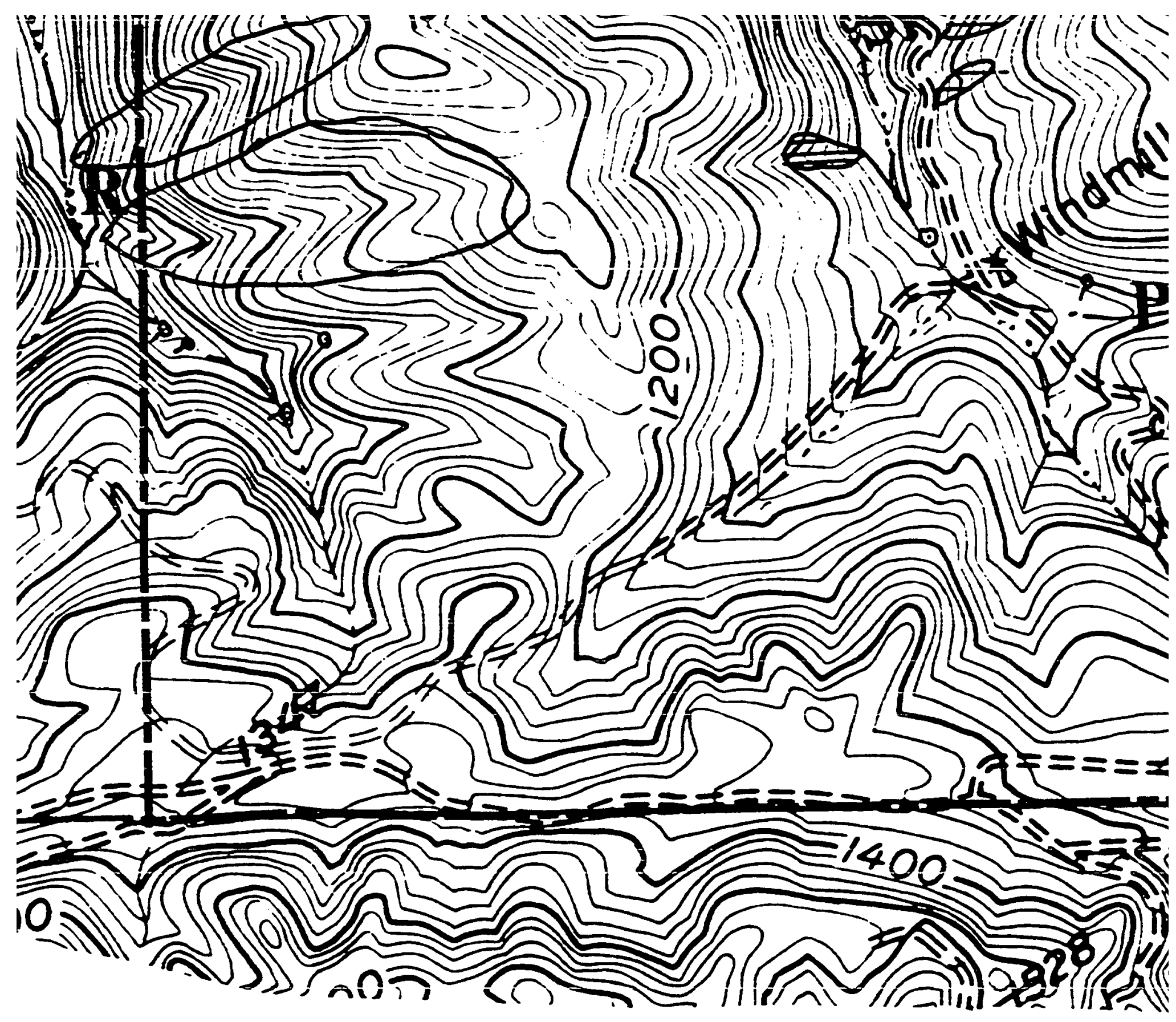




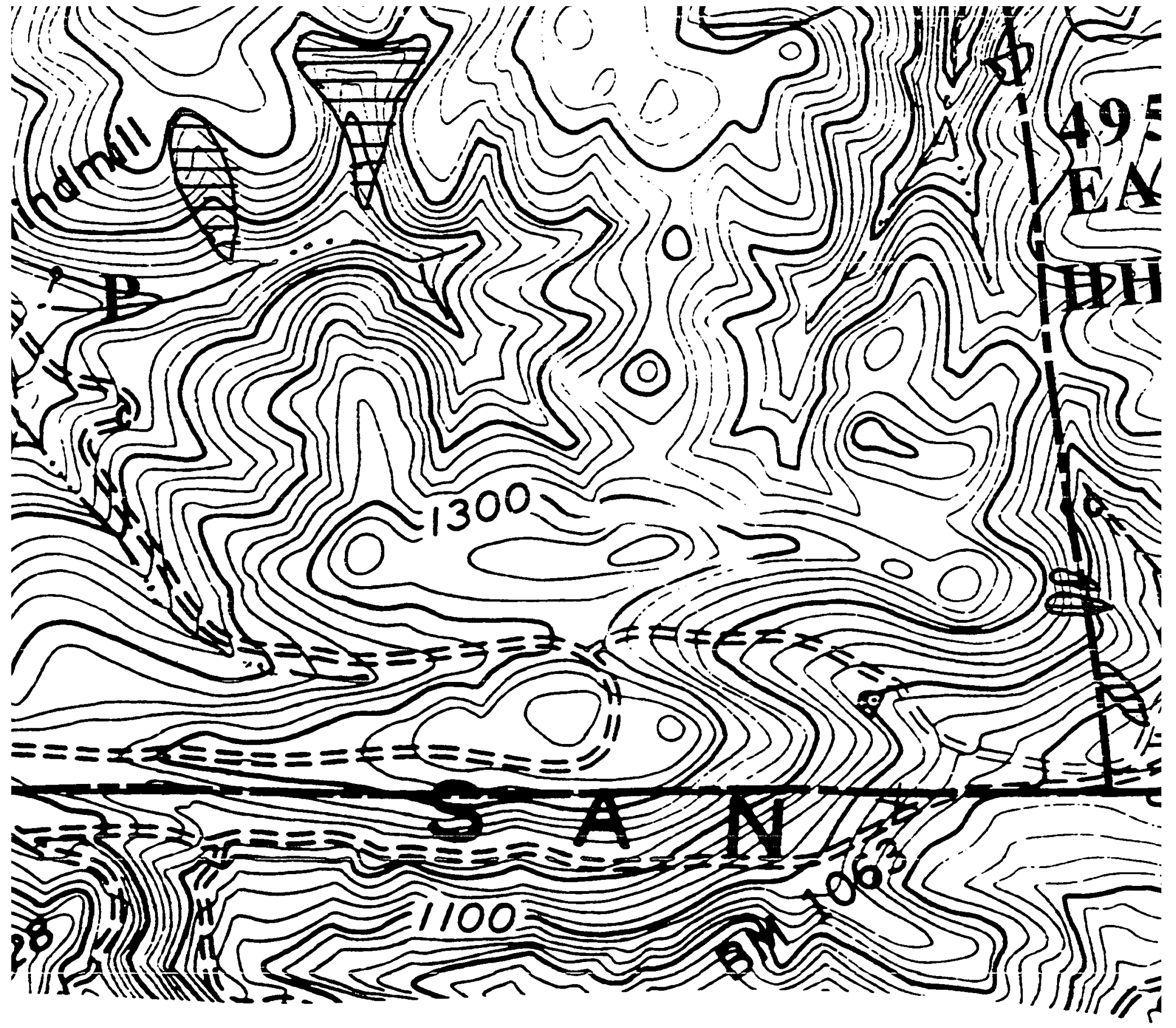

SCALE
$1: 6000$

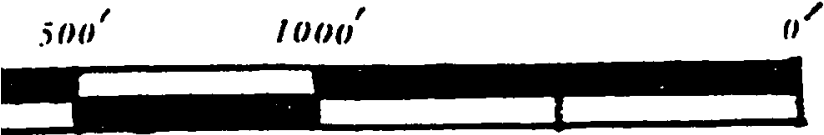




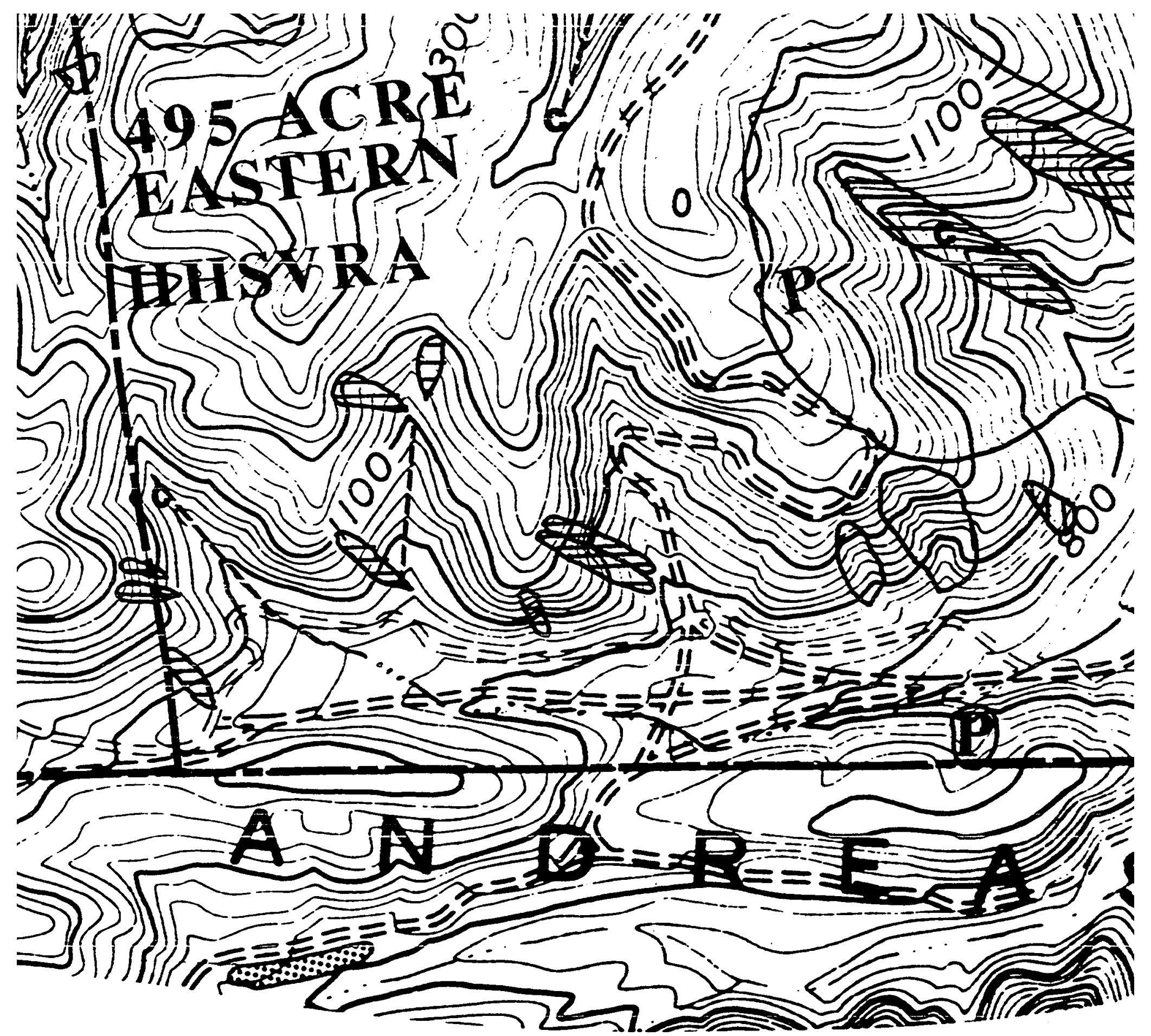




\section{PLEASE NOTE:}

Oversize maps and charts are filmed in sections in the following manner:

\section{LEFT TO RIGHT, TOP TO BOTTOM, WITH SMALL OVERLAPS}

The following map or chart has been refilmed in its entirety at the end of this dissertation (not available on microfiche). A xerographic reproduction has been provided for paper copies and is inserted into the inside of the back cover.

Black and white photographic prints (17" x 23") are available for an additional charge.

\section{University Microfilms International}


- $-1-\ldots-\cdots-\cdots$ 


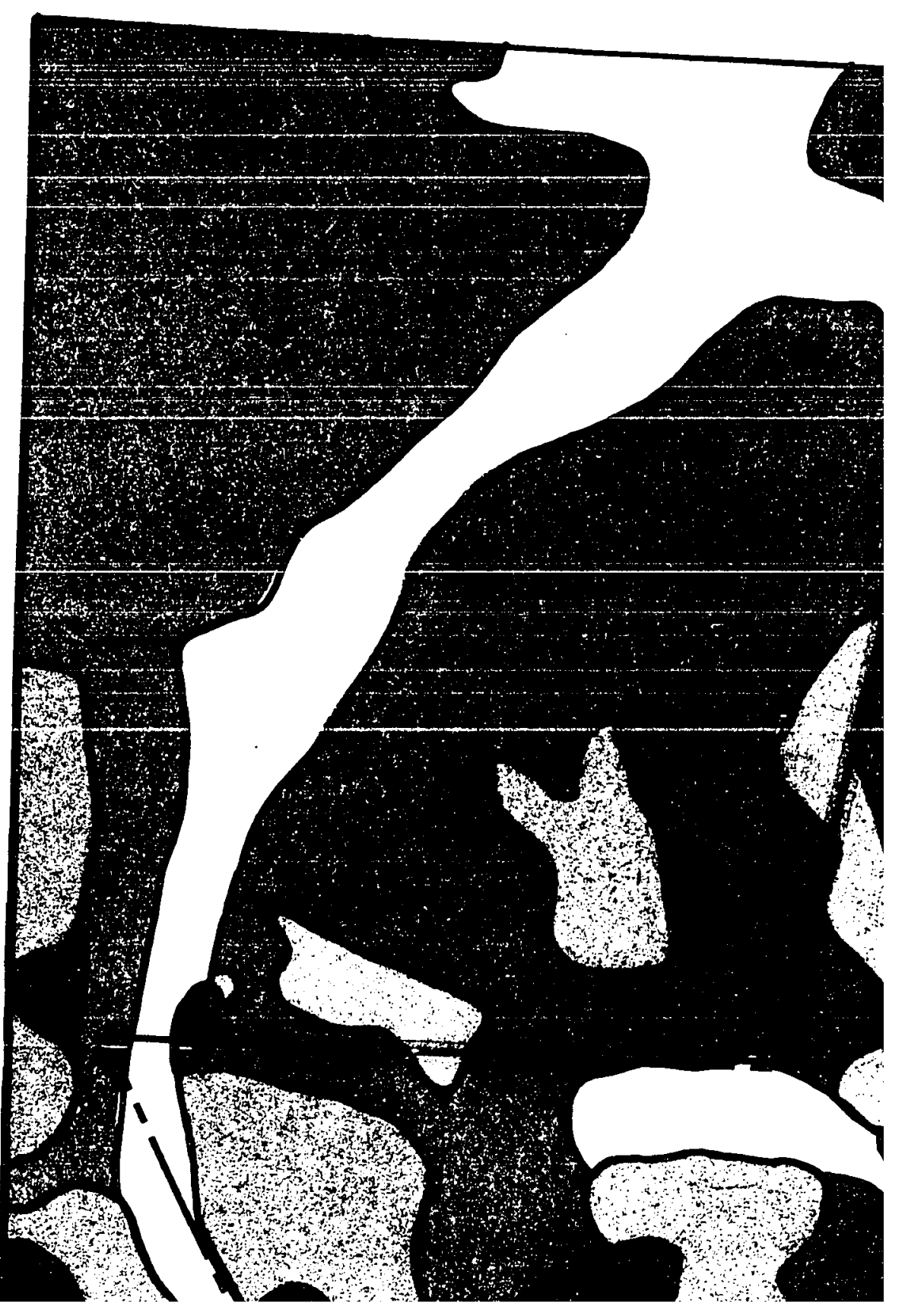




\section{SLOPE MAP OF THE RENZ}

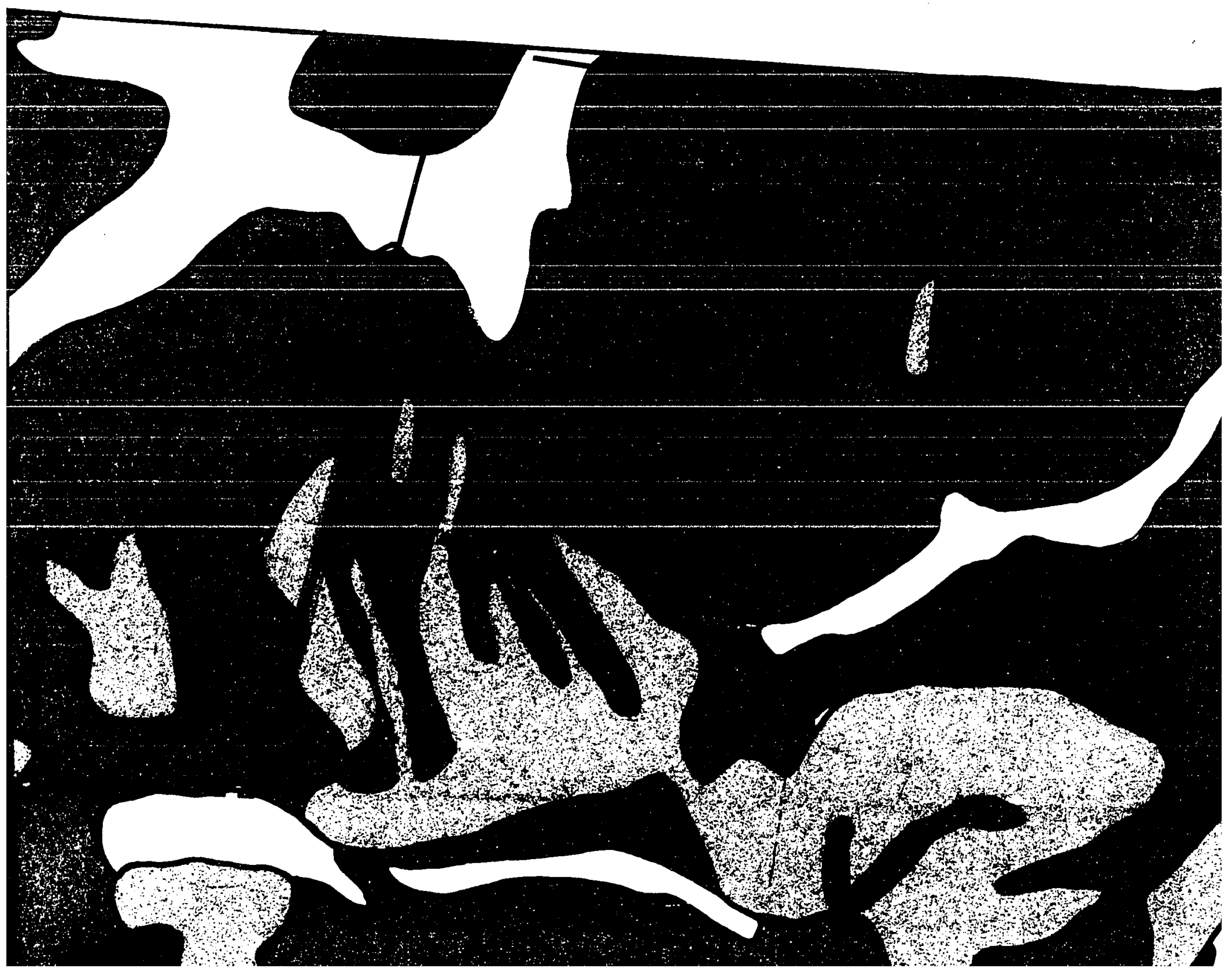


THE RENZ ACQUISITION AND THE EASTERN PORTION OF

BY BRIAN TAYLO

DEPARTMENT OF GEOLOGY, SAN JOSE STAT

1990

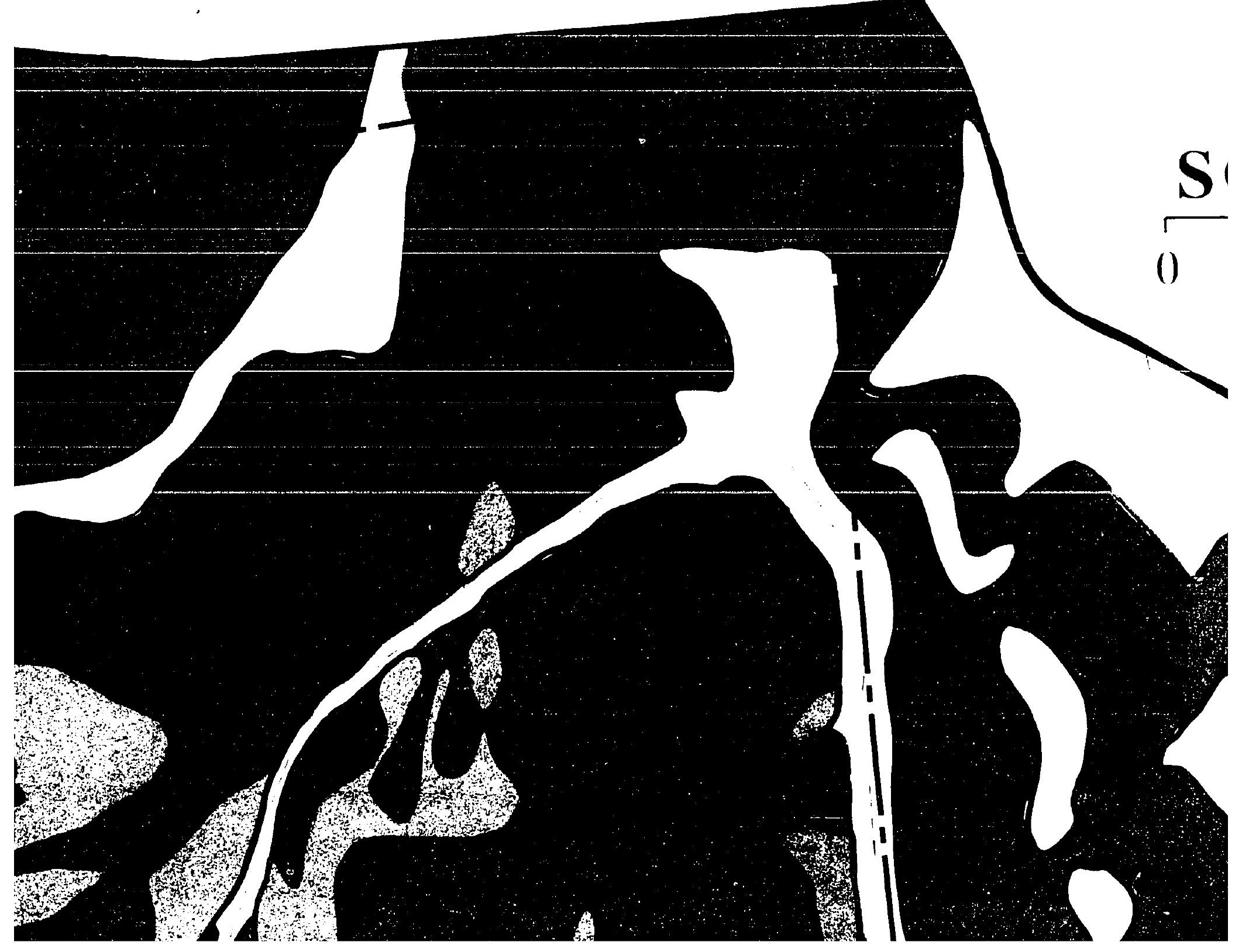


PORTION OF HOLLISTER HILLS STATE RECREATIONAL ARE RIAN TAYLOR

N JOSE STATE UNIVERSITY.

1990

\section{EXPLANAT}

\section{SCALE \\ $0-10 \%$}

$0 \quad 1000 \mathrm{FT}$

$11-30 \%$

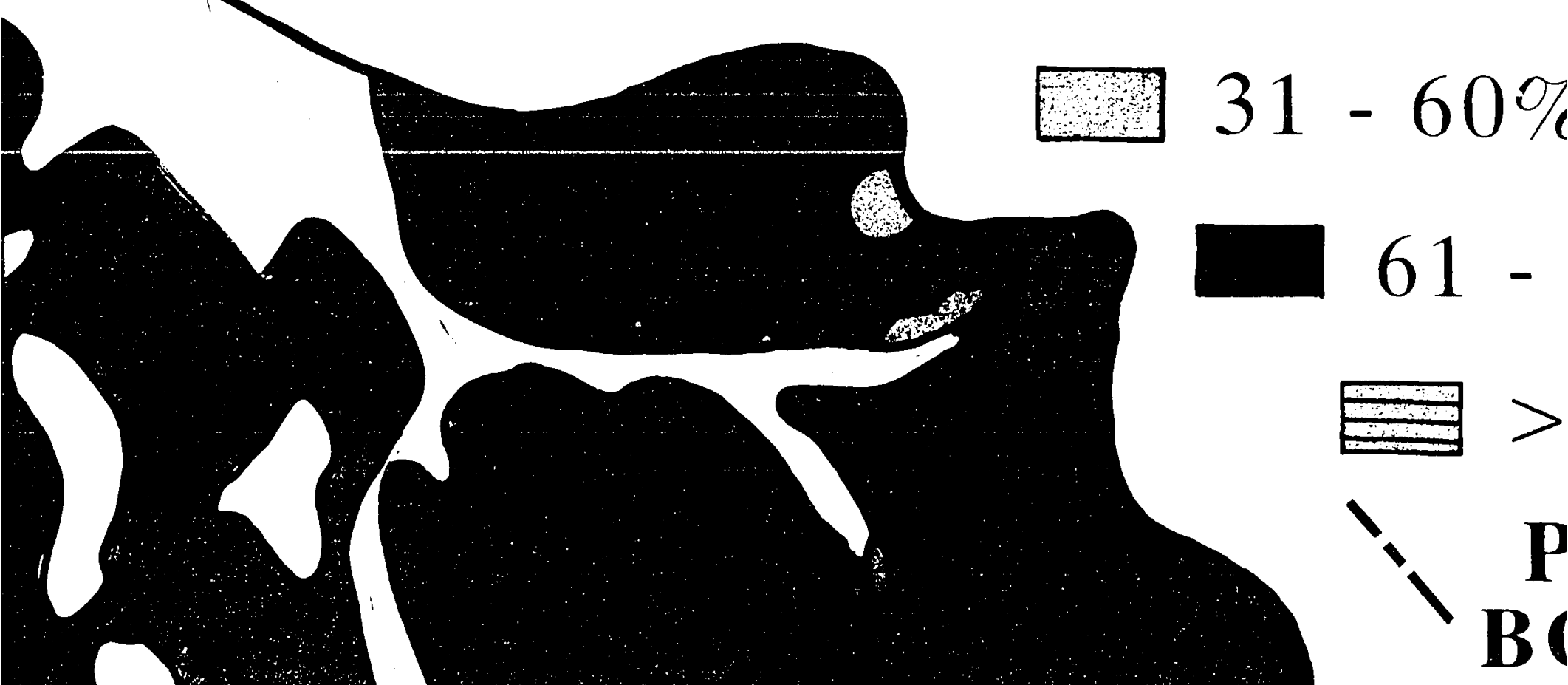


REATIONAL AREA

IPLANATION

j\%

$-30 \%$

$=$

$31-60 \%$

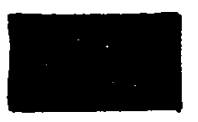

$61-100 \%$

$>100 \%$

Y PROPERTY

BOU NDA R I ES 
plate 2

ON

$100 \%$

$100 \%$

ROPERTY

)U N DA R I ES 


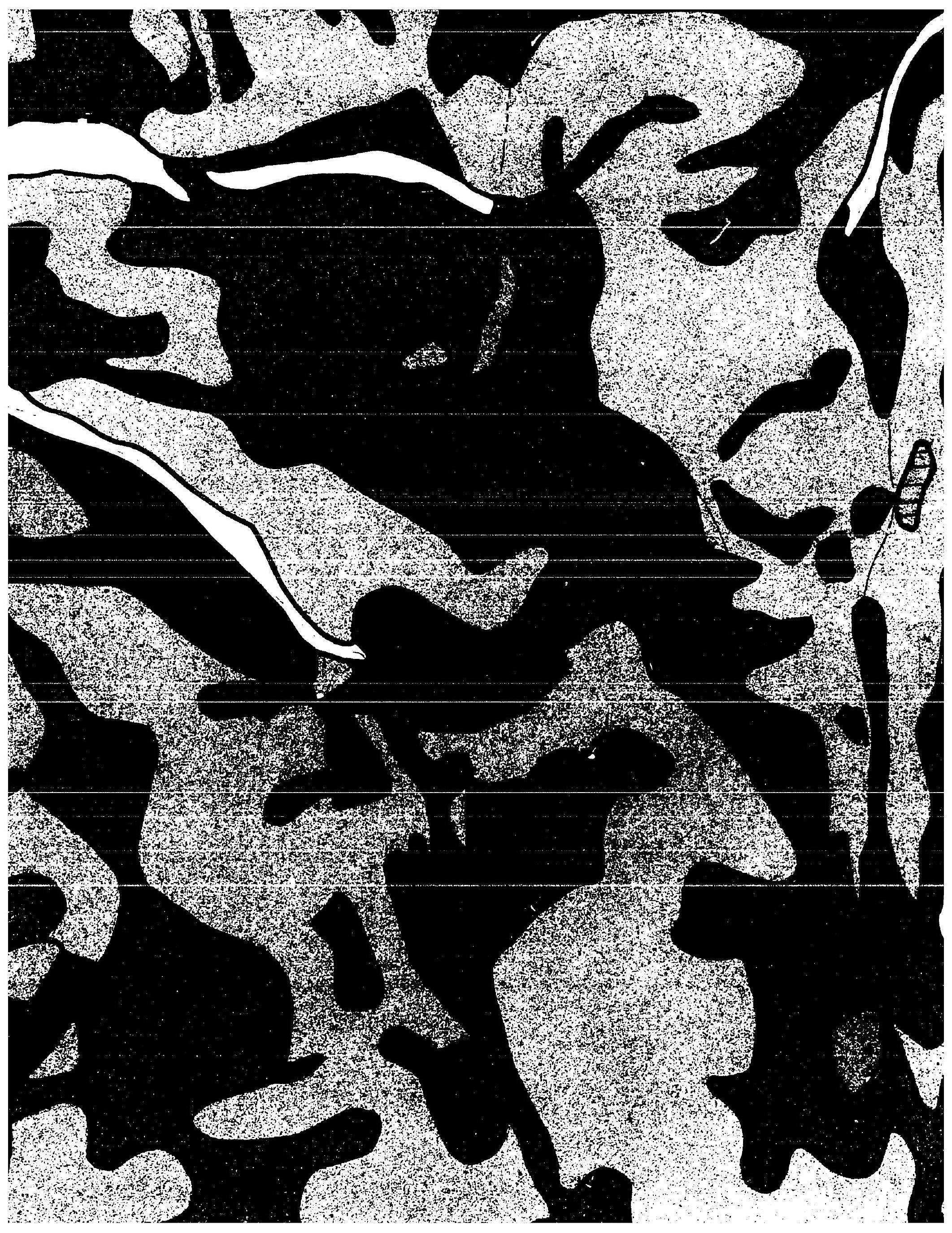




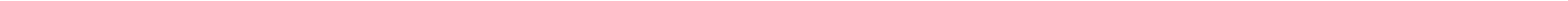




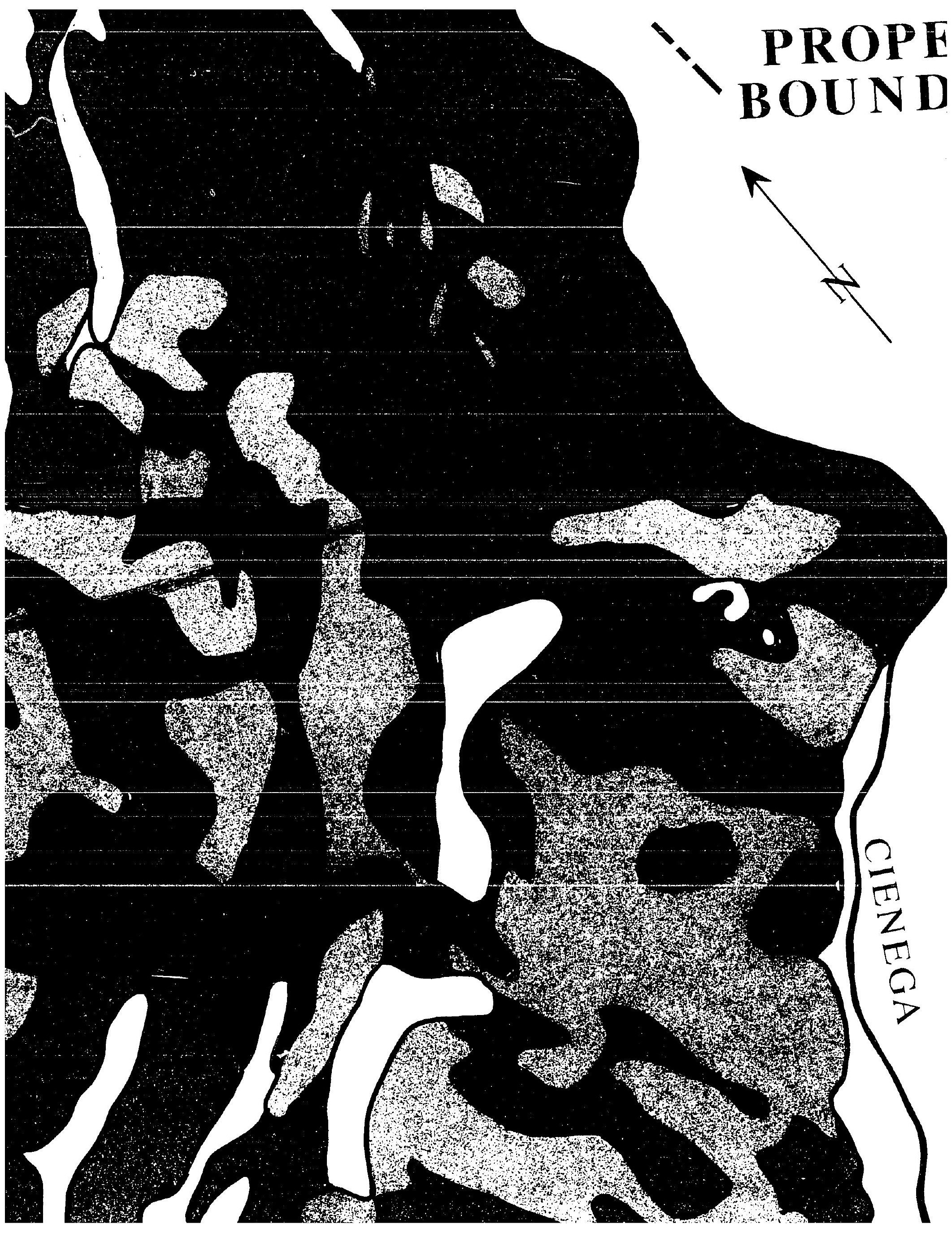


